\author{
University of São Paulo \\ "Luiz de Queiroz" College of Agriculture
}

Strategies to improve kernel processing and dairy cow performance in wholeplant corn silage based on vitreous endosperm hybrid

Gustavo Gonçalves de Souza Salvati

Thesis presented to obtain the degree of Doctor in

Science. Area: Animal Science and Pastures

Piracicaba

2019 
Gustavo Gonçalves de Souza Salvati

Animal Scientist

Strategies to improve kernel processing and dairy cow performance in whole-plant corn silage based on vitreous endosperm hybrid

versão revisada de acordo com a resolução CoPGr 6018 de 2011

Advisor:

Prof. Dr. LUIZ GUSTAVO NUSSIO

Thesis presented to obtain the degree of Doctor in

Science. Area: Animal Science and Pastures

Piracicaba

2019 


\section{Dados Internacionais de Catalogação na Publicação} DIVISÃO DE BIBLIOTECA - DIBD/ESALQ/USP

\section{Salvati, Gustavo Gonçalves de Souza}

Strategies to improve kernel processing and dairy cow performance in whole-plant corn silage based on vitreous endosperm hybrid / Gustavo Gonçalves de Souza Salvati. - - versão revisada de acordo com a resolução CoPGr 6018 de 2011. - - Piracicaba, 2019.

$83 \mathrm{p}$.

Tese (Doutorado)- - USP / Escola Superior de Agricultura "Luiz de Queiroz".

1. Processador de grãos 2. Fibra fisicamente efetiva 3. Endosperma vítreo 4. Digestibilidade de amido I. Título 
"We are the average of the five people we spend the most time with" Jim Rohn 


\section{ACKNOWLEDGMENTS}

First of all, I thank God for giving me the gift of life and for all the people he has put in my way.

To my parents, José Augusto and Ceyla Maria, for being my example of extraordinary human beings. They always taught me to help others, and motivated me to follow my dreams and to be the best version of myself.

To my brothers, Priscila and Igor, for all the support and for sharing happy moments.

To my girlfriend, Renata, who supported me in every step of this project with patience and kindness.

To my friends from the Forage Quality and Conservation Group - QCF, for the fellowship, the help during the stages of this work and for good moments of enjoyment.

To the Department of Animal Science's employees, who collaborated to this project and with whom I also shared moments of enjoyment.

To my advisor, Dr. Luiz Gustavo Nussio, for his contribution to my professional training through his instructions and opportunities during my $\mathrm{PhD}$ training.

To "Luiz de Queiroz" College of Agriculture, Animal Science and Pastures Graduate Program, and the faculty team for the opportunity and supportduring my $\mathrm{PhD}$ training.

To FAPESP (The State of São Paulo Research Foundation) for my scholarship and financial support.

To CAPES foundation for the my first scholarship

To Cargill for the donation of SoyPass ${ }^{\circledR}$, Nutricorp for calcium soap of palm fatty acids, Adisseo for Smartamine-M and Phileo-Lessafre for Procreatin7.

To support of TQR Agro, New Holland, Jumil and JF Máquinas during the harvest of the treatments.

To Dr. Marcos Neves Pereira, for the contribution to my professional training when I was an undergraduate student, and during my master's degree. Also, for accepting to join my committee.

To Dr. Luiz Felipe Ferraretto, for his instructions during my international training at the University of Wisconsin-Madison in 2014, a factor that contributed to the elaboration of this project and to my professional training.

To Dr. João Luiz Pratti Daniel, for the intellectual contribution in my training during graduation. 
To Dr. Nilson Nunes Morais Júnior and his team for the contribution in the execution of experiment 2 and in the starch analyzes of the other experiments.

To all my friends who shared this challenge with me. Especially Willian, who has been my good friend since we were undergraduate students, your partnership was very important during these last years.

To my English teacher, Lise, for corrections and friendship.

To my family, for giving me the opportunity to discover my gift of working with dairy cows at the farm in Bom Jesus do Itabapoana-RJ.

To my grandparents (José Salvato in memmorian, Nadyr, José Alves and Zenilda) and my great-grandmother (Idete) for unconditional support.

To my friend Diego Albino Lopes, in memmorian. 


\section{CONTENTS}

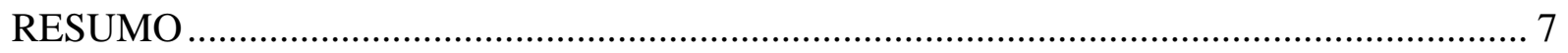

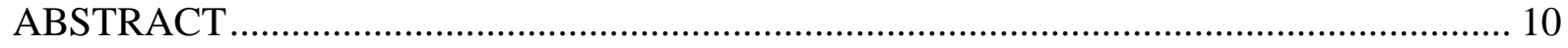

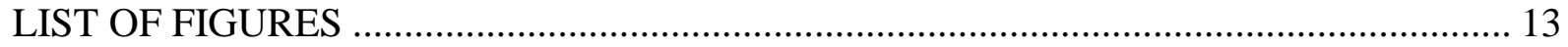

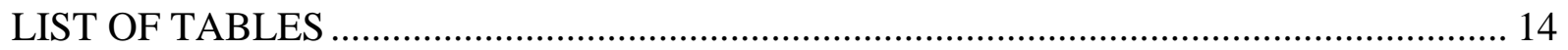

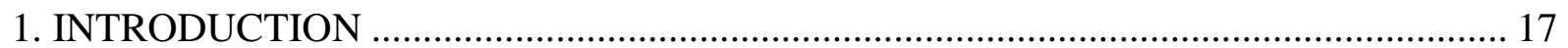

2. STRATEGIES TO MAXIMIZE KERNEL PROCESSING IN BRAZILIAN VITREOUS

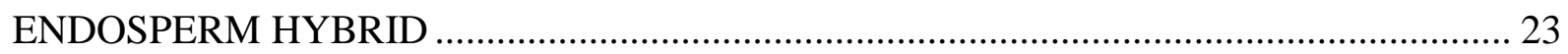

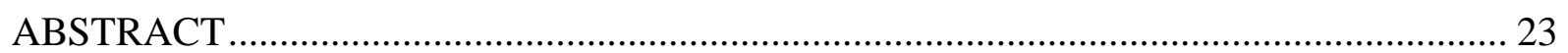

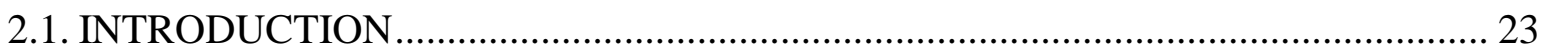

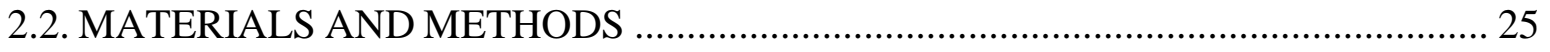

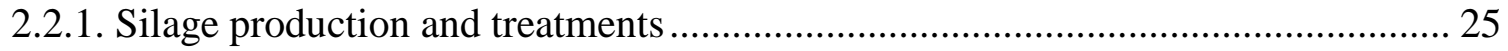

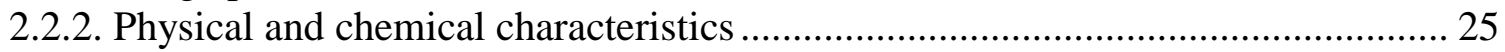

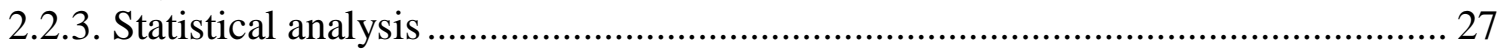

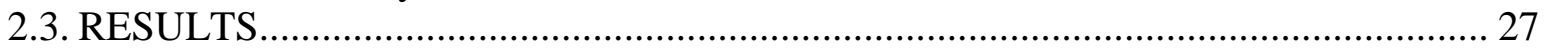

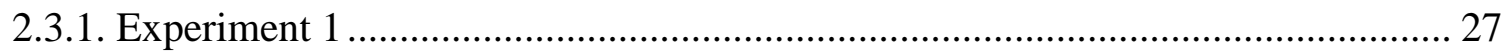

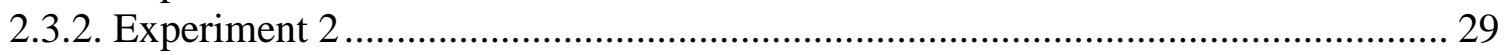

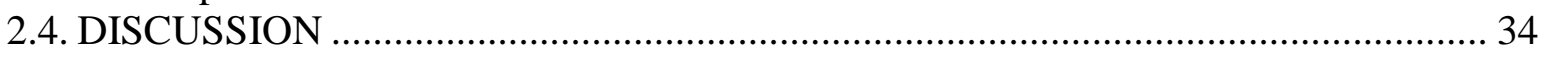

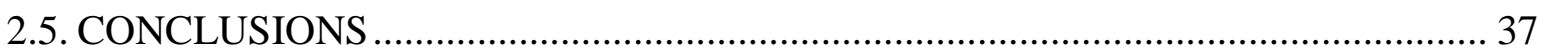

3. HOW DOES A NOVEL PULL-TYPE FORAGE HARVESTER WITH KERNEL

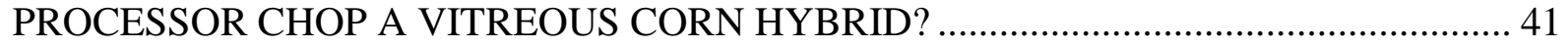

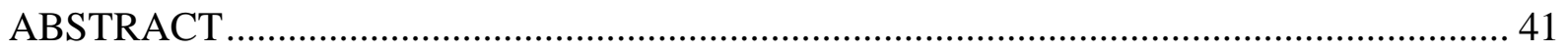

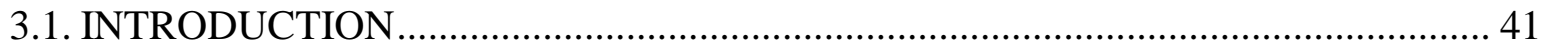

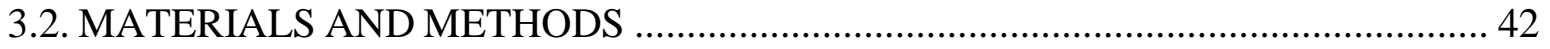

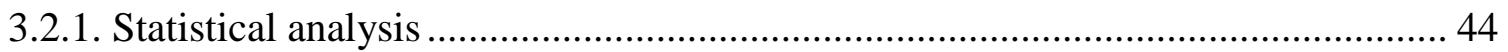

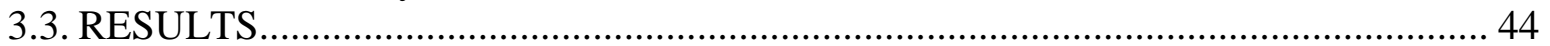

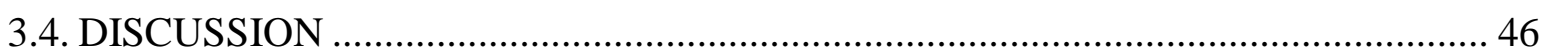

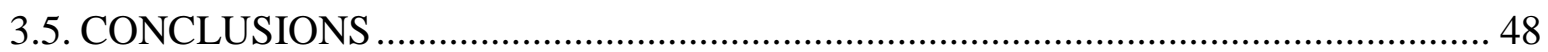

4. IMPACT OF KERNEL PROCESSING AND PARTICLE SIZE IN WHOLE PLANT CORN SILAGE WITH VITREOUS ENDOSPERM ON DAIRY COW PERFORMANCE 51

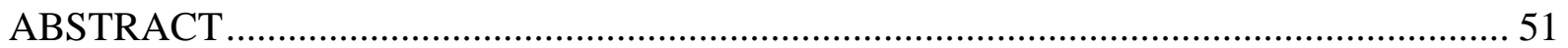

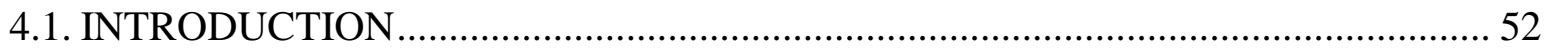

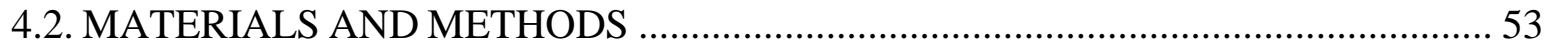

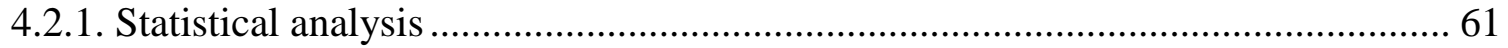

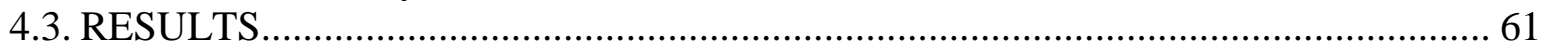

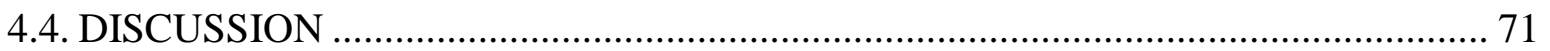

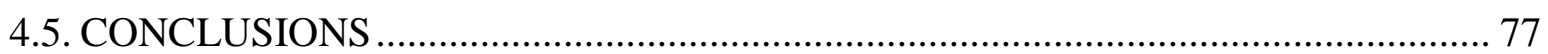

LITERATURE CITED ............................................................ 77 


\section{RESUMO}

\section{Estratégias para melhorar o processamento de grãos e o desempenho de vacas leiteiras} em silagem de planta inteira de milho oriunda de híbrido de endosperma vítreo

Silagem de milho (SM) é a principal fonte de forragem para vacas leiteiras em sistemas intensificados de produção no Brasil. O processamento adequado dos grãos é crucial principalmente quando SM são oriundas de híbridos com endosperma vítreo, os quais são mais difíceis de serem quebrados. Nesse sentindo dois experimentos foram conduzidos para avaliar os efeitos do tamanho teórico de corte (TTC) e do tempo de estocagem sobre o tamanho de partículas e o processamento dos grãos em SM colhida com diferentes tipos de colhedoras. O mesmo híbrido de milho vítreo DKB 177 VT PRO 2 foi usado em ambos os experimentos. A média do teor de matéria seca da planta no momento da colheita foi de $34,2 \%$. No primeiro experimento, a lavoura de milho foi colhida por uma colhedora de forragem tracionada por trator (CFTT; JF AT 1600, sem processador de grãos) nos TTC de 3, 6 e 9-mm. No segundo experimento, a colheita foi realizada por uma colhedora de forragem auto propelida (CFAP; New Holland, FR 9050) nos seguintes TTC: 6, 12 e 18-mm com distância entre os rolos de 3$\mathrm{mm}$. As SM foram armazenadas em mini-silos (4 repetições por tratamento) por 0 , 35 e 140 dias. A vitreosidade foi medida por dissecação em grãos não fermentados e foi de $65,6 \%$. Os dados de ambos os ensaios foram analisados como arranjo em parcelas subdivididas usando o procedimento MIXED do SAS (SAS Institute Inc., Cary, NC). O modelo incluiu os efeitos fixos do TTC, tempo de estocagem e a interação entre os mesmos. Na CFTT, os TTC de 3 e 6-mm não impactaram na distribuição das partículas e no tamanho médio de partículas (TMP). No entanto, o TTC de 9-mm aumentou a porcentagem de partículas acima das 2 peneiras superiores do separador de partículas da Penn State e consequentemente, o TMP. O aumento do TTC na CFAP levou a aumento da porcentagem de partículas longas (> 19-mm) e do TMP. O tempo de estocagem também aumentou porcentagem de partículas longas e TMP apenas para SM colhida por CFAP. A estratégia de redução de TTC na CFAP melhorou a porcentagem de grãos menores que 4,75-mm. Além disso, o TTC de 6-mm proporcionou o melhor processamento de grãos nesta mesma colhedora. O tempo de estocagem reduziu o tamanho de partículas da fração grãos para ambas as colhedoras. O corn silage processing score (CSPS) aumentou apenas após 140 dias de estocagem somente para as amostras colhidas por CFAP. No terceiro experimento, o objetivo foi avaliar o efeito de uma CFTT equipada com processador de grãos (PG) regulado em diferentes tamanhos de corte sobre características físicas de SM. Um híbrido de endosperma vítreo (BM 709, Sementes Biomatrix) foi cultivado e colhido quando a MS da planta de milho atingiu 34,8\%. A plantação foi colhida com uma CFTP sem PG regulada para TTC de 6 e 10-mm ou por uma CFTP com PG ajustada para os mesmos TTC. As amostras de SM foram armazenadas por 35 dias. A vitreosidade foi de 62,4\%. Os dados foram analisados em delineamento inteiramente casualizado em arranjo fatorial: 2 tipos de colhedoras $\times 2$ TTC utilizando o procedimento MIXED da SAS (SAS Institute Inc., Cary, NC). O modelo incluiu os efeitos fixos de colhedora, do TTC e da interação dos mesmos. As seguintes diferenças ocorreram 
apenas no TTC de 10-mm. O PG reduziu o material retido acima da peneira de crivo de $19 \mathrm{~mm}$ de 4,7 para $1,8 \%$, o que por sua vez aumentou a percentagem de partículas abaixo da peneira de crivo de $8-\mathrm{mm}$ e diminuiu o TMP. Este TTC exibiu o valor mais alto de material retido na peneira de $8-\mathrm{mm}$ e os valores mais baixos na peneira de $4 \mathrm{~mm}$ para SM não processada. Tanto o processamento de grãos e como a redução do TTC levaram a um aumento de partículas retidas na peneira de $4 \mathrm{~mm}$. O PG aumentou a porcentagem de grãos menores que $4,75 \mathrm{~mm}$ de 56,4 para 80,0\% e o teor de amido abaixo da peneira de 8-mm. O TTC de 6mm e o PG levaram a uma redução do tamanho geométrico dos grãos, com subsequente aumento da área superficial. A nova CFTT com PG promoveu um processamento mais intenso nos grãos. No quarto experimento, os objetivos do estudo foram: 1) avaliar o efeito do processamento de grãos em um híbrido brasileiro de endosperma vítreo e 2) aumento no tamanho de partículas da SM no consumo, desempenho, digestibilidade dos nutrientes, comportamento alimentar e perfil de ácidos graxos no leite de vacas leiteiras. Os seguintes tratamentos foram realizados durante a colheita: 1) CFTT (sem PG, JF AT 1600) ajustada para um TTC de 6-mm - PT6; 2) CFAP (New Holland, FR 9050) ajustada para um TTC de 6-mm - SP6; 3) CFAP ajustada para um TTC de 12-mm - SP12; e 4) CFAP ajustada para um TTC de 18-mm -SP18. As SM foram estocadas por 9 meses. Os CSPS das SM dos tratamentos foram: 32,1\% (PT6), 53,9\% (SP6), 49,0\% (SP12) e 40,1 (SP18). Vinte e quatro vacas da raça Holandesa (139 \pm 63 DEL) foram blocadas e distribuídas em seis quadrados latinos $4 \times 4$, com período de 24 dias (18 dias de adaptação). As dietas foram formuladas para conter (\% MS) 48,5\% SM, 9,5\% farelo de soja, 6,9\% farelo de soja protegido, 15,1\% milho moído seco, $15,5 \%$ polpa cítrica, $1,7 \%$ de minerais e vitaminas, $1,8 \%$ de sabão de cálcio de ácidos graxos de palma e $1 \%$ de ureia. A composição nutricional das dietas (\% MS) foi: $16,5 \% \mathrm{~PB}, 28,9 \%$ FDN e $25,4 \%$ amido. Três contrastes ortogonais foram usados para comparar os tratamentos: $\mathrm{C}_{1}=$ PT6 vs. SP6 (efeito do processamento de grãos), $\mathrm{C}_{2}=$ SP6 vs. SP12 (efeito do tamanho de partículas) e $\mathrm{C}_{3}=\mathrm{SP} 12$ vs. SP18 (efeito do tamanho de partículas). Vacas alimentadas com SP6 apresentaram maior produção de leite de $1,2 \mathrm{~kg} / \mathrm{d}$, sem alterações no consumo de matéria seca, resultando em maior eficiência alimentar quando comparadas com PT6. A digestibilidade do amido no trato total e a glicose plasmática também foram maiores para as vacas alimentas com SP6. Além disso, as maiores secreções de proteína (+ $36 \mathrm{~g} / \mathrm{d})$, lactose $(+61 \mathrm{~g} / \mathrm{d})$ e sólidos do leite $(+94 \mathrm{~g} / \mathrm{d})$ foram resultado da melhora na produção de leite para as vacas do SP6. O mecanismo envolve uma melhor digestibilidade dos nutrientes e disponibilidade de glicose para a síntese de lactose pela glândula mamária. Não houve evidência de diferenças no consumo de matéria seca $(\mathrm{kg} / \mathrm{d})$ entre os tratamentos colhidos por SPFH. As vacas do SP12 alcançaram a mesma produção de leite em relação ao SP6; no entanto, elas tenderam a reduzir a concentração plasmática de D-lactato e o amiloide sérico A (SAA), maximizando o tempo de mastigação e selecionando a favor de partículas finas. No SP6, vacas selecionaram contra partículas finas e tenderam a aumentar SAA em relação a PT6. O SP18 reduziu a digestibilidade do amido no trato total e tendeu a reduzir a produção de leite e a glicose plasmática. O SP6 elevou o teor de ácidos graxos da cadeia linear ímpar do leite em comparação ao PT6. No entanto, uma redução desses mesmos ácidos graxos ocorreu no SP12 em relação ao SP6. As vacas SP6 apresentaram maior teor de alguns ácidos graxos monoinsaturados (C14:1 e C16:1), porém o oposto ocorreu para SP12. O processamento de grãos nos TTC de 6 e 12-mm aumentou a digestibilidade de amido, glicose plasmática e 
produção de leite, enquanto o TTC de 18 -mm prejudicou o desempenho e a digestibilidade de amido. O TTC de 12-mm melhorou o tempo de mastigação e reduziu os marcadores de acidose subclínica no sangue. Estes resultados sugerem que o tempo de estocagem de pelo menos 140 dias e TTC curto (6-mm) para SPFH podem ser estratégias para maximizar o processamento de grãos e, assim, a digestibilidade do amido em SM. Porém, para promover desempenho e saúde de vacas leiteiras, o TTC de 12-mm é o indicado para colheita de híbridos de milho endosperma vítreo para SM.

Palavras-chave: Endosperma vítreo; Tempo de estocagem; Processamento de grãos; Tamanho teórico de corte; Digestibilidade de amido 


\title{
ABSTRACT \\ Strategies to improve kernel processing and dairy cow performance in whole-plant corn

\author{
silage based on vitreous endosperm hybrid
}

\begin{abstract}
Whole-plant corn silage (WPCS) is a major source of forage for lactating dairy cattle in Brazil. Improved kernel processing may be especially advantageous when feeding corn hybrids with vitreous endosperm, which are more difficult to be broken. Two experiments were conducted to evaluate the effects of theoretical length of cut (TLOC) and ensiling time on whole-plant corn silage (WPCS) particle size and kernel processing with two types of forage harvesters. The same vitreous corn hybrid DKB 177 VT PRO 2 was used in both experiments. In the first experiment, the whole-plant corn was harvested by a pull-type forage harvester (PTFH) at TLOC of 3, 6 and 9-mm. In the second experiment, the harvesting was performed by a self-propelled forage harvester (SPFH) at the following TLOC settings: 6, 12 and 18-mm with a roll gap of 3-mm. The WPCS were stored for 0,35 and $140 \mathrm{~d}$. Vitreousness, measured by dissection in unfermented kernels, averaged $65.6 \%$. Data from both trials were analyzed as a split-plot design using the procedure MIXED of SAS (SAS Institute Inc., Cary, NC). The model included the fixed effects of TLOC, ensiling time and the interaction TLOC $\times$ ensiling time. In PTFH, the TLOC of 3 and 6-mm did not differ WPCS particle size distribution and mean particle length (MPL). However, the TLOC of 9-mm increased particles above the top 2 sieves and, as a consequence, the MPL. The rise of TLOC in SPFH led to a higher MPL and percentage of long particles (> 19-mm). The ensiling time increased MPL and long particles only for WPCS harvested by SPFH. The strategy of reducing TLOC in SPFH increased the percentage of kernels smaller than 4.75-mm. Furthermore, The TLOC of 6-mm led to the best kernel processing for SPFH. The ensiling time reduced the particle size of kernel fraction for both forage harvesters. The corn silage processing score only improved with $140 \mathrm{~d}$ of ensiling for SPFH samples. In the third experiment the objective was to evaluate the impact of two types of forage harvesters and two TLOC settings on the physical characteristics of WPCS. A vitreous corn silage hybrid (BM 709, Sementes Biomatrix) was cultivated and harvested when whole-corn plant DM achieved 34.8\%. The whole-plant was harvested with a conventional pull-type forage harvester (PTFH) without kernel processor (KP) at 6 and 10 of theoretical lengths of cut (TLOC) or by a new PTFH with KP at same TLOC settings. Whole-plant corn silage (WPCS) samples were stored for $35 \mathrm{~d}$. Vitreousness, measured by dissection in unfermented kernels, averaged $62.4 \%$. Data were analyzed as completely randomized design in a factorial arrangement: 2 harvesters $\times 2$ TLOC using the procedure MIXED of SAS (SAS Institute Inc., Cary, NC). The model included the fixed effects of harvester, TLOC and the interaction harvester $\times$ TLOC. The major differences occurred only in TLOC of $10-\mathrm{mm}$. KP reduced the material above the $19-\mathrm{mm}$ sieve from 4.7 to $1.8 \%$ which, in turn, increased the percentage of particles below 8 -mm sieve while MPL was decreased. This TLOC displayed the highest value of material retained in the $8-\mathrm{mm}$ and the lowest values in the 4-mm sieve for unprocessed WPCS. Kernel processing and short TLOC led to a rise in particles retained in a 4-mm sieve. KP increased the percentage of kernels smaller than
\end{abstract}


4.75-mm from 56.4 to $80.0 \%$ and the starch content below $8-\mathrm{mm}$ sieve. The short TLOC and kernel processing, together, led to a reduction of kernel geometrical mean particle size (GMPS) followed by an increase of surface area. The new PTFH with KP promoted more extensive and effective kernel breakage. The impact of this harvester in WPCS particle size distribution was pronounced in the TLOC of 10-mm which led to a drop in MPL. The reduction of TLOC for both forage harvesters may be a good strategy to fracture corn kernels for WPCS at $34.8 \%$ of DM. In the fourth experiment, the objectives of this study were: 1) to evaluate the effect of kernel processing on a Brazilian vitreous endosperm corn hybrid and 2) the increment of particle size in WPCS on intake, lactation performance, total-tract nutrient digestibility, feeding behavior and milk fatty acids profile. The following treatments were performed during the harvest: 1) pull-type forage harvester (without kernel processor, JF AT 1600) set for a 6-mm theoretical length of cut (TLOC) - PT6; 2) self-propelled forage harvester (New Holland, FR 9050) set for a 6-mm TLOC - SP6; 3) self-propelled forage harvester set for a 12-mm TLOC - SP12; and 4) self-propelled forage harvester set for a 18$\mathrm{mm}$ TLOC - SP18. The WPCS of treatments were storaged for 9 months. The CSPS of the WPCS were: $32.1 \%$ (PT6), 53.9\% (SP6), 49.0\% (SP12) and 40.1\% (SP18). Holstein cows $(\mathrm{n}=24 ; 139 \pm 63$ DIM) were blocked and assigned to six 4 $\times 4$ Latin squares, with 24-d period (18 d of adaptation). Diets were formulated to contain (\% DM) 48.5\% WPCS, 9.5\% soybean meal, 6.9\% soybean meal nonenzymatic browned, $15.1 \%$ dry ground corn, $15.5 \%$ citrus pulp, $1.7 \%$ minerals and vitamins mix, $1.8 \%$ calcium soap of palm fatty acids, and $1 \%$ urea. Nutrient composition of the diets (\% DM) was: $16.5 \% \mathrm{CP}, 28.9 \% \mathrm{NDF}$ and $25.4 \%$ starch. Three orthogonal contrasts were used to compare treatments: $\mathrm{C}_{1}=$ PT6 vs. SP6 (effect of kernel processing), $\mathrm{C}_{2}=\mathrm{SP} 6$ vs. SP12 (effect of particle size) and $\mathrm{C}_{3}=$ SP12 vs. SP18 (effect of particle size). Cows fed SP6 WPCS had greater $1.2 \mathrm{~kg} / \mathrm{d}$ milk yield with no changes in DMI, resulting in greater feed efficiency when compared with PT6. The total-tract starch digestibility (TTSD) and plasma glucose was also improved when cows were fed SP6. Moreover, the higher milk protein $(+36 \mathrm{~g} / \mathrm{d})$, lactose $(+61 \mathrm{~g} / \mathrm{d})$ and solids $(+94 \mathrm{~g} / \mathrm{d})$ secretions were a result of the improvement in milk yield for SP6. In addition, the mechanism apparently involved a better nutrient digestibility and glucose availability for the synthesis of lactose by the mammary gland. There was no evidence for differences in DMI $(\mathrm{kg} / \mathrm{d})$ among self-propelled treatments. The SP12 cows achieved the same milk yield of SP6; however they tended to reduce plasma D-lactate and serum amiloyd A (SAA) while maximizing chewing time and selecting for fine particles. In SP6, cows selected against fine particles and tended to show higher levels of SAA than PT6. The SP18 reduced TTSD and tended to reduce milk production, and plasma glucose. The SP6 raised milk linear-odd chain fatty acids content in comparison with PT6. Nonetheless, a reduction of these same fatty acids occurred in SP12 in relation to SP6. SP6 cows had higher content of some monounsaturated fatty acids (C14:1 and C16:1), however the opposite occurred for SP12. Kernel processing at TLOC settings of 6 and 12-mm enhanced nutrient digestibility, plasma glucose and milk yield, whereas the 18-mm TLOC impaired lactation performance and TTSD. The TLOC of 12-mm improved chewing time and reduced blood subacute acidotic markers. The findings of this set of studies suggest that ensiling time and low TLOC in SPFH (6-mm) may be strategies to increase kernel damage and thus starch digestibility in WPCS. Despite 6-mm TLOC has improved kernel 
processing, the TLOC of 12-mm appeared to be the best setting to harvest wholecorn plant to feed dairy cows.

Keywords: Vitreous endosperm; Ensiling time; Kernel processing; Theoretical length of cut; Starch digestibility 


\section{LIST OF FIGURES}

Figure 1. Interaction between TLOC and ensiling time for particles in the Penn State

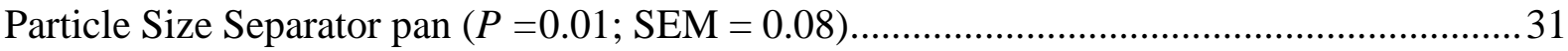

Figure 2. Interaction between TLOC and ensiling time for kernel particles retained in the

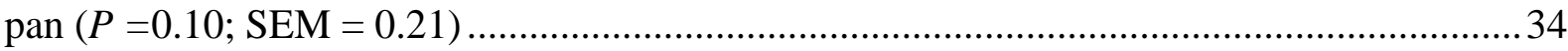

Figure 3. Plasma glucose concentration at $6 \mathrm{~h}(\square)$ or $12 \mathrm{~h}$ post-feeding ( $\square$ ) for treatments PT6, SP6, SP12 or SP18 $(P$ PT6 vs. SP6 $=0.03 ; P$ SP6 vs. SP12 $=0.80 ; P$ SP12 vs. SP18 $=$ $0.08 ; P$ treat $=0.05 ; P$ time $=0.18 ; P$ treat $*$ time $=0.83 ; \mathrm{SEM}=2.61)$ .660

Figure 4. Plasma urea nitrogen (PUN) at $0,1,2,3,6,12$ and $15 \mathrm{~h}$ post-feeding on treatments PT6, SP6, SP12 or SP18 (P PT6 vs. SP6 = 0.36; P SP6 vs. SP12 = 0.19; P SP12 vs. $\mathrm{SP} 18=0.51 ; \mathrm{P}$ treat $=0.60 ; \mathrm{P}$ time $<0.01 ; \mathrm{P}$ treat $*$ time $=0.57 ; \mathrm{SEM}=1.77)$ 66 


\section{LIST OF TABLES}

Table 1. Effect of theoretical length of cut on particle size distribution and mean particle length in whole-corn silage harvested with a pull-type forage harvester .............................. 27

Table 2. Effect of ensiling time on particle size distribution and mean particle length in whole-corn silage harvested with a pull-type forage harvester.............................................. 28

Table 3. Effect of theoretical length of cut on kernel fraction particle size distribution, geometric mean particle size (GMPS), surface area and processing score in whole-corn silage harvested with a pull-type forage harvester 28

Table 4. Effect of ensiling time on kernel fraction particle size distribution, geometric mean particle size (GMPS), surface area and processing score in whole-corn silage harvested with a pull-type forage harvester

Table 5. Effect of theoretical length of cut on particle size distribution and mean particle length in whole-corn silage harvested with a self-propelled forage harvester. 30

Table 6. Effect of ensiling time on particle size distribution and mean particle length in whole-corn silage harvested with a self-propelled forage harvester. 31

Table 7. Effect of theoretical length of cut on kernel fraction particle size distribution, geometric mean particle size (GMPS), surface area and processing score in whole-corn silage harvested with a self-propelled forage harvester 32

Table 8. Effect of ensiling time on kernel fraction particle size distribution, geometric mean particle size (GMPS), surface area, and processing score in whole-corn silage harvested with a self-propelled forage harvester.. 33

Table 9. Penn state particle size distribution and mean particle length .............................. 45

Table 10. starch content by each Penn State Particle Size Separator sieve ......................... 45

Table 11. Kernel fraction particle size distribution, proportion of kernels smaller than 4.75$\mathrm{mm}$, geometric mean particle size (GMPS), and surface area of treatments ........................ 46

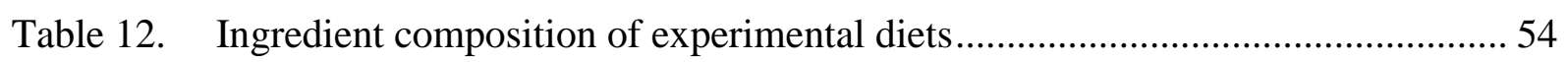

Table 13. Nutrient composition and particle size of experimental diets (mean \pm SD)......... 56

Table 14. Chemical composition, fermentation, and physical characteristics of whole-plant

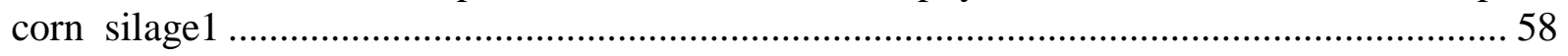

Table 15. Effect of corn silage processing on the performance of dairy cows 1 .................. 63

Table 16. Effect of corn silage processing on nutrient intake and apparent digestibility1 .. 64

Table 17. Effect of corn silage processing on urinary purine derivatives 1 .......................... 64

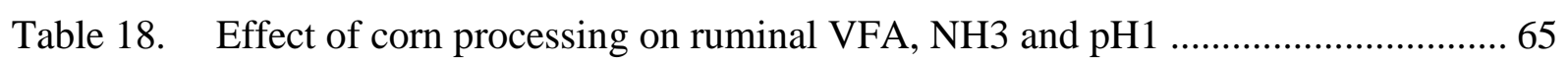

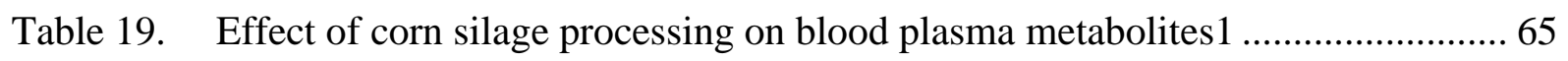

Table 20. Influence of corn silage processing on feeding behavior of dairy cows 1 ............ 68

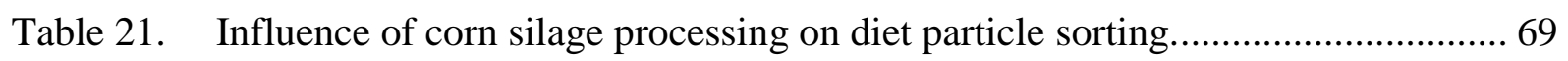

Table 22. Influence of corn silage processing on milk fatty acid profile1 $(\mathrm{g} / 100 \mathrm{~g}) \ldots \ldots \ldots . . . .70$ 
Table 23. Milk fatty acids as daily secretion (Assumes milk fat is $93.3 \%$ fatty acids and $6.7 \%$ glycerol $)(\mathrm{g} / \mathrm{d})$ 


\section{INTRODUCTION}

Whole-plant corn silage (WPCS) is a major source of forage for lactating dairy cattle in Brazil (Bernardes and Rêgo, 2014), in the United States (Martin et al., 2017, Ferraretto et al., 2018), and world-wide (Ferraretto et al., 2018). The high adoption of WPCS is due to the provision of high energy (mainly from starch in the kernel fraction) and physically effective NDF (peNDF; derived from the stover fraction, Ferraretto et al., 2018). Furthermore, WPCS has high yield of low-cost starch per hectare (Wilkinson and Rinne, 2018), minimized risks of production, flexibility to harvest corn for forage or kernel (Allen et al., 2003), rapid harvest, and ease of ensiling (Nigon et al., 2016).

Approximately $72 \%$ of the kernel fraction is composed by starch (DM basis; Huntington, 1997) that represents nearly $45 \%$ of the whole-plant DM (Philippeau and Michalet-Doreau, 1998) and about half of the energy in WPCS (calculated using NRC, 2001). The total-tract starch digestibility (TTSD, from 80 to 98\%) of WPCS has high variability in lactating dairy cows fed WPCS-based diets (Ferraretto and Shaver, 2012). Kernel processing WPCS through rollers during harvest fractures corn kernels (Johnson et al., 1999; Shinners et al., 2000) and increases TTSD (Bal et al., 2000). Nonetheless, its efficiency is influenced by maturity, theoretical length of cut (TLOC), type of processor, roll speed differential and processor roll-gap clearance (Shinners et al., 2000; Ferraretto and Shaver, 2012a,b). Kernel vitreousness increases along with the maturity of WPCS (Philippeau and Michalet-Doreau, 1997), and with a high WPCS dry matter content (>40\%) the TTSD was not improved by kernel processing to the same extent as less mature WPCS (Ferraretto and Shaver, 2012). This situation may occur in Brazilian vitreous corn hybrids even with a DM below $40 \%$.

Extended ensiling time leads to a proteolysis of zein proteins and a disassociation of starch-protein clusters in high-moisture corn which could allow for a greater surface area for rumen bacteria (Hoffman et al., 2011). Higher values of proteolysis markers (soluble CP and ammonia-N) followed by an improvement in ivSD have been observed in WPCS stored for long periods of time (Ferraretto et al., 2015a). Ferraretto et al. (2015b) reported a rise of 7 to $10 \%$ units for corn silage processing score (CSPS) in WPCS ensiled for at least $30 \mathrm{~d}$ and up to $240 \mathrm{~d}$.

Different corn silage processing has been implemented on some of the self-propelled forage harvesters (SPFH) being used on farms. Changes include shredlage processors, shredder rolls, conventional processors with greater roll speed differentials (Ferraretto et al., 2018), and inter-meshing disc processors (Salvati et al., 2015). There has been interest in 
setting the forage harvester for a longer theoretical length of cut (TLOC) with the aim of increasing the mean particle length (MPL) of WPCS. To harvest WPCS, greater TLOC settings $(\geq 19-\mathrm{mm})$ are used on customized forage harvesters that are equipped with kernelprocessing rolls in an attempt to maintain or improve fiber effectiveness as the stover is also crushed by the rolls (Johnson et al., 2003). Increasing the TLOC of forages might be a strategy to increase the peNDF of diets (Mertens, 1997) which may improve rumination activity, salivary buffering and rumen mat formation in dairy cows (Mertens, 1997; Zebeli et al., 2012). However, the concerns of this practice is feed bunk sorting in high TLOC forages (Vanderwerrff et al., 2015) that can make dairy cows prone to subacute ruminal acidosis (SARA). We still are lacking scientific evidence to support this decision.

Despite the increase in custom contractors offering self-propelled forage harvester (SPFH) services (Daniel et al., 2019), the most part of Brazilian dairy farmers harvest the corn crop with a pull-type forage harvester (PTFH) without a kernel processor (KP; Bernardes and Rego, 2014). In addition, the most cultivated hybrids have flint kernel with a higher proportion of vitreous endosperm (Correa et al., 2002; Bernardes et al., 2018) which is more difficult to damage during harvesting (Ferraretto et al. 2018); thereby compromising kernel processing. In the United States, the typical range of TLOC to chop corn plants by SPFH is from 19-mm to 26-mm (Grant and Ferraretto, 2018) and between 10 to 13-mm for PTFH without kernel processor (Kung and Muck, 2017). However, the hypothesis of our study was that to achieve adequate kernel processing in WPCS from vitreous endosperm hybrid a lower TLOC and high ensiling time would be required for the both types of forage harvesters (SPFH and PTFH).

\section{References}

Allen, M. S., J. G. Coors, and G. W. Roth. 2003. Corn silage. Pages 547-608 in Silage Science and Technology. D. R. Buxton, R. E. Muck, and H. J. Harrison, ed. ASA, CSA, and SSSA, Madison, WI.

Bal, M. A., R. D. Shaver, A. G. Jirovec, K. J. Shinners, and J. G. Coors. 2000. Crop processing and chop length of corn silage: Effects on intake, digestion, and milk production by dairy cows. J. Dairy Sci. 83:1264-1273.

Bernardes, T. F., and A. C. Rego. 2014. Study on the practices of silage production and utilization on Brazilian dairy farms. J. Dairy Sci. 97:1852-1861. 
Bernardes, T. F., J. L. P. Daniel, A. T. Adesogan, T. A. McAllister, P. Drouin, L. G. Nussio, P. Huhtanen, G. F. Tremblay, G. Bélanger, and Y. Cai. 2018. Silage review: Unique challenges of silages made in hot and cold regions. J. Dairy Sci. 101:4001-4019.

Correa, C. E. S., R. D. Shaver, M. N. Pereira, J. G. Lauer, and K. Kohn. 2002. Relationship between corn vitreousness and ruminal in situ starch degradability. J. Dairy Sci. 85:30083012.

Daniel, J. L. P., Bernardes, T. F., C. C. Jobim, P. Schmidt, and L. G. Nussio.Production and utilization of silages in tropical areas with focus in Brazil. 2019. Grass Forage Sci. 1-13.

Dias Junior, G. S., L. F. Ferraretto, G. G. S. Salvati, L. C. de Resende, P. C. Hoffman, M. N. Pereira, and R. D. Shaver. 2016. Relationship between processing score and kernelfraction particle size in whole-plant corn silage. J. Dairy Sci. 99:2719-2729.

Der Bedrosian, M. C., L. Kung Jr., and K. E. Nestor Jr.. 2012. The effects of hybrid, maturity and length of storage on the composition and nutritive value of corn silage. J. Dairy Sci. 95:5115-5126.

Grant, R. J, and L. F. Ferraretto. Silage review: Silage feeding management: Silage characteristics and dairy cow feeding behavior. J. Dairy Sci. 101:4111-4121.

Ferraretto, L. F., and R. D. Shaver. 2012a. Effect of corn shredlage on lactation performance and total tract starch digestibility by dairy cows. Prof. Anim. Sci. 28:639-647.

Ferraretto, L. F., and R. D. Shaver. 2012b. Meta-analysis: Impact of corn silage harvest practice on intake, digestion and milk production by dairy cows. Prof. Anim. Sci. 28:141149.

Ferraretto, L. F., P. M. Crump, and R. D. Shaver. 2015a. Effect of ensiling time and exogenous protease addition to whole-plant corn silage of various hybrids, maturities and chop lengths on nitrogen fractions and ruminal in vitro starch digestibility. J. Dairy Sci. 98:8869-8881.

Ferraretto, L. F., G. S. Dias Junior, L. C. de Resende, and R. D. Shaver. 2015b. Effect of ensiling on kernel processing score in whole-plant corn silage harvested with varied processors and settings. J. Dairy Sci. 98(Suppl. 2):689. (Abstr.)

Ferraretto, L. F., R. D. Shaver, and B. D. Luck. 2018. Silage review: Recent advances and future technologies for whole-plant and fractionated corn silage harvesting. J. Dairy Sci. 101:3937-3951.

Hoffman, P. C., N. M. Esser, R. D. Shaver, W. Coblentz, M. P. Scott, A. L. Bodnar, R. Schmidt, and B. Charely. 2011. Influence of inoculation and storage time on alteration of the starch-protein matrix in high moisture corn. J. Dairy Sci. 94:2465-2474. 
Huntington, G. B. 1997. Starch utilization by ruminants: From basics to the bunk. J. Anim. Sci. 75:852-867.

Johnson, L., J. H. Harrison, C. Hunt, K. Shinners, C. G. Doggett, and D. Sapienza. 1999. Nutritive value of corn silage as affected by maturity and mechanical processing: A contemporary review. J. Dairy Sci. 82:2813-2825.

Johnson, L. M., J. H. Harrison, D. Davidson, W. C. Mahanna, and K. Shinners. 2003. Corn silage management: Effects of hybrid, chop length, and mechanical processing on digestion and energy content. J. Dairy Sci. 86:208-231.

Kung Jr., L., and R. E. Muck. Silage harvesting and storage. 2017. Pages 723-738 in Large Dairy Herd Management ( $3^{\circ}$ ed.) edited by D. K. Beede. 1376 p.

Martin, N. P., M. P. Russelle, J. M. Powell, C. J. Sniffen, S. I. Smith, J. M. Tricarico, and R. J. Grant. 2017. Invited review: Sustainable forage and kernel crop production for the US dairy industry. J. Dairy Sci. 100:9479-9494.

Mertens, D. R. 1997. Creating a system for meeting the fiber requirements of dairy cows. J. Dairy Sci. 80:1463-1481.

Nigon, B. J., K. J. Shinners, and D. E. Cook. 2016. Harvester modifications to alter composition and dry matter of corn-silage. Appl. Eng. Agric. 32:157-167.

National Research Council. 2001. Nutrient requirements of dairy cattle. 7th rev. ed. Natl. Acad. Sci., Washington D.C.

Philippeau, C., and B. Michalet-Doreau. 1997. Influence of genotype and stage of maturity of maize on rate of ruminal starch degradation. Anim. Feed Sci. Technol. 68:25-35.

Philippeau, C., and B. Michalet-Doreau. 1998. Influence of genotype and ensiling of corn kernel on in situ degradation of starch in the rumen. J. Dairy Sci. 81:2178-2184.

Salvati, G. S. S., R. D. Shaver, M. Lippert, E. Ronk, and C. Wacek-Driver. 2015. Corn Silage Processing: Dairy Farm Survey. Accessed Feb. 16, 2019. https:// shaverlab dysci .wisc .edu/wp -content/ uploads/sites/ 87/ 2015/ 04/ cornsilageprocessingsurveysummaryreport .pdf.

Shinners, K. J., A. G. Jirovec, R. D. Shaver, and M. Bal. 2000. Processing whole-plant corn silage with crop processing rolls on a pull-type forage harvester. Appl. Eng. Agric. 16:323-331.

Shinners, K. J. 2003. Engineering principles of silage harvesting equipment. Pages 361-403 in Silage Science and Technology. D. R. Buxton, R. E. Muck, and H. J. Harrison, ed. ASA, CSA, and SSSA, Madison, WI. 
Vanderwerff, L. M., L. F. Ferraretto, and R. D. Shaver. 2015. Brown midrib corn shredlage in diets for high-producing dairy cows. J. Dairy Sci. 98:5642-5652.

Wilkinson, J. M., and Rinne, M. 2017. Review: Highlights of progress in silage conservation and future perspectives. Grass and Forage Science 73:40-52.

Zebeli, Q., J. R. Aschenbach, M.Tafaj, J. Boguhn, B. N. Ametaj, and W. Drochner. 2012. Invited review: role of physically effective fiber and estimation of dietary fiber adequacy in high-producing dairy cattle. J. Dairy Sci. 95:1041-1056. 


\title{
2. STRATEGIES TO MAXIMIZE KERNEL PROCESSING IN BRAZILIAN VITREOUS ENDOSPERM HYBRID
}

\begin{abstract}
Whole-plant corn silage (WPCS) is a major source of forage for lactating dairy cattle in Brazil. Improved kernel processing may be especially advantageous when feeding corn hybrids with vitreous endosperm, which are more difficult to be broken. Two experiments were conducted to evaluate the effects of theoretical length of cut (TLOC) and ensiling time on whole-plant corn silage (WPCS) particle size and kernel processing with two types of forage harvesters. The same vitreous corn hybrid DKB 177 VT PRO 2 was used in both experiments. In the first experiment, the whole-plant corn was harvested by a pull-type forage harvester (PTFH) at TLOC of 3,6 and 9-mm. In the second experiment, the harvesting was performed by a self-propelled forage harvester (SPFH) at the following TLOC settings: 6,12 and $18-\mathrm{mm}$ with a roll gap of 3-mm. The WPCS were stored for 0,35 and $140 \mathrm{~d}$. Vitreousness, measured by dissection in unfermented kernels, averaged $65.6 \%$. Data from both trials were analyzed as a split-plot design using the procedure MIXED of SAS (SAS Institute Inc., Cary, NC). The model included the fixed effects of TLOC, ensiling time and the interaction TLOC $\times$ ensiling time. In PTFH, the TLOC of 3 and 6-mm did not differ WPCS particle size distribution and mean particle length (MPL). However, the TLOC of 9-mm increased particles above the top 2 sieves and, as a consequence, the MPL. The rise of TLOC in SPFH led to a higher MPL and percentage of long particles (> 19-mm). The ensiling time increased MPL and long particles only for WPCS harvested by SPFH. The strategy of reducing TLOC in SPFH increased the percentage of kernels smaller than 4.75-mm. Furthermore, The TLOC of 6-mm led to the best kernel processing for SPFH. The ensiling time reduced the particle size of kernel fraction for both forage harvesters. The corn silage processing score only improved with $140 \mathrm{~d}$ of ensiling for SPFH samples. These findings suggest that ensiling time and low TLOC in SPFH (6-mm) may be good strategies to increase kernel damage and thus starch digestibility in WPCS.
\end{abstract}

Keywords: Kernel particle size; Vitreous endosperm; Ensiling time; Theoretical length of cut

\subsection{INTRODUCTION}

Whole-plant corn silage (WPCS) is the predominat source of forage for lactating dairy cattle in Brazil (Bernardes and Rêgo, 2014) and worldwide (Ferraretto et al., 2018). It is a high-energy forage composed by stover and kernel fractions which are rich in NDF and starch contents, respectively (Dias Junior et al., 2016). For the greatest availability of starch in WPCS the kernel processing is crucial (Ferraretto and Shaver, 2012). Despite the increase in 
custom contractors offering self-propelled forage harvester (SPFH) services (Daniel et al., 2019), the most part of Brazilian dairy farmers harvest the corn crop with a pull-type forage harvester (PTFH) without a kernel processor (KP; Bernardes and Rego, 2014). This is a concern because the most cultivated hybrids in Brazil have vitreous kernels with higher vitreous endosperm proportion (Correa et al., 2002; Bernardes et al., 2018). Futhermore, higher vitreous endosperm is related to kernel hardness (Correa et al., 2002) which makes kernels more difficult to be broken by the harvester's processors (Ferraretto et al. 2018) and this could be worse for a PTFH without KP.

Kernel processing WPCS by rollers during harvest fractures corn kernels (Johnson et al., 1999, Shinners et al., 2000) and increases total-tract starch digestibility (TTSD; Bal et al., 2000). Nonetheless, its efficiency is influenced by maturity, theoretical length of cut (TLOC), type of processor, roll speed differential and processor roll-gap clearance (Shinners et al., 2000; Ferraretto and Shaver, 2012a,b). Kernel vitreousness increases throughout the maturity of WPCS (Johnson et al., 1999) and with a high WPCS dry matter content (>40\%) the TTSD is reduced (Ferraretto and Shaver, 2012). This situation can occur in Brazilian vitreous corn hybrids even with a DM below $40 \%$.

The in vitro starch digestibility (ivSD) of WPCS is improved by a longer length of storage (Der Bedrosian et al., 2012). Extended time stored in silos leads to a proteolysis of zein proteins and a disassociation of starch-protein clusters in high moisture corn which could allow for a greater surface area for rumen bacteria (Hoffman et al., 2011). Higher values of proteolysis markers (soluble $\mathrm{CP}$ and ammonia-N) followed by an improvement in ivSD have been observed in WPCS stored for long periods of time (Ferraretto et al., 2015a). Ferraretto et al. (2015b) reported a rise of 7 to $10 \%$-units for corn silage processing score (CSPS) in WPCS ensiled for at least $30 \mathrm{~d}$ and up to $240 \mathrm{~d}$. Based on this, it is possible to presume that a increased length could reduce kernel particle size.

In general, dairy farmers increase TLOC with the aim of increasing particle size of WPCS and thereby achieving a greater physically effective fiber (peNDF; Mertens, 1997; Ferraretto et al., 2018). For WPCS the TLOC is usually between 10 to $13-\mathrm{mm}$ for unprocessed and about 19-mm for processed (Shinners et al., 2003; Kung and Muck, 2017). Ferraretto and Shaver et al. (2012) reported no impact of kernel processing in ruminal starch digestibility when WPCS was harvested with a high TLOC (> 32-mm). The hypothesis of our study was that in order to achieve adequate kernel processing in vitreous endosperm hybrid, a lower TLOC and a longer length of storage would be required. The objective of this study was 
to evaluate the impact of two different types of forage harvesters, TLOC settings and ensiling time on the physical characteristics WPCS.

\subsection{MATERIALS AND METHODS}

\subsubsection{Silage production and treatments}

Three hectares of a vitreous corn silage hybrid (DKB 177 VT PRO 2, Dekalb, Monsanto, Dekalb, Illinois, USA) were sown on November 4, 2015, at a density of 68,750 seeds per hectare at the Luiz de Queiroz College of Agriculture - University of São Paulo (Piracicaba, São Paulo, Brazil). The harvesting occurred on February 17, 2016, at approximately $34.0 \%$ DM of the whole-plant corn. The field was harvested in alternating strips in an attempt to keep similar nutrient composition among the treatments. The treatments were performed during the harvest. Corn vitreousness was determined by manual dissection of the kernels (Dombrink-Kurtzman and Bietz, 1993) in fifteen ears collected from the corn crop according to the procedure described by Correa et al. (2002).

In the first experiment, a PTFH without KP (JF AT 1600; JF Máquinas Agrícolas, Itapira, Brazil) set for a TLOC of 3, 6 and 9-mm was used in impose harvesting treatments. The samples of $8.5 \mathrm{~kg}$ were ensiled in 10-L bucket (density of $850 \mathrm{~kg} \cdot \mathrm{m}^{-3}$ ) and stored for 0 , 35 and $140 \mathrm{~d}$. This experiment consisted of 9 treatments (3 lengths of cut and 3 lengths of storage) and 36 mini-silos (4 replications per treatment). In the second experiment, a SPFH (FR 9050; CNH Industrial, New Holland, Pennsylvania, USA) equipped with conventional rolls set at a $3-\mathrm{mm}$ roll-gap and $20 \%$ roll speed differential was used to harvest the following TLOC treatments: 6, 12, and 18-mm. All samples were ensiled as described in the first experiment. Again, this experiment also consisted of 9 treatments (3 lengths of cut and 3 lengths of storage) and 36 mini-silos (4 replications per treatment). The mini-silos were stored at natural environment conditions until achieving the targeted of length of storage. After the storage period reached 35 and $140 \mathrm{~d}$, the mini-silos were opened and the samples were manipulated immediately.

\subsubsection{Physical and chemical characteristics}

The samples of WPCS were homogenized manually and divided into 4 equal subsamples of $500 \mathrm{~g}$ using a quartering technique. The first subsample, as-fed WPCS samples 
were used for the determination of particle size distribution and MPL using a Penn State Particle Size Separator (PSPS). The PSPS procedure was conducted manually using 3 sieves (19, 8 and 1.18-mm) and a bottom pan according to the method of Kononoff et al. (2003).

The second subsample was dried at $60^{\circ} \mathrm{C}$ for $48 \mathrm{~h}$ in a forced-air oven and then ground to pass through a 1-mm Wiley mill screen (Arthur H. Thomas). The DM (method 942.05) and ether extract (method 2003.05) were determined as described by AOAC International (2012). Concentration of CP was determined as $\mathrm{N}$ x 6.25 after analysis with a $\mathrm{N}$ analyzer (Leco FP-2000; Leco Corp., St. Joseph, MI, USA) by the Dumas method (Wiles et al., 1998). The NDF was analyzed using a TE-149 fiber analyzer (TECNAL Equipamentos para Laboratórios, Piracicaba, Brazil) with heat-stable $\alpha$-amylase and sodium sulfite (method 2002.04, AOAC, 2012). Starch was analyzed according to Hall et al. (2015). This data was used only for the description of WPCS nutritional composition.

The third subsample was not ground. It was dried at $60^{\circ} \mathrm{C}$ for $48 \mathrm{~h}$ in a forced-air oven to evaluate corn silage processing score (CSPS) as described by Ferreira and Mertens (2005). In the fourth subsample, kernel and stover fractions were separated by a hydrodynamic separation procedure (Savoie et al., 2004). This method is based on differences in buoyancy between the kernels and stover. Because all samples were fermented for at least $35 \mathrm{~d}$, which is thought to make the separation process more difficult, all samples were dried in a forced-air oven set at $60^{\circ} \mathrm{C}$ for $48 \mathrm{~h}$ prior to immersion in water as recommended by Savoie et al. (2004). Each sample of approximately $400 \mathrm{~g}$ of DM was placed in a 10-L rectangular tub containing $7 \mathrm{~L}$ of water. Each dried sample was gently agitated manually for 2 min such that the entire sample was submerged in water. After $2 \mathrm{~min}$, the stover fraction which floated, due to a lower density than water, was removed gently using a small 1.18-mm sieve (Savoie et al., 2004). After separation, the kernel-fraction was transferred to aluminum plates, re-dried at $60^{\circ} \mathrm{C}$ for $48 \mathrm{~h}$ in a forced-air oven and dry-sieved using a Tyler Ro-Tap Shaker (model RX29, Tyler, Mentor, $\mathrm{OH}$ ) with a set of 9 sieves with nominal square apertures of 9.50, 6.70, $4.75,3.35,2.36,1.70,1.18,0.59-\mathrm{mm}$ and bottom pan. The geometrical mean particle size (GMPS; $\mu \mathrm{m})$ and surface area $\left(\mathrm{cm}^{2} \cdot \mathrm{g}^{-1}\right)$ were calculated using a log normal distribution (Baker and Herrman, 2002) as described by Dias Junior et al. (2016). The proportion of kernels smaller than $4.75-\mathrm{mm}$ was calculated by the sum of percentages retained at 3.35, 2.36, 1.70, 1.18 and 0.59-mm sieves and bottom pan (Dias Junior et al., 2016). 


\subsubsection{Statistical analysis}

Data from both trials was analyzed as a split-plot design using the procedure MIXED of SAS (SAS Institute Inc., Cary, NC). The model included the fixed effects of TLOC, ensiling time and the interaction TLOC $\times$ ensiling time. A mini-silo was used as the experimental unit. Means were determined using the LSMEANS statement and were compared using the Tukey test at $5 \%$ of significance. Statistical significance and trends were considered at $\mathrm{P} \leq 0.05$ and $\mathrm{P}>0.06$ to $\mathrm{P} \leq 0.10$, respectively.

\subsection{RESULTS}

The kernel vitreousness of the hybrid was $65.6 \pm 3.7 \%$ of total endosperm (data not shown in tables or figures). The chemical composition of whole-plant corn was (\% of DM) $6.4 \pm 1.4$ for $\mathrm{CP}, 3.4 \pm 1.4$ for EE, $43.6 \pm 0.8$ for NDF and $30.6 \pm 1.7$ for starch. The average of DM among treatments ( $\%$ of as fed) was $35.2 \%$.

\subsubsection{Experiment 1}

Reducing TLOC from 6 to 3-mm did not impact particle size distribution and MPL on PTFH samples (Table 1). However, the highest TLOC (9-mm) increased the percentage of particles retained at the top 2 PSPS sieves which, as consequence, led to the decreased retention of material at $1.18-\mathrm{mm}$ sieve and bottom pan. A greater MPL (11.5-mm) was observed for this TLOC.

Table 1. Effect of theoretical length of cut on particle size distribution and mean particle length in WPCS silage harvested with a pull-type forage harvester

\begin{tabular}{|c|c|c|c|c|c|}
\hline \multirow[b]{2}{*}{ Item } & \multicolumn{3}{|c|}{ TLOC } & \multirow[b]{2}{*}{ SEM } & \multirow[b]{2}{*}{$P$-value } \\
\hline & 3 & 6 & 9 & & \\
\hline \multicolumn{6}{|l|}{ Sieve $^{1}$} \\
\hline 19-mm & $9.8^{\mathrm{b}}$ & $8.2^{\mathrm{b}}$ & $13.7^{\mathrm{a}}$ & 0.83 & $<0.01$ \\
\hline 8-mm & $69.3^{b}$ & $68.9^{b}$ & $72.4^{\mathrm{a}}$ & 0.66 & 0.03 \\
\hline $1.18-\mathrm{mm}$ & $18.9^{\mathrm{a}}$ & $20.8^{\mathrm{a}}$ & $12.6^{\mathrm{b}}$ & 0.61 & $<0.01$ \\
\hline Bottom pan & $1.9^{\mathrm{a}}$ & $1.9^{\mathrm{a}}$ & $1.4^{\mathrm{b}}$ & 0.10 & 0.01 \\
\hline $\mathrm{MPL}^{2}, \mathrm{~mm}$ & $10.2^{\mathrm{b}}$ & $9.8^{\mathrm{b}}$ & $11.5^{\mathrm{a}}$ & 0.15 & 0.01 \\
\hline Sgm & $1.96^{\mathrm{a}}$ & $1.95^{\mathrm{a}}$ & $1.86^{\mathrm{b}}$ & 0.153 & $<0.01$ \\
\hline
\end{tabular}

${ }^{\mathrm{a}-\mathrm{c}}$ Means in the same row with different superscripts differ by Tukey test $(P \leq 0.05)$.

${ }^{1}$ Percentage of particles retained on each sieve (as fed basis) of Penn State Particle Size Separator.

${ }^{2}$ Mean particle length calculated as described by Kononoff et al. (2003). 
The ensiling time did not change particle size distribution and MPL (Table 2). There was no interaction between TLOC and ensiling time for particle size distribution results (P > $0.20)$.

Table 2. Effect of ensiling time on particle size distribution and mean particle length in WPCS harvested with a pull-type forage harvester

\begin{tabular}{|c|c|c|c|c|c|}
\hline \multirow[b]{2}{*}{ Item } & \multicolumn{3}{|c|}{ Ensiling time } & \multirow[b]{2}{*}{ SEM } & \multirow[b]{2}{*}{$P$-value } \\
\hline & 0 & 35 & 140 & & \\
\hline \multicolumn{6}{|l|}{ Sieve $^{1}$} \\
\hline 19-mm & 10.8 & 9.6 & 11.3 & 0.78 & 0.32 \\
\hline 8-mm & 70.1 & 71.0 & 69.7 & 0.75 & 0.46 \\
\hline $1.18-\mathrm{mm}$ & 17.2 & 17.9 & 17.2 & 0.61 & 0.62 \\
\hline Bottom pan & 1.8 & 1.6 & 1.8 & 0.10 & 0.12 \\
\hline MPL, mm & 10.5 & 10.4 & 10.6 & 0.15 & 0.72 \\
\hline Sgm & 1.93 & 1.90 & 1.95 & 0.15 & 0.12 \\
\hline
\end{tabular}

${ }^{1}$ Percentage of particles retained on each sieve (as fed basis) of Penn State Particle Size Separator.

${ }^{2}$ Mean particle length calculated as described by Kononoff et al. (2003).

Table 3. Effect of theoretical length of cut on kernel fraction particle size distribution, geometric mean particle size (GMPS), surface area and processing score in WPCS harvested with a pull-type forage harvester

\begin{tabular}{|c|c|c|c|c|c|}
\hline \multirow[b]{2}{*}{ Item } & \multicolumn{3}{|c|}{ TLOC } & \multirow[b]{2}{*}{ SEM } & \multirow[b]{2}{*}{$P$-value } \\
\hline & 3 & 6 & 9 & & \\
\hline \multicolumn{6}{|l|}{ Sieve $^{1}, \mathrm{~mm}$} \\
\hline 6.7 & 36.3 & 35.9 & 36.9 & 0.97 & 0.79 \\
\hline 4.75 & 38.4 & 39.3 & 38.8 & 0.81 & 0.79 \\
\hline 3.35 & 8.8 & 8.8 & 8.9 & 0.28 & 0.95 \\
\hline 2.36 & 6.3 & 6.3 & 6.2 & 0.36 & 0.98 \\
\hline 1.70 & 3.2 & 3.1 & 2.9 & 0.16 & 0.58 \\
\hline 1.18 & 2.3 & 2.1 & 2.1 & 0.12 & 0.30 \\
\hline 0.59 & 2.6 & 2.5 & 2.4 & 0.14 & 0.57 \\
\hline Pan & 2.1 & 2.1 & 1.9 & 0.13 & 0.51 \\
\hline$\%<4.75^{2}$ & 25.3 & 24.8 & 24.3 & 0.93 & 0.79 \\
\hline GMPS, $\mu \mathrm{m}$ & 5070.0 & 5090.4 & 5172.8 & 62.5 & 0.48 \\
\hline Surface area, $\mathrm{cm}^{2} / \mathrm{g}$ & 11.1 & 11.0 & 10.6 & 0.25 & 0.31 \\
\hline Processing score $^{3}$ & 24.7 & 26.4 & 25.0 & 1.71 & 0.76 \\
\hline
\end{tabular}

${ }^{1}$ Percentage of particles retained on each sieve (DM basis).

${ }^{2}$ Proportion of kernel fraction passing through a $4.75-\mathrm{mm}$ sieve.

${ }^{3}$ Percent of starch passing a $4.75-\mathrm{mm}$ sieve; processing score was measured as described by Ferreira and Mertens (2005).

The different TLOC did not change kernel fraction particle size distribution (Table 3). As a result the GMPS, surface area and proportion of kernel fraction passing through a 4.75mm sieve were not affected among treatments. The CSPS values were too low and varied 
from 24.7 to $26.4 \%$. Despite no effect for TLOC, the ensiling time changed the kernel particle size distribution regardless the extension of ensiling time, either 35 or $140 \mathrm{~d}$ (Table 4). The percentage of particles retained at $6.7-\mathrm{mm}$ sieve was decreased by 13.2 and $11.3 \%$ units, respectively for 35 and $140 \mathrm{~d}$ of storage in comparison with unfermented samples. There was a rise of particles retained at 4.75, 1.18 and $0.59-\mathrm{mm}$ sieves and pan. A higher surface area and proportion of kernels smaller than $4.75-\mathrm{mm}$ was observed for both lengths of storage in comparison with unfermented. A reduction in GMPS occurred, however, the CSPS was not impacted. No interaction was observed between TLOC and ensiling time for kernel fraction variables and CSPS $(\mathrm{P}>0.11)$.

Table 4. Effect of ensiling time on kernel fraction particle size distribution, geometric mean particle size (GMPS), surface area and processing score in WPCS harvested with a pull-type forage harvester

\begin{tabular}{|c|c|c|c|c|c|}
\hline \multirow[b]{2}{*}{ Item } & \multicolumn{3}{|c|}{ Ensiling time } & \multirow[b]{2}{*}{ SEM } & \multirow[b]{2}{*}{$P$-value } \\
\hline & 0 & 35 & 140 & & \\
\hline \multicolumn{6}{|l|}{ Sieve $^{1}, \mathrm{~mm}$} \\
\hline 6.7 & $44.5^{\mathrm{a}}$ & $31.3^{\mathrm{b}}$ & $33.2^{\mathrm{b}}$ & 0.97 & $<0.01$ \\
\hline 4.75 & $32.9^{\mathrm{b}}$ & $42.9^{\mathrm{a}}$ & $40.7^{\mathrm{a}}$ & 0.81 & $<0.01$ \\
\hline 3.35 & 8.2 & 9.1 & 9.2 & 0.28 & 0.05 \\
\hline 2.36 & 6.2 & 6.2 & 6.5 & 0.36 & 0.71 \\
\hline 1.70 & 3.2 & 3.1 & 2.9 & 0.16 & 0.01 \\
\hline 1.18 & $1.8^{\mathrm{b}}$ & $2.3^{\mathrm{a}}$ & $2.4^{\mathrm{a}}$ & 0.12 & $<0.01$ \\
\hline 0.59 & $2.1^{\mathrm{b}}$ & $2.7^{\mathrm{a}}$ & $2.7^{\mathrm{a}}$ & 0.14 & 0.02 \\
\hline Pan & $1.6^{\mathrm{b}}$ & $2.4^{\mathrm{a}}$ & $2.3^{\mathrm{a}}$ & 0.13 & $<0.01$ \\
\hline$\%<4.75^{2}$ & $22.3^{b}$ & $25.8^{\mathrm{a}}$ & $26.5^{\mathrm{a}}$ & 0.84 & 0.03 \\
\hline GMPS, $\mu \mathrm{m}$ & $5419.1^{\mathrm{a}}$ & $4930.2^{b}$ & $4980.3^{b}$ & 62.5 & $<0.01$ \\
\hline Surface area, $\mathrm{cm}^{2} / \mathrm{g}$ & $9.8^{\mathrm{b}}$ & $11.4^{\mathrm{a}}$ & $11.4^{\mathrm{a}}$ & 0.25 & $<0.01$ \\
\hline Processing score ${ }^{3}$ & 26.1 & 23.4 & 26.6 & 1.65 & 0.37 \\
\hline
\end{tabular}

${ }^{a-b}$ Means in the same row with different superscripts differ by Tukey test $(P \leq 0.05)$.

${ }^{1}$ Percentage of particles retained on each sieve (DM basis).

${ }^{2}$ Proportion of kernel fraction passing through a $4.75-\mathrm{mm}$ sieve.

${ }^{3}$ Percent of starch passing a $4.75-\mathrm{mm}$ sieve; processing score was measured as described by Ferreira and Mertens (2005).

\subsubsection{Experiment 2}

The WPCS particle size distribution was affected by the different TLOC settings on SPFH samples (Table 5). The percentage of material retained at the top PSPS sieve was different among treatments $(4.5,8.0$ and $15.6 \%$, respectively for the following TLOC settings of 6,12 and $18-\mathrm{mm})$. In the $8-\mathrm{mm}$ sieve, the highest value $(66.2 \%$ particles retained) was 
observed for TLOC of 12-mm. For the TLOC settings of 6 and 18-mm the amounts retained in the same sieve size were, respectively, 56.2 and $63.1 \%$. The decrease of TLOC from 18 to 6-mm led to a rise in percentage of material retained in the $1.18-\mathrm{mm}$ sieve from 17.7 to $34.2 \%$. The TLOC of 12 and 18-mm had minor amounts of particles in the PSPS pan in comparison with the lowest TLOC (6- mm). A rise in MPL occurred accordingly with increments of TLOC.

Table 5. Effect of theoretical length of cut on particle size distribution and mean particle length in WPCS harvested with a self-propelled forage harvester

\begin{tabular}{|c|c|c|c|c|c|}
\hline \multirow[b]{2}{*}{ Item } & \multicolumn{3}{|c|}{ TLOC } & \multirow[b]{2}{*}{ SEM } & \multirow[b]{2}{*}{$P$-value } \\
\hline & 6 & 12 & 18 & & \\
\hline \multicolumn{6}{|l|}{ Sieve $^{1}$} \\
\hline 19-mm & $4.5^{\mathrm{c}}$ & $8.0^{\mathrm{b}}$ & $15.6^{\mathrm{a}}$ & 0.74 & $<0.01$ \\
\hline 8-mm & $56.2^{c}$ & $66.2^{\mathrm{a}}$ & $63.1^{b}$ & 0.84 & $<0.01$ \\
\hline $1.18-\mathrm{mm}$ & $34.2^{\mathrm{a}}$ & $22.8^{\mathrm{b}}$ & $17.7^{\mathrm{c}}$ & 0.59 & $<0.01$ \\
\hline Bottom pan & $4.2^{\mathrm{a}}$ & $3.2^{\mathrm{b}}$ & $2.8^{\mathrm{b}}$ & 0.08 & $<0.01$ \\
\hline $\mathrm{MPL}^{2}, \mathrm{~mm}$ & $7.7^{\mathrm{c}}$ & $9.3^{\mathrm{b}}$ & $10.7^{\mathrm{a}}$ & 0.11 & $<0.01$ \\
\hline Sgm & $2.15^{\mathrm{a}}$ & $2.06^{\mathrm{b}}$ & $2.12^{\mathrm{ab}}$ & 0.016 & $<0.01$ \\
\hline
\end{tabular}

${ }^{a-c}$ Means in the same row with different superscripts differ by Tukey test $(P \leq 0.05)$.

${ }^{1}$ Percentage of particles retained on each sieve (as fed basis) of Penn State Particle Size Separator.

${ }^{2}$ Mean particle length calculated as described by Kononoff et al. (2003).

The length of storage displayed changes in WPCS particle size distribution (Table 6). The long ensiling time period (140 d) increased the amount of particles in the 19-mm PSPS sieve in comparison with the other ensiling time periods. In the $8-\mathrm{mm}$ sieve, both ensiling times (short and long) had higher percentages of particles retained than when unfermented. The MPL increased along the length of storage (7.9, 9.5 and 10.4-mm). 
Table 6. Effect of ensiling time on particle size distribution and mean particle length in WPCS harvested with a self-propelled forage harvester

\begin{tabular}{|c|c|c|c|c|c|}
\hline \multirow[b]{2}{*}{ Item } & \multicolumn{3}{|c|}{ Ensiling time } & \multirow[b]{2}{*}{ SEM } & \multirow[b]{2}{*}{$P$-value } \\
\hline & 0 & 35 & 140 & & \\
\hline \multicolumn{6}{|l|}{ Sieve $^{1}$} \\
\hline 19-mm & $7.8^{\mathrm{b}}$ & $7.8^{\mathrm{b}}$ & $11.7^{\mathrm{a}}$ & 0.74 & $<0.01$ \\
\hline 8-mm & $54.0^{\mathrm{b}}$ & $66.1^{\mathrm{a}}$ & $65.4^{\mathrm{a}}$ & 0.84 & $<0.01$ \\
\hline $1.18-\mathrm{mm}$ & $31.5^{\mathrm{a}}$ & $22.4^{\mathrm{b}}$ & $20.8^{c}$ & 0.59 & $<0.01$ \\
\hline Bottom pan & 5.4 & 2.8 & 2.1 & 0.08 & $<0.01$ \\
\hline $\mathrm{MPL}^{2}, \mathrm{~mm}$ & $7.9^{c}$ & $9.5^{\mathrm{b}}$ & $10.4^{\mathrm{a}}$ & 0.11 & $<0.01$ \\
\hline Sgm & $2.28^{\mathrm{a}}$ & $2.05^{\mathrm{b}}$ & $2.00^{\mathrm{b}}$ & 0.016 & $<0.01$ \\
\hline
\end{tabular}

${ }^{a-c}$ Means in the same row with different superscripts differ by Tukey test $(P \leq 0.05)$.

${ }^{1}$ Percentage of particles retained on each sieve (as fed basis) of Penn State Particle Size Separator.

${ }^{2}$ Mean particle length calculated as described by Kononoff et al. (2003).

There was an interaction between TLOC and ensiling time for particles in the PSPS pan $(P=0.01$; Figure 1). Distinct amounts in the pan were observed at time 0 among TLOC settings. Nonetheless, at short and long ensiling time periods, there was a rise in particles in the pan only for the 6-mm TLOC. For the other variables no interactions occurred $(P>0.14)$.

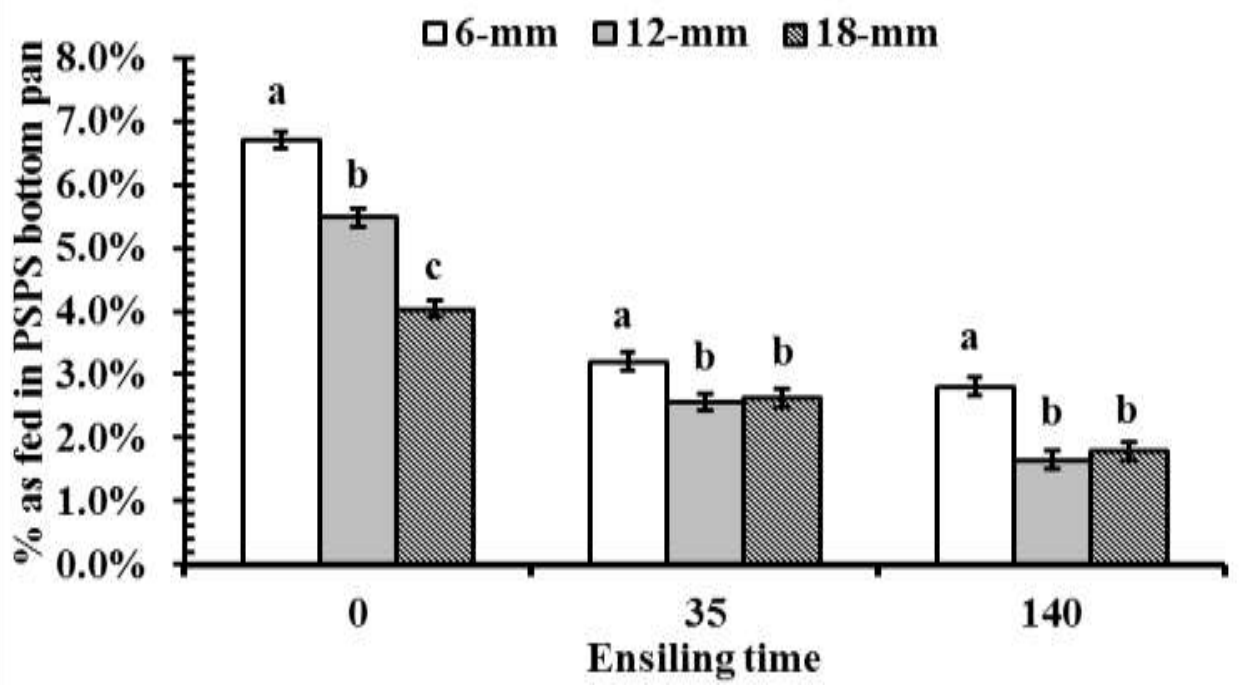

Figure 1. Interaction between TLOC and ensiling time for particles in the Penn State Particle Size Separator bottom pan $(P=0.01 ; \mathrm{SEM}=0.08)$

The kernel particle size distribution changed through TLOC settings (Table 7). In the upper sieve, the TLOC of $6(14.9 \%)$ and 12-mm (17.0\%) retained lower percentages than 18$\mathrm{mm}(20.4 \%)$. In the next sieve $(4.75 \mathrm{~mm})$, there was a rise of $2.5 \%$ units of particles retained for the $18-\mathrm{mm}$ in relation to 6-mm TLOC. However the 12-mm was not distinguished from other treatments. The TLOC impacted the particle size distribution in the 3.35, 2.36, 1.70, 
1.18-mm sieves and pan differently. The kernels smaller than 4.75-mm increased (57.1, 60.8 and $65.0 \%$ ) accordingly of the reduction of TLOC. However, only 6-mm TLOC was able to impact GMPS and surface area. CSPS differed between 6 and 18-mm of TLOC.

Table 7. Effect of theoretical length of cut on kernel fraction particle size distribution, geometric mean particle size (GMPS), surface area and processing score in WPCS harvested with a self-propelled forage harvester

\begin{tabular}{|c|c|c|c|c|c|}
\hline \multirow[b]{2}{*}{ Item } & \multicolumn{3}{|c|}{ TLOC } & \multirow[b]{2}{*}{ SEM } & \multirow[b]{2}{*}{$P$-value } \\
\hline & 6 & 12 & 18 & & \\
\hline \multicolumn{6}{|l|}{ Sieve $^{1}, \mathrm{~mm}$} \\
\hline 6.7 & $14.9^{\mathrm{b}}$ & $17.0^{\mathrm{b}}$ & $20.4^{\mathrm{a}}$ & 0.78 & $<0.01$ \\
\hline 4.75 & $20.0^{\mathrm{b}}$ & $22.2^{\mathrm{ab}}$ & $22.5^{\mathrm{a}}$ & 0.66 & 0.03 \\
\hline 3.35 & $13.2^{\mathrm{c}}$ & $15.8^{\mathrm{a}}$ & $14.3^{\mathrm{b}}$ & 0.23 & $<0.01$ \\
\hline 2.36 & $19.6^{\mathrm{a}}$ & $18.9^{\mathrm{ab}}$ & $17.6^{\mathrm{b}}$ & 0.40 & $<0.01$ \\
\hline 1.70 & $10.8^{\mathrm{a}}$ & $8.8^{\mathrm{b}}$ & $8.0^{\mathrm{c}}$ & 0.21 & $<0.01$ \\
\hline 1.18 & $7.1^{\mathrm{a}}$ & $5.3^{\mathrm{b}}$ & $5.3^{\mathrm{b}}$ & 0.24 & $<0.01$ \\
\hline 0.59 & $7.8^{\mathrm{a}}$ & $6.4^{\mathrm{b}}$ & $6.3^{\mathrm{b}}$ & 0.22 & $<0.01$ \\
\hline Pan & $6.5^{\mathrm{a}}$ & $5.3^{\mathrm{b}}$ & $5.4^{\mathrm{b}}$ & 0.21 & $<0.01$ \\
\hline$\%<4.75^{2}$ & $65.0^{\mathrm{a}}$ & $60.8^{\mathrm{b}}$ & $57.1^{\mathrm{c}}$ & 1.01 & $<0.01$ \\
\hline GMPS, $\mu \mathrm{m}$ & $2908.1^{\mathrm{b}}$ & $3206.7^{\mathrm{a}}$ & $3346.6^{\mathrm{a}}$ & 49.07 & $<0.01$ \\
\hline Surface area, $\mathrm{cm}^{2} / \mathrm{g}$ & $20.0^{\mathrm{a}}$ & $18.5^{\mathrm{b}}$ & $18.1^{\mathrm{b}}$ & 0.27 & $<0.01$ \\
\hline Processing score $^{3}$ & $60.4^{\mathrm{a}}$ & $52.8^{\mathrm{ab}}$ & $51.1^{\mathrm{b}}$ & 2.37 & 0.02 \\
\hline
\end{tabular}

$\stackrel{a-b}{a-b e a n s ~ i n ~ t h e ~ s a m e ~ r o w ~ w i t h ~ d i f f e r e n t ~ s u p e r s c r i p t s ~ d i f f e r ~ b y ~ T u k e y ~ t e s t ~}(P \leq 0.05)$.

${ }^{1}$ Percentage of particles retained on each sieve (DM basis).

${ }^{2}$ Proportion of kernel fraction passing through a $4.75-\mathrm{mm}$ sieve.

${ }^{3}$ Percent of starch passing a $4.75-\mathrm{mm}$ sieve; processing score was measured as described by Ferreira and Mertens (2005).

The impact of fermentation at kernel particle size distribution is in Table 8. In summary, both 35 and $140 \mathrm{~d}$ of ensiling reduced particles higher than 6.7-mm and increased percentage of kernels retained in the sieves with apertures of $1.7,1.18$ and $0.59-\mathrm{mm}$. 
Table 8. Effect of ensiling time on kernel fraction particle size distribution, geometric mean particle size (GMPS), surface area, and processing score in WPCS harvested with a self-propelled forage harvester

\begin{tabular}{|c|c|c|c|c|c|}
\hline \multirow[b]{2}{*}{ Item } & \multicolumn{3}{|c|}{ Ensiling time } & \multirow[b]{2}{*}{ SEM } & \multirow[b]{2}{*}{$P$-value } \\
\hline & 0 & 35 & 140 & & \\
\hline \multicolumn{6}{|l|}{ Sieve $^{1}, \mathrm{~mm}$} \\
\hline 6.7 & $21.7^{\mathrm{a}}$ & $16.1^{\mathrm{b}}$ & $14.6^{\mathrm{b}}$ & 0.78 & $<0.01$ \\
\hline 4.75 & 20.7 & 22.1 & 21.9 & 0.66 & 0.30 \\
\hline 3.35 & 14.7 & 14.5 & 14.0 & 0.23 & 0.13 \\
\hline 2.36 & 18.8 & 18.4 & 19.0 & 0.40 & 0.55 \\
\hline 1.70 & $8.1^{\mathrm{b}}$ & $9.4^{\mathrm{a}}$ & $10.0^{\mathrm{a}}$ & 0.21 & $<0.01$ \\
\hline 1.18 & $4.8^{\mathrm{b}}$ & $6.3^{\mathrm{a}}$ & $6.6^{\mathrm{a}}$ & 0.24 & $<0.01$ \\
\hline 0.59 & $6.0^{\mathrm{b}}$ & $7.2^{\mathrm{a}}$ & $7.3^{\mathrm{a}}$ & 0.22 & $<0.01$ \\
\hline Pan & 5.0 & 5.9 & 6.6 & 0.21 & $<0.01$ \\
\hline$\%<4.75^{2}$ & $57.6^{\mathrm{b}}$ & $61.8^{\mathrm{a}}$ & $63.5^{\mathrm{a}}$ & 1.01 & $<0.01$ \\
\hline GMPS, $\mu \mathrm{m}$ & $3420.0^{\mathrm{a}}$ & $3059.5^{b}$ & $2981.8^{b}$ & 49.07 & $<0.01$ \\
\hline Surface area, $\mathrm{cm}^{2} / \mathrm{g}$ & $17.5^{\mathrm{b}}$ & $19.3^{\mathrm{a}}$ & $19.7^{\mathrm{a}}$ & 0.27 & $<0.01$ \\
\hline Processing score ${ }^{3}$ & $49.0^{\mathrm{b}}$ & $56.4^{\mathrm{ab}}$ & $58.9^{\mathrm{a}}$ & 2.37 & 0.02 \\
\hline
\end{tabular}

There was a trend for interaction between TLOC and ensiling time for kernels in the pan $(P=0.10 ;$ Figure 2). In unfermented samples and $140 \mathrm{~d}$ of ensiling, the TLOC of $6-\mathrm{mm}$ promoted the greatest amount retained in the pan, however at $35 \mathrm{~d}$ no differences occurred among treatments. A higher percentage of kernels smaller than 4.75-mm and surface area were observed for 35 and $140 \mathrm{~d}$ in comparison with unfermented samples. The GMPS was reduced in both ensiling times. The CSPS was different only between unfermented and $140 \mathrm{~d}$ of ensiling (49.0 vs. 58.9\%). There were no more interactions $(P>0.12$; interaction's $P$ values were not shown in tables or figures). 
ㅁ6-mm ㅁ12-mm 图18-mm

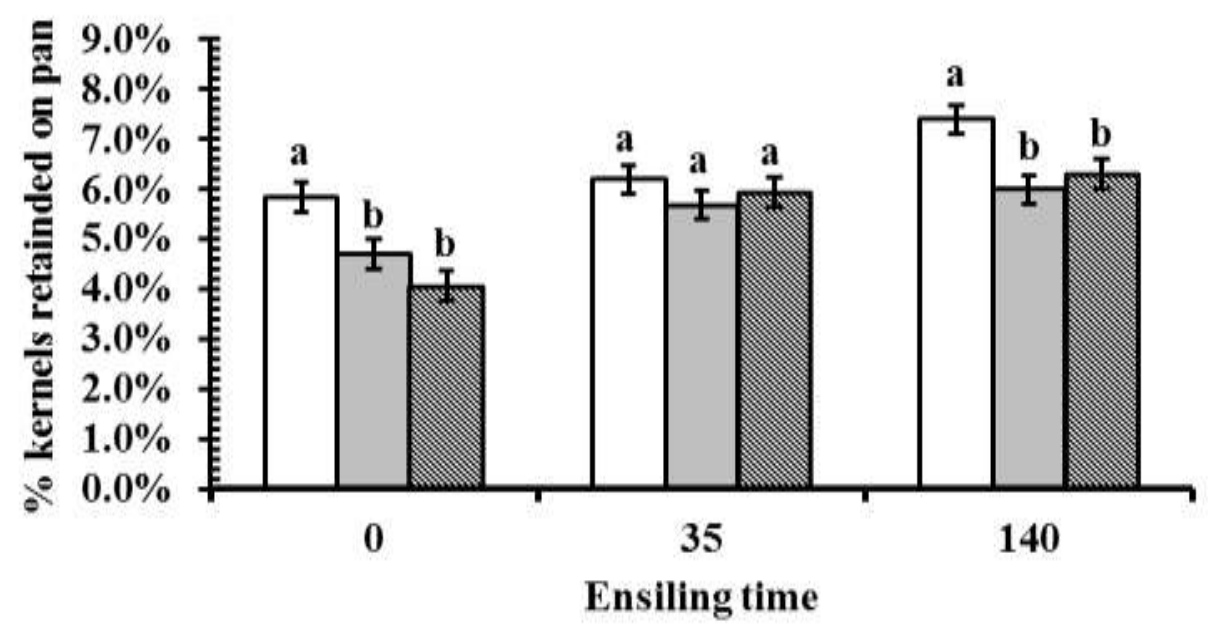

Figure 2. Interaction between TLOC and ensiling time for kernels retained in the pan $(P=0.10$; SEM $=$ $0.21)$

\subsection{DISCUSSION}

The nutrient composition of whole-plant corn (\% DM) - 30.6\% starch and $43.6 \%$ NDF -represents high quality corn silage for international standards (Owens, 2014). The lack of differences on particle size distribution and MPL between TLOC of 3 and 6-mm was not expected in PTFH. The TLOC is controlled by the peripheral speed of the feed rolls relative to the speed of the cutter head and the number of cutter head knives (Shinners, 2003). The number of knives inside PTFH and speed of the cutter head were the same in both of these treatments. The only way to change TLOC is by altering the peripheral speed of the feed rolls relative to the cutterhead speed by changing the drive sprockets or gears driving the feedrolls (Shinners, 2003).

The company's gear setting recommendations to reach different particle size at TLOC of 3 and 6-mm did not achieve this objective. However, the TLOC of 9-mm promoted a rise of particles retained on the top 2 PSPS sieves, and as a consequence, the MPL increased. Shinners et al. (2000) evaluated the effect of 3 TLOC settings (12.7, 19.0 and 25.4$\mathrm{mm}$ ) on WPCS particle size in a PTFH with a KP at a roll gap of $1-\mathrm{mm}$. In this trial the particle size was determined by an apparatus and procedure described in American Society of Agricultural Engineers - ASAE standard S424.1 (ASAE, 1998). A higher percentage of particles retained in a $18-\mathrm{mm}$ sieve was observed followed by a rise in MPL from 11.0 to 13.4-mm. 
In the second experiment, we observed that the rise of TLOC from 6 to 18 -mm led to a greater percentage of longer particles (> 19-mm) and MPL. Johnson et al. (2003) also reported increments of MPL and the percentage of longer particles in response to different TLOC settings $(11.1,27.8$, and $39.7 \mathrm{~mm})$ for WPCS harvested by SPFH. Ferraretto et al. (2015a) studied the impact of 3 hybrids, at 2 maturities (milk-line and 7-d later) and chopped at 2 TLOC settings $(6.4-\mathrm{mm}$ or $19.5-\mathrm{mm})$ in particle size and processing score. Particle size was increased with longer TLOC settings as expected. The samples harvested at 6.4-mm TLOC, on average, showed less retention in the coarse (3.5 vs. 9.0\%) and medium (52.9 vs. $58.1 \%$ ) sieves, but more material retained in the fine sieve (41.3 vs. $30.6 \%)$ than $19.5-\mathrm{mm}$ TLOC samples. Material in the bottom pan did not differ between TLOC settings and averaged $2.3 \%$. The kernel processing score varied among all samples, but it was not affected by the TLOC setting.

The ensiling time affected the WPCS particle distribution only in the second experiment. The longest ensiling time had a higher percentage of particles retained in the top 2 PSPS sieves, therefore the MPL increased. At d 35 of ensiling, there was an increase of particles only in the 8-mm PSPS sieve. Johnson et al. (2003) observed an increase in MPL and particles retained in the $19-\mathrm{mm}$ sieve with ensiling period. These authors suggested that compaction of the forage in the silo may have altered the physical characteristics of the forage (flattened some of the particles), making it difficult for some particles to pass through the screens in the PSPS. The reason for the interaction between TLOC and ensiling time for particles smaller than 1.18 - $\mathrm{mm}$ is unknown.

Reducing TLOC can be a possible strategy for improving kernel breakage in PTFH without a KP (Johnson et al., 1999). Dias Junior et al. (2015) reported a reduction in visible intact kernels in WPCS harvested by PTFH when the TLOC was reduced from 8.5-mm to 3$\mathrm{mm}$. In the present study was expected a reduction of kernel particle size for the smallest TLOC, however, it did not happen in the first experiment. The values of CSPS were below $50 \%$ for PTFH and from 51.1 to $60.4 \%$ for SPFH samples. In this way, they can be classified as inadequately and adequately processed, respectively, according to Shinners and Holmes (2013). The hybrid had a high percentage of vitreous endosperm $(65 \%)$ which is related to kernel hardness (Correa et al., 2002) and can make kernels more difficult to be broken by the harvester processors (Ferraretto et al. 2018). It could be worse for a PTFH without a KP that depends on the cutting knives for kernel breakage. Moreover, kernel virtuousness traditionally increases throughout the maturity of WPCS (Philippeau and MichaletDoreau,1997) which may explain the depression of TTSD for cows fed with very dried 
WPCS (> 40\% DM) even when processed (Ferraretto and Shaver, 2012). This effect may occur in Brazilian vitreous corn hybrids even earlier than 40\% DM.

The common TLOC used for SPFH is 19-mm in USA (Shinners, 2003; Kung and Muck, 2017). However, even within a range of TLOC below this target (e.g. 12 and 18-mm), the CSPS was not good. Through a meta-analysis of 24 studies, Ferraretto and Shaver et al. (2012) evaluated the impact of TLOC and kernel processing in starch digestibility. Authors have reported decreased ruminal starch digestibilty when WPCS was harvested with long TLOC (>32-mm) and proposed that the long fiber fraction could reduce kernel breakage during processing. This effect might be occuring at TLOC setting below 32-mm for vitreous corn hybrid. Research should be focused on evaluating strategies (i.e new KP, roll speed differetial, roll gap and TLOC settings) within a wide range of maturities to optmize kernel processing in vitreous endosperm hybrids.

The ensiling time of either 35 or $140 \mathrm{~d}$ were able to reduce GMPS even in poor processed silage (CSPS $<26.4 \%$ ) harvested by PTFH. As a consequence, the surface area and proportion of kernels smaller than 4.75-mm increased. The same effect was observed for SPFH samples with adequate CSPS. This impact of ensiling time for these kernel fraction variables (GMPS and surface area) of WPCS had not been reported in the literature yet. Futhermore, Dias Júnior et al. (2016) observed a strong relationship between these kernel variables and ruminal DM dissapperence in unfermented kernels at different times of incubation (3, 6, 9 and $12 \mathrm{~h}$ ), thus an effect of ensiling time to improve DM digestibility through reduction of kernel particle size is plausible. Ferraretto et al. (2015b) reported, across 2 experiments, an increase of 7 to $10 \%$ units for CSPS in WPCS ensiled for at least $30 \mathrm{~d}$ and up to $240 \mathrm{~d}$. In the present trial, the CSPS was not altered by ensiling time in PTFH samples, but was increased by $9.9 \%$ units for $140 \mathrm{~d}$ of storage in comparison with unfermented samples. These findings suggest that ensiling time of at least $140 \mathrm{~d}$ may be a good strategy to increase kernel damage.

Hoffman et al. (2011) reported physicalchemical alterations in high-moisture corn silage due to longer ensiling time (240 d). A reduction of $\alpha, \gamma, \delta$, and $\beta$ prolamin-zein subunits of the starch-protein matrix was observed followed by a rise of buffer-soluble CP at $240 \mathrm{~d}$ of ensiling in comparison with unfermented samples. Through electron micrograph pictures, the authors demonstrated that starch-zein protein clusters within particles of highmoisture corn were dissosiated. This effect of proteolysis may be a possible explanation for the alterations in GMPS, surface area, propotion of kernels smaller than 4.75-mm and CSPS. 
However, in the present study no analyses of these chemical components were performed to support this premise.

\subsection{CONCLUSIONS}

In PTFH, the TLOC of 3 and 6-mm promoted no differences in WPCS particle size distribution. However, the TLOC of 9-mm increased the MPL. The rise of TLOC in SPFH led to a higher MPL and percentage of long particles (> 19-mm). The ensiling time increased MPL and longer particles only for WPCS harvested by SPFH. The strategy of reducing TLOC in SPFH was efficient to improve the percentage of kernels smaller than $4.75-\mathrm{mm}$. Furthermore, The TLOC of 6-mm led to the best kernel processing in SPFH. The ensiling time reduced the particle size of kernel fraction for both forage harvesters. The CSPS increased only for $140 \mathrm{~d}$ of ensiling and when WPCS was harvested with SPFH. These findings suggest that ensiling time and low TLOC in SPFH (6-mm) may be good strategies to increase kernel damage in Brazilian vitreous corn hybrid silages.

\section{LITERATURE CITED}

AOAC International. 2012. Official Methods of Analysis. 19th ed. AOAC International, Arlington, VA.

ASAE Standards, 44th Ed. 1998. S424.1. Method of determining and expressing particle size of chopped forage materials by screening. St. Joseph, Mich.: ASAE.

Bal, M. A., R. D. Shaver, A. G. Jirovec, K. J. Shinners, and J. G. Coors. 2000. Crop processing and chop length of corn silage: Effects on intake, digestion, and milk production by dairy cows. J. Dairy Sci. 83:1264-1273.

Baker, S., and T. Herrman. 2002. Evaluating particle size. MF-2051. Kansas State Univ., Manhattan.

Bernardes, T. F., and A. C. Rego. 2014. Study on the practices of silage production and utilization on Brazilian dairy farms. J. Dairy Sci. 97:1852-1861.

Bernardes, T. F., J. L. P. Daniel, A. T. Adesogan, T. A. McAllister, P. Drouin, L. G. Nussio, P. Huhtanen, G. F. Tremblay, G. Bélanger, and Y. Cai. 2018. Silage review: Unique challenges of silages made in hot and cold regions. J. Dairy Sci. 101:4001-4019.

Correa, C. E. S., R. D. Shaver, M. N. Pereira, J. G. Lauer, and K. Kohn. 2002. Relationship between corn vitreousness and ruminal in situ starch degradability. J. Dairy Sci. 85:30083012. 
Daniel, J. L. P., Bernardes, T. F., C. C. Jobim, P. Schmidt, and L. G. Nussio.Production and utilization of silages in tropical areas with focus in Brazil. 2019. Grass Forage Sci. 1-13.

Dombrink-Kurtzman, M. A., and J. A. Bietz. 1993. Zein composition in hard and soft endosperm of maize. Cereal Chem. 70:105-108.

Dias Junior, G. S., N. N. Morais Junior, R. F. Lima, F. F. Cardoso, O. F. Zacaroni, R. A. N. Pereira, and M. N. Pereira. 2015. Effect of KP and theoretical length of cut on physical characteristics of forage corn harvested with one row harvester. J. Dairy Sci. 98(Suppl. 2):689 (Abstr.)

Dias Junior, G. S., L. F. Ferraretto, G. G. S. Salvati, L. C. de Resende, P. C. Hoffman, M. N. Pereira, and R. D. Shaver. 2016. Relationship between processing score and kernelfraction particle size in whole-plant corn silage. J. Dairy Sci. 99:2719-2729.

Der Bedrosian, M. C., L. Kung Jr., and K. E. Nestor Jr.. 2012. The effects of hybrid, maturity and length of storage on the composition and nutritive value of corn silage. J. Dairy Sci. 95:5115-5126.

Ferraretto, L. F., and R. D. Shaver. 2012. Meta-analysis: Impact of corn silage harvest practice on intake, digestion and milk production by dairy cows. Prof. Anim. Sci. 28:141149.

Ferraretto, L. F., P. M. Crump, and R. D. Shaver. 2015a. Effect of ensiling time and exogenous protease addition to whole-plant corn silage of various hybrids, maturities and chop lengths on nitrogen fractions and ruminal in vitro starch digestibility. J. Dairy Sci. 98:8869-8881.

Ferraretto, L. F., G. S. Dias Junior, L. C. de Resende, and R. D. Shaver. 2015b. Effect of ensiling on kernel processing score in whole-plant corn silage harvested with varied processors and settings. J. Dairy Sci. 98(Suppl. 2):689. (Abstr.)

Ferraretto, L. F., R. D. Shaver, and B. D. Luck. 2018. Silage review: Recent advances and future technologies for whole-plant and fractionated corn silage harvesting. J. Dairy Sci. 101:3937-3951.

Ferreira, G., and D. R. Mertens. 2005. Chemical and physical characteristics of corn silages and their effects on in vitro disappearance. J. Dairy Sci. 88:4414-4425.

Hall, M. B. 2015. Determination of dietary starch in animal feeds and pet food by an enzymatic-colorimetric method. Collaborative study. J. AOAC Int. 98:397-409.

Hoffman, P. C., N. M. Esser, R. D. Shaver, W. Coblentz, M. P. Scott, A. L. Bodnar, R. Schmidt, and B. Charely. 2011. Influence of inoculation and storage time on alteration of the starch-protein matrix in high moisture corn. J. Dairy Sci. 94:2465-2474. 
Johnson, L., J. H. Harrison, C. Hunt, K. Shinners, C. G. Doggett, and D. Sapienza. 1999. Nutritive value of corn silage as affected by maturity and mechanical processing: A contemporary review. J. Dairy Sci. 82:2813-2825.

Johnson, L. M., J. H. Harrison, D. Davidson, W. C. Mahanna, and K. Shinners. 2003. Corn silage management: Effects of hybrid, chop length, and mechanical processing on digestion and energy content. J. Dairy Sci. 86:208-231.

Kung Jr., L., and R. E. Muck. Silage harvesting and storage. 2017. Pages 723-738 in Large Dairy Herd Management (3oed.) edited by D. K. Beede. 1376 p.

Mertens, D. R. 1997. Creating a system for meeting the fiber requirements of dairy cows. J. Dairy Sci. 80:1463-1481.

Owens, F. 2014. New technologies in forage varieties and production. Pages 103-121 in Proc. Tri-State Dairy Nutr.Conf., Ft. Wayne, IN. Ohio State Univ., Columbus.

Philippeau, C., and B. Michalet-Doreau. 1997. Influence of genotype and stage of maturity of maize on rate of ruminal starch degradation. Anim. Feed Sci. Technol. 68:25-35.

Shinners, K. J., A. G. Jirovec, R. D. Shaver, and M. Bal. 2000. Processing whole-plant corn silage with crop processing rolls on a pull-type forage harvester. Appl. Eng. Agric. 16:323-331.

Shinners, K. J. 2003. Engineering principles of silage harvesting equipment. Pages 361-403 in Silage Science and Technology. D. R. Buxton, R. E. Muck, and H. J. Harrison, ed. ASA, CSA, and SSSA, Madison, WI.

Shinners, K. J., and B. J. Holmes. 2013. Making sure your KP is doing its job. Focus on Forage, 15:1-3. Accessed May 20, 2018. http:// fyi .uwex .edu/ forage/ files/ 2014/ 01/ Kernel Processing -FOF .pdf.

Wiles, P. G., I. K. Gray, and R. C. Kissling. 1998. Routine analyses of protein by Kjeldahl and Dumas methods: Review and inter-laboratory study using dairy products. J. AOAC Int. 81:620-632. 


\title{
3. HOW DOES A NOVEL PULL-TYPE FORAGE HARVESTER WITH KERNEL PROCESSOR CHOP A VITREOUS CORN HYBRID?
}

\begin{abstract}
The objective of this study was to evaluate the impact of two types of forage harvesters and two TLOC settings on the physical characteristics of WPCS. A vitreous corn silage hybrid (BM 709, Sementes Biomatrix) was cultivated and harvested when whole-corn plant DM achieved 34.8\%. The whole-plant was harvested with a conventional pull-type forage harvester (PTFH) without kernel processor (KP) at 6 and 10 of theoretical lengths of cut (TLOC) or by a new PTFH with KP at same TLOC settings. Whole-plant corn silage (WPCS) samples were stored for $35 \mathrm{~d}$. Vitreousness, measured by dissection in unfermented kernels, averaged $62.4 \%$. Data were analyzed as completely randomized design in a factorial arrangement: 2 harvesters $\times 2$ TLOC using the procedure MIXED of SAS (SAS Institute Inc., Cary, NC). The model included the fixed effects of harvester, TLOC and the interaction harvester $\times$ TLOC. The follow differences occurred only in TLOC of $10-\mathrm{mm}$. KP reduced the material above the $19-\mathrm{mm}$ sieve from 4.7 to $1.8 \%$ which, in turn, increased the percentage of particles below 8 -mm sieve while MPL was decreased. This TLOC displayed the highest value of material retained in the $8-\mathrm{mm}$ and the lowest values in the 4-mm sieve for unprocessed WPCS. Kernel processing and short TLOC led to a rise in particles retained in a 4-mm sieve. KP increased the percentage of kernels smaller than 4.75-mm from 56.4 to $80.0 \%$ and the starch content below $8-\mathrm{mm}$ sieve. The short TLOC and kernel processing, together, led to a reduction of kernel geometrical mean particle size (GMPS) followed by an increase of surface area. The new PTFH with KP promoted more extensive and effective kernel breakage. The impact of this harvester in WPCS particle size distribution was pronounced in the TLOC of 10-mm which led to a drop in MPL. The reduction of TLOC for both forage harvesters may be a good strategy to fracture corn kernels for WPCS at $34.8 \%$ of DM.
\end{abstract}

Keywords: Kernel processing; Vitreous endosperm; Geometrical mean particle size

\subsection{INTRODUCTION}

In 2012, a survey performed with 260 dairy farmers from 23 states in Brazil indicated that the most used source of forage was whole-plant corn silage (WPCS; Bernardes and Rego, 2014). The WPCS can provide a greater production of low-cost starch per hectare with a high concentration of metabolizable energy in areas where the land is suitable for its 
cultivation (Wilkinson and Rinne, 2018). Furthermore, the rapid harvest and ease of ensiling (Nigon et al., 2016) has made the crop a popular choice for dairy farmers.

Despite the increase in custom contractors offering self-propelled forage harvester (SPFH) services (Daniel et al., 2019), the adoption of pull-type forage harvesters (PTFH) by Brazilian dairy farmers is still very common (Bernardes and Rego, 2014). Until two years ago there was no PTFH with kernel processor (KP) on the market. This is a current concern as most cultivated hybrids have a higher proportion of vitreous endosperm in the kernel (Correa et al., 2002; Bernardes et al., 2018) which is more difficult to fracture during the harvesting process (Ferraretto et al. 2018). In this scenario, reducing the theoretical length of cut (TLOC) may be a possible way to optimize the kernel breakage by cutting knives (Johnson et al., 1999).

In the USA, the common TLOC settings for unprocessed WPCS are between 10 and 13-mm and about 19-mm for processed WPCS (Shinners et al., 2003; Kung and Muck, 2017). Recently, a new model of PTFH with a KP was launched in the Brazilian market; however no studies to prove its kernel processing efficiency have been performed yet. The hypothesis of this study was that in order to achieve adequate kernel processing in the vitreous endosperm hybrid, a PTFH with KP and lower TLOC would be required. The objective of this study was to evaluate the impact of two types of forage harvesters and two TLOC settings on the physical characteristics of WPCS.

\subsection{MATERIALS AND METHODS}

Three hectares of a vitreous corn silage hybrid (BM 709, Sementes Biomatrix, Rio Claro, São Paulo, Brasil) were cultivated on August 1st, 2017 at a density of 62500 seeds per hectare at the Federal Institute of Espírito Santo - Itapina Campus (Colatina, ES, Brazil). The harvesting occurred on December 12,2017, at approximately 34.8\% DM when plants had half of milk line stage of kernel maturity. The field was harvested in alternating strips in an attempt to keep similar nutrient composition among the treatments. The treatments were performed during the harvesting. Corn kernel vitreousness was determined by manual dissection (Dombrink-Kurtzman and Bietz, 1993) in fifteen ears collected from the corn crop and followed the procedure described by Correa et al. (2002).

A JF C240 PTFH without KP (PT; JF Máquinas Agrícolas, Itapira, Sao Paulo, Brazil) and a JM4200 PTFH with KP (PTK; 2-mm of roll gap; Jumil, Batatais, Sao Paulo, Brazil) set for a TLOC at 6 or $10-\mathrm{mm}$ were used to harvest treatments. The samples collected 
during harvest were vacuum-sealed in four plastic bags $(15 \times 35 \mathrm{~cm}$, width $\times$ length $)$ and stored for $35 \mathrm{~d}$. This experiment consisted of 4 treatments ( 2 harvesters and 2 lengths of cut) and 36 plastic bag mini-silos (4 replications per treatment). Mini-silos were stored at room temperature (approximately $25^{\circ} \mathrm{C}$ ) in the dark until reaching the targeted ensiling time.

Each WPCS sample was placed in a bucket, homogenized manually and divided in 3 equal subsamples. The first subsample, as-fed whole-plant samples were used for determination of particle size distribution using Penn State Particle Size Separator (PSPS). The PSPS procedure was conducted manually using 3 sieves (19, 8 and 4-mm) and a bottom pan. The mean particle length (MPL) was calculated according of Heinrichs (2013). The particles retained in each sieve were dried at $60^{\circ} \mathrm{C}$ for $48 \mathrm{~h}$ in a forced-air oven and then ground to pass through a 1-mm Wiley mill screen (Arthur H. Thomas). Starch content was analyzed as described to Hall et al. (2015) and the particle starch content retained in each PSPS sieve was calculated.

The second subsample was dried at $60^{\circ} \mathrm{C}$ for $48 \mathrm{~h}$ in a forced-air oven and then ground to pass through a 1-mm Wiley mill screen (Arthur H. Thomas). The DM (method 942.05) and ether extract (method 2003.05) were determined as described by AOAC International (2012). Concentration of CP was determined as $\mathrm{N} \times 6.25$ after analysis with a $\mathrm{N}$ analyzer (Leco FP-2000; Leco Corp., St. Joseph, MI, USA) by the Dumas method (Wiles et al., 1998).The NDF was analyzed using a TE-149 fiber analyzer (TECNAL Equipamentos para Laboratórios, Piracicaba, Brazil) with heat-stable $\alpha$-amylase and sodium sulfite (method 2002.04, AOAC, 2012). Starch was analyzed according to Hall et al. (2015). This data was used only for the description of whole-plant corn nutritional composition.

The third subsample, kernel and stover fractions were separated by a hydrodynamic separation procedure (Savoie et al., 2004). This method is based on differences in buoyancy between the kernels and stover. Because all samples were fermented for at least $35 \mathrm{~d}$, which is thought to make the separation process more difficult, all samples were dried in a forced-air oven set at $60^{\circ} \mathrm{C}$ for $48 \mathrm{~h}$ prior to immersion in water as recommended by Savoie et al. (2004). Each sample of approximately $400 \mathrm{~g}$ of DM was placed in a 10-L rectangular tub containing $7 \mathrm{~L}$ of water. Each dried sample was gently agitated manually for 2 min such that the entire sample was submerged in water. After $2 \mathrm{~min}$, the stover fraction which floats, due to a lower density than water, was removed gently using a small 1.18-mm sieve (Savoie et al., 2004). After separation, the kernel-fraction was transferred to aluminum plates, re-dried at $60^{\circ} \mathrm{C}$ for $48 \mathrm{~h}$ in a forced-air oven and dry-sieved using a Tyler Ro-Tap Shaker (model RX29, Tyler, Mentor, $\mathrm{OH}$ ) with a set of 9 sieves with nominal square apertures of $9.50,6.70$, 
$4.75,3.35,2.36,1.70,1.18,0.59-\mathrm{mm}$ and bottom pan. The geometrical mean particle size (GMPS; $\mu \mathrm{m})$ and surface area $\left(\mathrm{cm}^{2} / \mathrm{g}\right)$ were calculated using a log normal distribution (Baker and Herrman, 2002) as described by Dias Junior et al. (2016). The proportion of kernels smaller than $4.75-\mathrm{mm}$ was calculated by the sum of percentages retained at 3.35, 2.36, 1.70, 1.18 and 0.59-mm sieves and pan (Dias Junior et al., 2016).

\subsubsection{Statistical analysis}

Data were analyzed as completely randomized design in a factorial arrangement: 2 harvesters $\times 2$ TLOC using the procedure MIXED of SAS (SAS Institute Inc., Cary, NC). The model included the fixed effects of harvester, TLOC and the interaction harvester $\times$ TLOC. A mini-silo was used as the experimental unit. Means were determined using the LSMEANS statement and were compared using the Tukey test at $5 \%$ of significance. Statistical significance and trends were considered at $P \leq 0.05$ and $P>0.06$ to $P \leq 0.10$, respectively.

\subsection{RESULTS}

The corn kernel vitreousness of the hybrid was $62.4 \pm 8 \%$ of total endosperm (data not shown in tables or figures). The chemical composition of whole-plant corn was (\% of DM) 9.5 for CP, 4.3 for EE, 44.1 for NDF and 33.2 for starch. The average of DM (\% of as fed) was $34.8 \%$. Harvester $\times$ TLOC interactions were observed $(P<0.04)$ for the percentage of particles retained in 19-mm, in 8-mm and 4-mm sieves (Table 9). There were also interactions to percentage of total material below 8-mm sieve as well as in MPL. The major differences occurred only in TLOC of $10-\mathrm{mm}$. The KP reduced the material above the $19-\mathrm{mm}$ sieve from 4.7 to $1.8 \%$. The greatest value of material retained in the $8-\mathrm{mm}$ and the smallest values in the 4-mm sieve were observed for unprocessed WPCS. In this way, the percentage of particles below 8-mm sieve was elevated by kernel processing and MPL decreased. Kernel processing and short TLOC led to a rise in particles retained in a 4-mm sieve. The geometric standard deviation (Sgm) was affected only by TLOC. 
Table 9. Penn state particle size distribution and mean particle length

\begin{tabular}{lcccccccc}
\hline & \multicolumn{9}{c}{ PT } & \multicolumn{2}{c}{ PTK } & & & \\
\cline { 2 - 7 } Item & 6 & 10 & 6 & 10 & SEM & P Harv & P length & P H*L \\
\hline 19-mm & $1.5^{\mathrm{b}}$ & $4.7^{\mathrm{a}}$ & $1.0^{\mathrm{b}}$ & $1.8^{\mathrm{b}}$ & 0.28 & $<0.01$ & $<0.01$ & $<0.01$ \\
$8-\mathrm{mm}$ & $46.5^{\mathrm{b}}$ & $59.8^{\mathrm{a}}$ & $40.7^{\mathrm{b}}$ & $45.3^{\mathrm{b}}$ & 1.79 & $<0.01$ & $<0.01$ & 0.04 \\
4-mm & $40.2^{\mathrm{a}}$ & $27.7^{\mathrm{b}}$ & $45.0^{\mathrm{a}}$ & $43.3^{\mathrm{a}}$ & 1.66 & $<0.01$ & $<0.01$ & 0.01 \\
Bottom pan & 11.8 & 7.7 & 13.3 & 9.6 & 0.73 & 0.05 & $<0.01$ & 0.81 \\
< 8-mm $^{1}$ & $52.0^{\mathrm{a}}$ & $35.5^{\mathrm{b}}$ & $58.3^{\mathrm{a}}$ & $52.9^{\mathrm{a}}$ & 1.96 & $<0.01$ & $<0.01$ & 0.02 \\
MPL 4 $^{2}, \mathrm{~mm}$ & $7.4^{\mathrm{b}}$ & $9.0^{\mathrm{a}}$ & $6.9^{\mathrm{c}}$ & $7.5^{\mathrm{b}}$ & 0.17 & $<0.01$ & $<0.01$ & 0.02 \\
Sgm $^{3}$ & 1.9 & 1.8 & 1.9 & 1.8 & 0.02 & 0.16 & 0.05 & 0.94 \\
\hline
\end{tabular}

${ }^{1}$ Percentage of particles below of 8 -mm sieve.

${ }^{2}$ Mean particle length calculated as described by Heinrichs (2013).

${ }^{3}$ Geometric standard deviation

Distribution of starch mass is shown in Table 10. The kernel processing impacted the starch content of WPCS retained in all sieves and in the pan. In the 19-mm sieve, the starch content was reduced by kernel processing and TLOC. The opposite happened for the sum of starch content below 8-mm sieve. The PTK displayed a reduction by 12.4 and a rise of $11.8 \%$ units of starch content of material retained in 8-mm and 4-mm sieve, respectively. The starch amount increased in the pan for the shortest TLOC. However, the total amount of starch below 8-mm sieve increased only by kernel processor effect.

Table 10. Starch content by each Penn State Particle Size Separator sieve

\begin{tabular}{|c|c|c|c|c|c|c|c|c|}
\hline \multirow[b]{2}{*}{ Item } & \multicolumn{2}{|c|}{$\mathrm{PT}$} & \multicolumn{2}{|c|}{ PTK } & \multirow[t]{2}{*}{ SEM } & \multirow[t]{2}{*}{ P Harv } & \multirow[t]{2}{*}{ P length } & \multirow[t]{2}{*}{ P H*L } \\
\hline & 6 & 10 & 6 & 10 & & & & \\
\hline 19-mm & 0.6 & 2.0 & 0.2 & 0.6 & 0.37 & 0.04 & 0.04 & 0.26 \\
\hline 8-mm & 55.3 & 58.2 & 44.6 & 44.1 & 1.97 & $<0.01$ & 0.55 & 0.42 \\
\hline 4-mm & 29.2 & 28.5 & 39.2 & 42.0 & 2.43 & $<0.01$ & 0.69 & 0.51 \\
\hline Bottom pan & 14.7 & 11.3 & 15.3 & 14.1 & 1.10 & 0.16 & 0.07 & 0.37 \\
\hline$\%<8-\mathrm{mm}^{1}$ & 43.9 & 39.8 & 55.1 & 55.2 & 1.82 & $<0.01$ & 0.32 & 0.31 \\
\hline
\end{tabular}

${ }^{1}$ Sum of percentages of starch below 8 -mm sieve.

Harvester $\times$ TLOC interactions were observed $(P<0.02)$ for percentage of kernels retained in 3.35- $\mathrm{mm}$ and $2.36-\mathrm{mm}$ sieves and pan (Table 11). There was an increase of kernels retained in the $3.35-\mathrm{mm}$ sieve for processed WPCS in comparison with unprocessed chopped at longest TLOC. This difference did not occur between processed and unprocessed harvested at TLOC of 6-mm and nor for PTK at different TLOC settings. The kernel processing augmented the percentage of particles in 2.36- $\mathrm{mm}$ sieve. In the bottom pan, the processed WPCS harvested at shortest TLOC presented the highest value of material retained. 
The percentage of kernels smaller than 4.75-mm was maximized only on processed WPCS. There was an increase from 56.4 to $80.0 \%$. The short TLOC and kernel processing led to a reduction of GMPS followed by an increase of surface area.

Table 11. Kernel fraction particle size distribution, proportion of kernels smaller than 4.75-mm, geometric mean particle size (GMPS), and surface area of treatments

\begin{tabular}{|c|c|c|c|c|c|c|c|c|}
\hline & \multicolumn{2}{|c|}{ PT } & \multicolumn{2}{|c|}{ PTK } & \multirow[b]{2}{*}{ SEM } & \multirow[b]{2}{*}{ P Harv } & \multirow[b]{2}{*}{$\mathrm{P}$ length } & \multirow[b]{2}{*}{$\mathrm{PH}^{*} \mathrm{~L}$} \\
\hline & 6 & 10 & 6 & 10 & & & & \\
\hline \multicolumn{9}{|l|}{ Sieve $^{1}, \mathrm{~mm}$} \\
\hline 6.7 & 17.6 & 19.7 & 4.6 & 7.2 & 0.92 & $<0.01$ & 0.04 & 0.76 \\
\hline 4.75 & 19.8 & 21.3 & 14.7 & 12.6 & 0.87 & $<0.01$ & 0.71 & 0.12 \\
\hline 3.35 & $13.4^{\mathrm{b}}$ & $11.9^{c}$ & $13.8^{\mathrm{ab}}$ & $14.7^{\mathrm{a}}$ & 0.26 & 0.01 & 0.30 & 0.01 \\
\hline 2.36 & $19.3^{\mathrm{c}}$ & $17.2^{\mathrm{c}}$ & $26.5^{\mathrm{b}}$ & $28.7^{\mathrm{a}}$ & 0.79 & $<0.01$ & 0.96 & 0.02 \\
\hline 1.70 & 8.6 & 8.7 & 13.1 & 13.9 & 0.47 & $<0.01$ & 0.44 & 0.47 \\
\hline 1.18 & 5.6 & 5.5 & 9.2 & 8.5 & 0.27 & $<0.01$ & 0.16 & 0.24 \\
\hline 0.59 & 6.0 & 5.6 & 9.0 & 7.8 & 0.26 & $<0.01$ & 0.02 & 0.16 \\
\hline Pan & $5.8^{\mathrm{b}}$ & $5.3^{\mathrm{b}}$ & $8.8^{\mathrm{a}}$ & $6.0^{\mathrm{b}}$ & 0.31 & 0.01 & 0.01 & 0.01 \\
\hline$\%<4.75^{2}$ & 58.7 & 54.1 & 80.4 & 79.6 & 1.80 & $<0.01$ & 0.18 & 0.32 \\
\hline GMPS, $\mu \mathrm{m}$ & 3284.1 & 3465.2 & 2315.8 & 2552.6 & 89.11 & $<0.01$ & 0.05 & 0.76 \\
\hline Surface area, $\mathrm{cm}^{2} / \mathrm{g}$ & 18.4 & 17.6 & 22.6 & 20.7 & 0.41 & $<0.01$ & 0.01 & 0.20 \\
\hline
\end{tabular}

${ }^{1}$ Percentage of particles retained on each sieve (DM basis).

${ }^{2}$ Proportion of kernels smaller than $4.75-\mathrm{mm}$.

\subsection{DISCUSSION}

The nutrient composition of whole-plant corn on average (\% DM) was $33.2 \%$ starch and $44.1 \%$ NDF which idicates high nutrional quality based on international standards (Owens, 2014). Recently, in a review of literature, Ferraretto et al. (2018) observed a decrease of particles larger than 18 or $19-\mathrm{mm}$ by $20 \%$ for processed WPCS. Andrae et al. (2001) noted that kernel processing led to drop of large particles (>19-mm) followed by an increase in midsize (8 to $19-\mathrm{mm})$ and small $(<8-\mathrm{mm})$ particles for WPCS harvested by SPFH at $19-\mathrm{mm}$ of TLOC. Jonhson et al (2002) reported, in experiment 1, a decrease of particles on the top PSPS layer which, in turn, increased particle retained in the 8-mm and MPL for processed WPCS harvested at 6.4-mm of TLOC. Similar effects of KP were noticed in the present study, but these occurred only for TLOC of 10-mm. It is not clear the lack of impact for the short TLOC (6-mm) in the current trial. At equal TLOC settings, a reduction in particle size by about 15 to $30 \%$ due to kernel processor has been observed (Schurig and Rodel, 1993; Roberge et al., 1998). The processing rolls crush and shear the stover fraction (Johnson et al., 2003) and, as a 
consequence, eliminates intact cobs and long particles especially under tight roll gap setting (Shinners et al., 2000).

The fine adjustment from 10 to 6-mm of TLOC reduced particles larger than 19-mm and tended to increase particles in the bottom pan as well as reducing the MPL. Shinners et al. (2000) reported a decrease of $23.8 \%$-units of particles retained above the 18 -mm sieve, as a result, a drop in MPL from 13 to 11.0 -mm occured for WPCS harvested at 2 TLOC settings (25.4 and 12.7) in PTFH with a KP. In this trial the particle size was determined by an apparatus and procedure described in American Society of Agricultural Engineers - ASAE standard S424.1 (ASAE, 1998). Ferraretto et al. (2015) evaluated the impact of 2 TLOC settings (6.4-mm or 19.5-mm), 3 hybrids and at 2 maturities in WPCS particle size. Particle size reduced with lowest TLOC as expected. The samples harvested at 6.4-mm TLOC, on average, had less material retained in the coarse (3.5 vs. 9.0\%), however the material in the bottom pan did not differ between TLOC settings. Besides TLOC and kernel processing, others factors can influence the MPL in WPCS, such as processor roll-gap setting (Shinners et al., 2000), silage ensiling time (Johnson et al., 2003), DM content (Shinners et al., 2000), ratio of kernel to stover (Mertens, 2005), hybrid (Johnson et al., 2002), knife sharpness and knifeto-shear bar clearance (Shinners, 2003).

Shinners et al. (2000) reported a drop in kernel GMPS and, as a consequence, an increase of surface area for processed WPCS. In the current trial was observed similar response; apparently, there was a reduction of kernels retained in 6.7 and 4.75-mm sieves followed by a rise in the percentage of kernels retained at bottom sieves. Dias Junior et al. (2016) cut manually unfermented kernels from 110 hybrids in 4 and 8 pieces and sifted in RoTap shaker with the same set of sieves used in our trial. The percentages of kernels smaller than $4.75-\mathrm{mm}$ were 38.9 and $94.4 \%$, respectively. Based on these observations, it suggests that the most part of kernel particles were broken at least in 4 pieces in our trial. There is a recommendation which corn particles should have greater than 65 to $70 \%$ of kernels broken into pieces less than one-third to one-fourth of a kernel in size (Kung and Muck, 2017). In this way, the WPCS harvested by PTK probably achieved this target more effectively. The processed WPCS had higher concentration of starch in the material below 8-mm sieve. Weiss and Wyatt (2000) also reported a rise of starch content in this fraction for processed WPCS harvested at 19-mm of TLOC in comparison with unprocessed at 10-mm TLOC. The reduction of TLOC improved GMPS and surface area. Shinners et al. (2000) noted an increase of broken kernels by $8.5 \%$ units of total kernel mass when TLOC was reduced from 19 to $9.5-\mathrm{mm}$ in unprocessed WPCS. However, the kernel GMPS and surface area were not 
affected by TLOC in this trial. Johnson et al. (1999) also supposed a possible improvement of kernel breakage by harvester cutting knives when TLOC is reduced.

\subsection{CONCLUSIONS}

The new PTFH with KP promoted a greater kernel breakage. The impact of this harvester in WPCS particle size distribution was pronounced in the TLOC of 10-mm which led to drop in MPL. The reduction of TLOC for both forage harvesters may be a good strategy to fracture corn kernels for WPCS at $34.8 \%$ of DM. There is a lack of information regarding kernel processors and the right TLOC settings for PTFH in distinct field scenarios (maturity and hybrids) and further research is warranted.

\section{LITERATURE CITED}

Andrae, J. G., C. W. Hunt, G. T. Pritchard, L. R. Kennington, J. H. Harrison, W. Kezar, and W. Mahanna. 2001. Effect of hybrid, maturity, and mechanical processing of corn silage on intake and digestibility by beef cattle. J. Anim. Sci. 79:2268-2275.

AOAC International. 2012. Official Methods of Analysis. 19th ed. AOAC International, Arlington, VA.

ASAE Standards, $44^{\text {th }}$ Ed. 1998. S424.1. Method of determining and expressing particle size of chopped forage materials by screening. St. Joseph, Mich.: ASAE.

Baker, S., and T. Herrman. 2002. Evaluating particle size. MF-2051. Kansas State Univ., Manhattan.

Bernardes, T. F., and A. C. Rego. 2014. Study on the practices of silage production and utilization on Brazilian dairy farms. J. Dairy Sci. 97:1852-1861.

Bernardes, T. F., J. L. P. Daniel, A. T. Adesogan, T. A. McAllister, P. Drouin, L. G. Nussio, P. Huhtanen, G. F. Tremblay, G. Bélanger, and Y. Cai. 2018. Silage review: Unique challenges of silages made in hot and cold regions. J. Dairy Sci. 101:4001-4019.

Correa, C. E. S., R. D. Shaver, M. N. Pereira, J. G. Lauer, and K. Kohn. 2002. Relationship between corn vitreousness and ruminal in situ starch degradability. J. Dairy Sci. 85:30083012 .

Daniel, J. L. P., Bernardes, T. F., C. C. Jobim, P. Schmidt, and L. G. Nussio.Production and utilization of silages in tropical areas with focus in Brazil. 2019. Grass Forage Sci. 1-13.

Dombrink-Kurtzman, M. A., and J. A. Bietz. 1993. Zein composition in hard and soft endosperm of maize. Cereal Chem. 70:105-108. 
Dias Junior, G. S., L. F. Ferraretto, G. G. S. Salvati, L. C. de Resende, P. C. Hoffman, M. N. Pereira, and R. D. Shaver. 2016. Relationship between processing score and kernelfraction particle size in whole-plant corn silage. J. Dairy Sci. 99:2719-2729.

Ferraretto, L. F., and R. D. Shaver. 2012. Meta-analysis: Impact of corn silage harvest practice on intake, digestion and milk production by dairy cows. Prof. Anim. Sci. 28:141149.

Ferraretto, L. F., P. M. Crump, and R. D. Shaver. 2015. Effect of ensiling time and exogenous protease addition to whole-plant corn silage of various hybrids, maturities and chop lengths on nitrogen fractions and ruminal in vitro starch digestibility. J. Dairy Sci. 98:8869-8881.

Ferraretto, L. F., R. D. Shaver, and B. D. Luck. 2018. Silage review: Recent advances and future technologies for whole-plant and fractionated corn silage harvesting. J. Dairy Sci. 101:3937-3951.

Hall, M. B. 2015. Determination of dietary starch in animal feeds and pet food by an enzymatic-colorimetric method. Collaborative study. J. AOAC Int. 98:397-409.

Heinrichs, A. J. 2013. The Penn State Particle Separator.Extension publication DSE 2013186.Pennsylvania State University, College Park.

Johnson, L., J. H. Harrison, C. Hunt, K. Shinners, C. G. Doggett, and D. Sapienza. 1999. Nutritive value of corn silage as affected by maturity and mechanical processing: A contemporary review. J. Dairy Sci. 82:2813-2825.

Johnson, L. M., J. H. Harrison, D. Davidson, W. C. Mahanna, and K. Shinners. 2003. Corn silage management: Effects of hybrid, chop length, and mechanical processing on digestion and energy content. J. Dairy Sci. 86:208-231.

Johnson, L. M., J. H. Harrison, D. Davidson, J. L. Robutti, M. Swift, W. C. Mahanna, and K. Shinners. 2002. Corn silage management I: Effects of hybrid, maturity, and mechanical processing on chemical and physical characteristics. J. Dairy Sci. 85:833-853.

Kung Jr., L., and R. E. Muck.Silage harvesting and storage. 2017. Pages 723-738 in Large Dairy Herd Management ( $3^{\circ}$ ed.) edited by D. K. Beede. 1376 p.

Mertens, D. R. 2005. Particle size, fragmentation index, and effective fiber: Tools for evaluating the physical attributes of corn silages. Pages 211-220 in Proc. Four-State Dairy Nutr. Mgmt. Conf., Dubuque, IA.

Nigon, B. J., K. J. Shinners, and D. E. Cook. 2016. Harvester modifications to alter composition and dry matter of corn-silage. Appl. Eng. Agric. 32:157-167. 
Owens, F. 2014. New technologies in forage varieties and production. Pages 103-121 in Proc. Tri-State Dairy Nutr.Conf., Ft. Wayne, IN. Ohio State Univ., Columbus.

Roberge, M., P. Savoie, and E. R. Norris. 1998. Evaluation of a crop processor in a pull-type forage harvester. Trans. ASAE 41:967-972.

Wiles, P. G., I. K. Gray, and R. C. Kissling. 1998. Routine analyses of protein by Kjeldahl and Dumas methods: Review and inter-laboratory study using dairy products. J. AOAC Int. 81:620-632.

Wilkinson, J. M., and Rinne, M. 2018. Review: Highlights of progress in silage conservation and future perspectives. Grass and Forage Science 73:40-52.

Schurig, M., and G. Rodel. 1993. Power consumption and the effects of corn crackers. ASAE Paper 93-1586. American Society of Agricultural Engineers, St. Joseph, MI.

Shinners, K. J. 2003.Engineering principles of silage harvesting equipment. Pages 361-403 in Silage Science and Technology. D. R. Buxton, R. E. Muck, and H. J. Harrison, ed. ASA, CSA, and SSSA, Madison, WI.

Shinners, K. J., A. G. Jirovec, R. D. Shaver, and M. A. Bal. 2000. Processing whole-plant corn silage with crop processing rolls on a pull-type forage harvester. Appl. Eng. Agric. $16: 323-331$.

Weiss, W. P., and D. J. Wyatt. 2000. Effect of oil content and kernel processing of corn silage on digestibility and milk production by dairy cows. J. Dairy Sci. 83:351-358. 


\title{
4. IMPACT OF KERNEL PROCESSING AND PARTICLE SIZE IN WHOLE PLANT CORN SILAGE WITH VITREOUS ENDOSPERM ON DAIRY COW PERFORMANCE
}

\begin{abstract}
Whole-plant corn silage (WPCS) is a major source of forage for lactating dairy cattle in Brazil. Improved kernel processing may be especially advantageous when feeding corn hybrids with vitreous endosperm, which are more difficult to be broken. The objectives of this study were: 1) to evaluate the effect of kernel processing on a Brazilian vitreous endosperm corn hybrid and 2) the increment of particle size in WPCS on intake, lactation performance, total-tract nutrient digestibility, feeding behavior and milk fatty acids profile. The following treatments were performed during the harvest: 1) pull-type forage harvester (without kernel processor, JF AT 1600) set for a 6-mm theoretical length of cut (TLOC) - PT6; 2) self-propelled forage harvester (New Holland, FR 9050) set for a 6-mm TLOC - SP6; 3) self-propelled forage harvester set for a 12-mm TLOC SP12; and 4) self-propelled forage harvester set for a 18-mm TLOC - SP18. Corn silage processing scores of the WPCS were: $32.1 \%$ (PT6), $53.9 \%$ (SP6), $49.0 \%$ (SP12) and 40.1\% (SP18). Holstein cows $(\mathrm{n}=24 ; 139 \pm 63$ DIM) were blocked and assigned to six $4 \times 4$ Latin squares, with $24-\mathrm{d}$ period (18 $\mathrm{d}$ of adaptation). Diets were formulated to contain (\% DM) $48.5 \%$ WPCS, $9.5 \%$ soybean meal, $6.9 \%$ soybean meal non-enzymatic browned, $15.1 \%$ dry ground corn, $15.5 \%$ citrus pulp, $1.7 \%$ minerals and vitamins mix, $1.8 \%$ calcium soap of palm fatty acids, and $1 \%$ urea. Nutrient composition of the diets (\% DM) was: $16.5 \% \mathrm{CP}$, $28.9 \%$ NDF and $25.4 \%$ starch. Three orthogonal contrasts were used to compare treatments: $\mathrm{C}_{1}=$ PT6 vs. SP6 (effect of kernel processing), $\mathrm{C}_{2}=$ SP6 vs. SP12 (effect of particle size) and $\mathrm{C}_{3}=$ SP12 vs. SP18 (effect of particle size). Cows fed SP6 WPCS had greater $1.2 \mathrm{~kg} / \mathrm{d}$ milk yield with no changes in DMI, resulting in greater feed efficiency when compared with PT6. The total-tract starch digestibility (TTSD) and plasma glucose was also improved when cows were fed SP6. Moreover, the higher milk protein $(+36 \mathrm{~g} / \mathrm{d})$, lactose $(+61 \mathrm{~g} / \mathrm{d})$ and solids $(+$ $94 \mathrm{~g} / \mathrm{d}$ ) secretions were a result of the improvement in milk yield for SP6 cows. In addition, the mechanism apparently involved a better nutrient digestibility and glucose availability for the synthesis of lactose by the mammary gland. There was no evidence for differences in DMI $(\mathrm{kg} / \mathrm{d})$ among self-propelled treatments. The SP12 achieved the same milk yield of SP6; however the SP12 cows tended to reduce plasma D-lactate and serum amiloyd A (SAA) while maximizing chewing time and sorting for fine particles. In SP6, cows selected against fine particles and tended to show higher levels of SAA than PT6. The SP18 reduced TTSD and tended to reduce milk production, and plasma glucose. The SP6 raised milk linear-odd chain fatty acids content in comparison with PT6. Nonetheless, a reduction of these same fatty acids occurred in SP12 in relation to SP6. SP6 cows had higher content of some monounsaturated fatty acids (C14:1and C16:1), however the opposite occurred for SP12. Kernel processing at TLOC settings of 6 and 12-mm enhanced TTSD, plasma glucose and milk yield, whereas the $18-\mathrm{mm}$ TLOC impaired lactation performance. The TLOC of 12-mm improved chewing
\end{abstract}


time and reduced blood sub-acute acidotic markers. Thereby, it appeared to be the best setting to harvest WPCS from vitreous endosperm corn hybrid.

Keywords: Kernel processing; Vitreous endosperm; Starch digestibility; Plasma glucose

\subsection{INTRODUCTION}

Whole-plant corn silage (WPCS) is a major source of forage for lactating dairy cattle in Brazil (Bernardes and Rêgo, 2014), in the United States (Martin et al., 2017, Ferraretto et al., 2018), and world-wide (Ferraretto et al., 2018). The high adoption of WPCS is justified by relatively high yield of low-cost starch per hectare (Wilkinson and Rinne, 2018), lower harvesting costs, minimized risks of production, flexibility to harvest corn for forage or kernel (Allen et al., 2003), rapid harvest, and ease of ensiling (Nigon et al., 2016). Furthermore, WPCS provides high energy (mainly from starch in the kernel fraction) and physically effective NDF (peNDF; derived from the stover fraction, Ferraretto et al., 2018).

Approximately $72 \%$ of the kernel fraction is composed by starch (DM basis; Huntington, 1997) that represents nearly $45 \%$ of the whole-plant DM (Philippeau and Michalet-Doreau, 1998) and about half of the energy in WPCS (calculated using NRC, 2001). The digestibility of the starch component of WPCS is influenced primarily by kernel processing, maturity (Ferraretto and Shaver, 2012) and length of storage (Der Bedrosian et al., 2012). There is a high variability in total-tract starch digestibility (TTSD, from 80 to $98 \%$ ) of WPCS in lactating dairy cows fed WPCS-based diets (Ferraretto and Shaver, 2012). The interest in improving starch digestibility in WPCS by lactating dairy cows has been stimulated due to the relative high cost of corn kernels in the market.

In relation to increased feeding levels of WPCS in dairy cow diets, there has been interest setting the forage harvester for a longer theoretical length of cut (TLOC) with the aim of increasing the mean particle length (MPL) of WPCS. To harvest WPCS, greater TLOC settings $(\geq 19 \mathrm{~mm})$ are used on customized forage harvesters that are equipped with kernelprocessing rolls in an attempt to maintain or improve fiber effectiveness as the stover is also crushed by the rolls (Johnson et al., 2003). Increasing the TLOC of forages might be a strategy to increase the peNDF of diets (Mertens, 1997) which may improve rumination activity, salivary buffering and rumen mat formation in dairy cows (Mertens, 1997; Zebeli et al., 2012). However, the concerns of this practice is feed bunk sorting in high TLOC forages 
(Vanderwerrff et al., 2015) that can make dairy cows prone to subacute ruminal acidosis (SARA).

In Brazil, most dairy farmers harvest the corn crop with a pull-type forage harvester (PTFH; Bernardes and Rego, 2014). Brazilian PTFH do not have specialized kernel processor displays (Bernardes et al., 2018) and the most cultivated hybrids have flint kernel with a higher proportion of vitreous endosperm (Correa et al., 2002; Bernardes et al., 2018) which is more difficult to damage during harvesting (Ferraretto et al. 2018); thereby compromising kernel processing. In the United States, the typical range of TLOC to chop corn plants for WPCS is from 19-mm to 26-mm (Grant and Ferraretto, 2018). However, the hypothesis of our study was that to achieve adequate kernel processing in vitreous endosperm hybrid a lower TLOC would be required. Therefore, the objectives of this study were: 1) to evaluate the effect of kernel processing on a Brazilian vitreous endosperm corn hybrid and 2) the increment of particle size in WPCS on intake, lactation performance, total-tract nutrient digestibility, feeding behavior and milk fatty acids profile.

\subsection{MATERIALS AND METHODS}

Fifteen hectares of a vitreous corn hybrid (DKB 177 VT PRO 2, Dekalb, Monsanto, Dekalb, Illinois, USA) were planted on November 4, 2015, at a density of 68,750 seeds per hectare at the Luiz de Queiroz College of Agriculture - University of São Paulo (Piracicaba, São Paulo, Brazil). The harvesting occurred on February 17, 2016, at approximately one-half of milk line stage of kernel maturity and at 34\% DM of whole-plant. The field was harvested in alternating strips in an attempt to keep similar nutrient compositions among treatments. Treatments were performed during the harvesting process. A PTFH (JF AT 1600 PTFH; JF Máquinas Agrícolas, Itapira, Brazil) set for 6-mm of TLOC without a kernel processor was used to harvest the PT6 treatment. A self-propelled forage harvester (SPFH; FR 9050; CNH Industrial, New Holland, Pennsylvania, USA) equipped with conventional rolls set for a 1$\mathrm{mm}$ roll gap and a $22 \%$ roll speed differential was used to harvest the following TLOC treatments: 6-mm (SP6), 12-mm (SP12) and 18-mm (SP18). The silages were stored in bunker silos for approximately 10 months before initiating the feeding trial.

The animal performance trial was conducted from December 4, 2016 to March 10, 2017, in anopen walled sand bedded free-stall barn with fans, and equipped with feed monitoring system (Intergado Ltda., Contagem, Minas Gerais, Brazil). The trial protocol was approved by the Luiz de Queiroz College of Agriculture - University of São Paulo Bioethic 
Committee in Utilization of Animals (Protocol $n^{0}$ 2018.5.865.11.4). Twenty-four Holstein cows (139 \pm 63 DIM) were stratified in squares of 4 cows by parity, DIM and milk yield, and within squares, were random assigned to a sequence of 4 treatments (PT6; SP6; SP12 and SP18) in a replicated $4 \times 4$ Latin-square, with $24 \mathrm{~d}$ periods and $18 \mathrm{~d}$ of adaptation. Dietary ingredient composition is provided in Table 12. Trace minerals and vitamins were supplemented to meet or exceed NRC (2001) guidelines. All cows received bST (500 mg/ head; Boostin ${ }^{\circledR}$, Intervet Schering-Plough, Cruzeiro, Brazil) every $12 \mathrm{~d}$.

Table 12. Ingredient composition of experimental diets ${ }^{1}$

\begin{tabular}{lcccc}
\hline Item & PT6 & SP6 & SP12 & SP18 \\
\hline Diet ingredient, \% of DM & & & & \\
Corn silage & 48.5 & 48.2 & 48.7 & 48.9 \\
Soybean meal & 9.5 & 9.5 & 9.4 & 9.4 \\
Soybean meal non-enzymatic browned ${ }^{2}$ & 6.9 & 6.9 & 6.8 & 6.8 \\
Urea & 1.0 & 1.0 & 1.0 & 1.0 \\
Corn kernel, finely ground & 15.1 & 15.2 & 15.0 & 15.0 \\
Citrus pulp & 15.5 & 15.6 & 15.5 & 15.4 \\
Calcium soaps of fatty acids & 1.9 & 1.9 & 1.8 & 1.8 \\
Mineral and vitamin mix $^{3}$ & 1.7 & 1.7 & 1.7 & 1.7 \\
Coated methionine $^{4}$ & 0.05 & 0.05 & 0.05 & 0.05 \\
Live yeast $^{5}$ & 0.05 & 0.05 & 0.05 & 0.05 \\
\hline
\end{tabular}

${ }^{1}$ Treatments were PT6 = pull-type forage harvester at theoretical length of cut (TLOC) of 6-mm without kernel processor, SP6 = self-propelled forage harvester at TLOC of 6-mm, SP12 = self-propelled forage harvester at TLOC of $12-\mathrm{mm}$ or SP18 = self-propelled forage harvester at TLOC of $18-\mathrm{mm}$.

${ }^{2}$ SoyPass $^{\circledR}$ (Borregaard LignoTech, Fernandina Beach, FL, USA).

${ }^{3} 20.0 \%$ Ca; $15.6 \%$ P; $3.5 \%$ S; $3.0 \%$ Mg; $150 \mathrm{mg} / \mathrm{kg} \mathrm{Co} ; 2,000 \mathrm{mg} / \mathrm{kg} \mathrm{Cu} ; 200 \mathrm{mg} / \mathrm{kg} \mathrm{I} ; 5,000 \mathrm{mg} / \mathrm{kg} \mathrm{Mn}$; $11,900 \mathrm{mg} / \mathrm{kg} \mathrm{Zn;} 82$ mg/kg Se; 100,000 UI/kg Vitamin A; 220,000 UI/kg Vitamin D3; 6,200 UI/kg Vitamin E.

${ }^{4}$ Smartamine-M (Adisseo, Alpharetta, GA, USA).

${ }^{5}$ Procreatin-7 (Saccharomyces cerevisiae, strain NCYC 996, Lesaffre Feed Additives, Toluca, Mexico).

The experimental diets were mixed and offered twice daily at approximately 0600 and $1600 \mathrm{~h}$. Individual cow intake was assessed throughout the trial by a feed monitoring system (Intergado Ltda., Contagem, Minas Gerais, Brazil) validated by Chizzotti et al. (2015). Ingredient samples were collected daily during sampling week (last week of each period) and composite samples were prepared for each experimental period. Likewise, ort samples were collected daily and composited per cow per period. Composite samples were dried in a forced-air oven at $55^{\circ} \mathrm{C}$ for $72 \mathrm{~h}$ and ground to pass through a 1-mm screen in a Willey mill (A. H. Thomas Scientific, Philadelphia, PA). The DM, OM (method 942.05) and ether extract (method 2003.05) were determined as described by AOAC International (2012). Concentration of $\mathrm{CP}$ was determined as $\mathrm{N}$ x 6.25 after analysis with a $\mathrm{N}$ analyzer (Leco FP- 
2000; Leco Corp., St. Joseph, MI, USA) by the Dumas method (Wiles et al., 1998).The NDF was analyzed using a TE-149 fiber analyzer (TECNAL Equipamentos para Laboratórios, Piracicaba, Brazil) with heat-stable $\alpha$-amylase and sodium sulfite (method 2002.04, AOAC, 2012). Starch was analyzed according to Hall et al. (2015). The non-fibrous carbohydrate fraction was calculated as: $\mathrm{NFC}=100-(\mathrm{CP}+\mathrm{EE}+\mathrm{ash}+\mathrm{NDF})$. Neutral detergent solubles was computed as NDS $=100-$ ash - NDF. Indigestible NDF (iNDF) was measured by ruminal in situ incubation for $288 \mathrm{~h}$ (Huhtanen et al., 1994). The particle size distribution of TMR and WPCS was determined on undried and unground samples using the Penn State Particle Separator (PSPS) as described by Kononnoff et al. (2003a). The physically effective NDF above the 8-mm PSPS sieve $\left(\mathbf{p e N D F}_{>\mathbf{8}}\right)$ or above $1.18-\mathrm{mm}$ PSPS sieve (peNDF $>\mathbf{1 . 1 8}$ ) was calculated as proposed by Lammers et al. (1996) and Kononoff et al. (2003b), respectively (proportion of dry matter above 1.18 or $8-\mathrm{mm}$ sieve multiplied by $\%$ of NDF). The chemical and physical characteristics of consumed diets are reported in Table 13. 
Table 13. Nutrient composition and particle size of experimental diets (mean \pm SD) ${ }^{1}$

\begin{tabular}{|c|c|c|c|c|}
\hline Item & PT6 & SP6 & SP12 & SP18 \\
\hline Dry matter, $\%$ of as fed & $50.5 \pm 0.8$ & $50.2 \pm 1.2$ & $51.9 \pm 0.6$ & $50.7 \pm 1.3$ \\
\hline \multicolumn{5}{|c|}{ Nutrient composition of diet, \% of DM } \\
\hline Crude protein & $16.7 \pm 0.3$ & $16.5 \pm 0.1$ & $16.2 \pm 0.1$ & $16.3 \pm 0.1$ \\
\hline $\mathrm{NDF}$ & $29.4 \pm 1.0$ & $28.9 \pm 0.5$ & $28.7 \pm 0.4$ & $28.7 \pm 0.8$ \\
\hline $\mathrm{iNDF}^{2}$ & $9.8 \pm 1.9$ & $8.8 \pm 1.0$ & $8.7 \pm 1.5$ & $9.5 \pm 0.8$ \\
\hline $\mathrm{peNDF}_{>8}{ }^{3}$ & $15.8 \pm 0.7$ & $14.4 \pm 1.1$ & $15.4 \pm 0.6$ & $16.1 \pm 0.4$ \\
\hline peNDF $_{>1.18}{ }^{4}$ & $23.7 \pm 0.6$ & $22.7 \pm 0.8$ & $22.6 \pm 0.7$ & $22.8 \pm 0.3$ \\
\hline Ether extract & $4.3 \pm 0.2$ & $4.3 \pm 0.1$ & $4.3 \pm 0.1$ & $4.4 \pm 0.2$ \\
\hline Ash & $5.4 \pm 0.1$ & $5.3 \pm 0.4$ & $5.1 \pm 0.2$ & $5.4 \pm 0.3$ \\
\hline Non & $43.6 \pm 1.0$ & $44.2 \pm 0.2$ & $44.7 \pm 0.6$ & $44.3 \pm 0.8$ \\
\hline Starch & $25.4 \pm 0.3$ & $25.3 \pm 0.2$ & $25.5 \pm 0.5$ & $25.5 \pm 0.2$ \\
\hline \multicolumn{5}{|l|}{ PSPS $^{5}, \%$ as fed retained } \\
\hline $19-\mathrm{mm}$ & $5.3 \pm 1.4$ & $2.7 \pm 0.8$ & $6.7 \pm 2.7$ & $15.5 \pm 6.5$ \\
\hline $8-n$ & $50 \pm 3.2$ & $47.9 \pm 6.2$ & $48.8 \pm 3.5$ & $41.5 \pm 5.3$ \\
\hline $1.18-\mathrm{mm}$ & $26.6 \pm 2.9$ & $29.0 \pm 4.7$ & $24.6 \pm 2.9$ & $23.8 \pm 4.8$ \\
\hline Bottom pan & $18.1 \pm 4.0$ & $20.4 \pm 3.3$ & $19.9 \pm 2.9$ & $19.2 \pm 4.1$ \\
\hline Mean 1 & $5.8 \pm 0.6$ & $5.2 \pm 0.6$ & $5.7 \pm 0.7$ & $6.4 \pm 1.2$ \\
\hline $\mathrm{Sgm}^{6}$ & $2.9 \pm 0.06$ & $2.9 \pm 0.01$ & $3.1 \pm 0.01$ & $3.3 \pm 0.02$ \\
\hline pef $_{>8}{ }^{7}$ & $55.3 \pm 3.8$ & $50.6 \pm 6.4$ & $55.5 \pm 5.2$ & $57.0 \pm 6.8$ \\
\hline pef $_{>1.18^{8}}$ & $81.9 \pm 4.0$ & $79.6 \pm 3.3$ & $80.1 \pm 2.9$ & $80.8 \pm 4.1$ \\
\hline \multicolumn{5}{|l|}{ peNDF of offered diet, $\%$ of } \\
\hline $\operatorname{peNDF}_{>8}$ & $16.9 \pm 0.4$ & $15.6 \pm 1.2$ & $16.9 \pm 0.6$ & $17.3 \pm 0.6$ \\
\hline $\mathrm{peNDF}_{>1.18}$ & $24.9 \pm 0.4$ & $24.2 \pm 0.8$ & $24.2 \pm 0.7$ & $24.3 \pm 0.5$ \\
\hline \multicolumn{5}{|c|}{$\begin{array}{l}{ }_{1}^{1} \text { Treatments were PT6 = pull-type forage harvester at theoretical length of cut (TLOC) of 6-mm without } \\
\text { kernel processor, SP6 = self-propelled forage harvester at TLOC of } 6 \text {-mm, SP12 = self-propelled forage } \\
\text { harvester at TLOC of } 12 \text {-mm or SP18 = self-propelled forage harvester at TLOC of 18-mm. } \\
{ }^{2} \text { Indigestible NDF determined by } 288 \mathrm{~h} \text { of in situ incubation as described by Huhtanen et al. (1994). } \\
\text { 39hysically effective NDF above the } 8 \text {-mm PSPS sieve calculated as proposed by Lammers et al. (1996). } \\
{ }^{4} \text { Physically effective NDF above the } 1.18 \text {-mm PSPS sieve calculated as proposed by Kononoff et al. (2003). } \\
{ }^{5} \text { Particle size distribution was measured using the Penn State particle size separator as described by } \\
\text { Kononnoff et al. (2003). } \\
6 \text { Geometric standard deviation calculated as described by Kononoff et al. (2003). } \\
{ }^{7} \text { Physically effective factor calculated as described by Lammers et al. (1996). } \\
{ }^{8} \text { Physically effective factor calculated as described by Kononoff et al. (2003). }\end{array}$} \\
\hline
\end{tabular}

Corn vitreousness was determined by manual dissection of the kernels (DombrinkKurtzman and Bietz, 1993) and followed the procedure described by Correa et al. (2002). Using dried and unground WPCS samples, the corn silage processing score (CSPS) was determined as described by Ferreira and Mertens (2005). Kernel particle size distribution was determined as described by Dias Junior et al. (2016). Briefly, a sub-sample of WPCS (400 g DM) was taken and had the kernel and stover fractions separated by a hydrodynamic separation procedure (Savoie et al., 2004). After separation, the kernel-fraction was transferred to disposable aluminium foil plates, re-dried at $60^{\circ} \mathrm{C}$ for $48 \mathrm{~h}$ in a forced-air oven and dry-sieved using a Tyler Ro-Tap Shaker (model RX-29, Tyler, Mentor, OH, USA) with a 
set of 9 sieves with nominal square apertures of 9.50, 6.70, 4.75, 3.35, 2.36, 1.70, 1.18, and $0.59-\mathrm{mm}$, in addition to the bottom pan. Geometric mean particle size (GMPS; $\mu \mathrm{m})$ and surface area $\left(\mathrm{cm}^{2} / \mathrm{g}\right)$ were calculated using a log normal distribution (Baker and Herrman, 2002). The percentage of kernels below the 4.75-mm screen was determined as described by Dias Junior et al. (2016).

During silage feed out, samples were collected daily and kept frozen at $-20^{\circ} \mathrm{C}$ to form a composite sample per silo. Aqueous extracts were prepared from the composite sample $(25 \mathrm{~g}+225 \mathrm{~g}$ of deionized water) and homogenized for $4 \mathrm{~min}$ in a stomacher. The extract was filtered through 3 folder cheese-cloth and centrifuged for $15 \mathrm{~min}$ at $10,000 \times \mathrm{g}$. The supernatant was analyzed for fermentation end products. Lactic acid (Pryce, 1969) and ammonia (Weatherburn, 1967) were determined by colorimetric methods and volatile fatty acids, alcohols and esters were analyzed using a gas chromatograph with a mass detector (GCMS QP 2010 plus, Shimadzu, Kyoto, Japan), using a capillary column (Stabilwax, Restek, Bellefonte, PA; 60 m, 0.25-mm, i.d., $0.2590 \mathrm{~m}$ ). The dry matter content corrected for volatiles (DMcorr) was calculated using the equation of Weissbach (2009): DMcorr (\% as fed $)=$ oven DM $(\%$ as fed $)+n$-alcohols $(\%$ as fed $)+2,3$-butanediol $(\%$ as fed $)+0.95 \times$ volatile fatty acids $(\%$ as fed $)+0.77 \times 1,2$-propanediol $(\%$ as fed $)+0.08 \times$ lactic acid $(\%$ as fed). The chemical composition, fermentation profile, and physical characteristics of wholeplant corn silage are in Table 14. 
Table 14. Chemical composition, fermentation, and physical characteristics of wholeplant corn silage ${ }^{1}$

\begin{tabular}{|c|c|c|c|c|}
\hline Item & PT6 & SP6 & SP12 & SP18 \\
\hline \multicolumn{5}{|l|}{ Nutrient } \\
\hline DM, $\%$ as fed & $33.4 \pm 1.2$ & $33.4 \pm 0.6$ & $34.1 \pm 0.7$ & $33.2 \pm 1.0$ \\
\hline DMcorr, $\%$ as fed ${ }^{2}$ & $33.7 \pm 1.6$ & $33.7 \pm 1.1$ & $34.9 \pm 0.3$ & $33.6 \pm 1.1$ \\
\hline OM, $\%$ as fed & $95.8 \pm 0.1$ & $95.6 \pm 0.4$ & $96.0 \pm 0.1$ & $95.9 \pm 0.2$ \\
\hline $\mathrm{CP}, \%$ as fed & $5.2 \pm 0.6$ & $5.7 \pm 0.7$ & $5.5 \pm 0.7$ & $5.3 \pm 0.4$ \\
\hline Ether extract, \% of DM & $3.2 \pm 0.3$ & $3.5 \pm 0.1$ & $3.3 \pm 0.2$ & $3.4 \pm 0.1$ \\
\hline $\mathrm{NDF}, \%$ of DM & $44.7 \pm 4.1$ & $44.8 \pm 1.8$ & $42.8 \pm 1.3$ & $43.0 \pm 1.5$ \\
\hline $\mathrm{iNDF}^{2}, \%$ of $\mathrm{DM}$ & $18.0 \pm 0.5$ & $18.5 \pm 1.3$ & $18.9 \pm 2.0$ & $18.3 \pm 1.1$ \\
\hline Starch, \% DM & $31.6 \pm 2.8$ & $31.8 \pm 3.1$ & $32.4 \pm 4.1$ & $32.5 \pm 4.3$ \\
\hline \multicolumn{5}{|l|}{ Fermentation profile } \\
\hline $\mathrm{pH}$ & $4.0 \pm 0.2$ & $3.8 \pm 0.1$ & $3.9 \pm 0.2$ & $4.0 \pm 0.1$ \\
\hline Lactic acid, $\%$ of DMcorr & $3.0 \pm 0.8$ & $3.5 \pm 1.2$ & $3.1 \pm 0.4$ & $3.0 \pm 0.8$ \\
\hline Acetic acid, \% of DMcorr & $2.3 \pm 0.6$ & $2.4 \pm 1.5$ & $2.2 \pm 0.5$ & $2.2 \pm 1.2$ \\
\hline Propionic acid, $\%$ of DMcorr & $0.45 \pm 0.19$ & $0.34 \pm 0.24$ & $0.40 \pm 0.09$ & $0.40 \pm 0.21$ \\
\hline 1,2-Propanediol, \% of DMcorr & $0.48 \pm 0.26$ & $0.43 \pm 0.06$ & $0.45 \pm 0.15$ & $0.20 \pm 0.03$ \\
\hline 2,3-Butanediol, \% of DMcorr & $0.18 \pm 0.07$ & $0.13 \pm 0.09$ & $0.16 \pm 0.03$ & $0.15 \pm 0.08$ \\
\hline 1-Propanol, \% of DMcorr & $0.08 \pm 0.02$ & $0.13 \pm 0.12$ & $0.08 \pm 0.06$ & $0.15 \pm 0.10$ \\
\hline Ethanol, $\%$ of DMcorr & $0.09 \pm 0.03$ & $0.10 \pm 0.08$ & $0.09 \pm 0.03$ & $0.11 \pm 0.06$ \\
\hline Butyric acid, $\%$ of DMcorr & $0.02 \pm 0.01$ & $0.01 \pm 0.01$ & $0.01 \pm 0.01$ & $0.02 \pm 0.02$ \\
\hline Ammonia-N, \% of CP & $5.7 \pm 0.1$ & $5.8 \pm 0.2$ & $5.1 \pm 0.5$ & $5.6 \pm 0.2$ \\
\hline \multicolumn{5}{|l|}{ CSPS, $\%$ passing $4.75-\mathrm{mm} \mathrm{sieve}^{3}$} \\
\hline Starch & $32.1 \pm 3.5$ & $53.9 \pm 4.8$ & $49.0 \pm 2.9$ & $40.1 \pm 5.5$ \\
\hline \multicolumn{5}{|l|}{ Kernel fraction } \\
\hline $\mathrm{GMPS}^{5}, \mu \mathrm{m}$ & $4585 \pm 351$ & $3422 \pm 350$ & $3762 \pm 534$ & $4017 \pm 399$ \\
\hline Surface area, $\mathrm{cm}^{2} / \mathrm{g}$ & $13.2 \pm 1.4$ & $17.6 \pm 1.7$ & $17.0 \pm 2.1$ & $16.5 \pm 1.9$ \\
\hline$\%$ kernels $<4.75-\mathrm{mm}$ sieve ${ }^{6}$ & $33.8 \pm 4.8$ & $54.2 \pm 6.4$ & $48.9 \pm 7.8$ & $41.9 \pm 5.1$ \\
\hline \multicolumn{5}{|l|}{ PSPS $^{7}, \%$ as fed retained } \\
\hline 19-mm & $9.0 \pm 4.2$ & $4.0 \pm 1.9$ & $9.8 \pm 6.5$ & $19.3 \pm 4.2$ \\
\hline $8-\mathrm{mm}$ & $76.4 \pm 2.6$ & $79.1 \pm 2.2$ & $76.6 \pm 4.4$ & $69.7 \pm 2.4$ \\
\hline $1.18-\mathrm{mm}$ & $12.3 \pm 1.7$ & $14.4 \pm 3.2$ & $10.6 \pm 1.4$ & $8.9 \pm 2.6$ \\
\hline Bottom pan & $2.4 \pm 0.5$ & $2.6 \pm 0.8$ & $3.0 \pm 0.8$ & $2.1 \pm 0.7$ \\
\hline Mean particle length, $\mathrm{mm}$ & $10.8 \pm 0.8$ & $10.0 \pm 0.8$ & $11.0 \pm 1.0$ & $12.4 \pm 0.7$ \\
\hline $\operatorname{Sgm}^{8}$ & $1.89 \pm 0.05$ & $1.85 \pm 0.09$ & $1.92 \pm 0.04$ & $1.95 \pm 0.04$ \\
\hline
\end{tabular}

${ }^{1}$ Treatments were PT6 = pull-type forage harvester at theoretical length of cut (TLOC) of 6-mm without kernel processor, SP6 = self-propelled forage harvester at TLOC of 6-mm, SP12 = self-propelled forage harvester at TLOC of 12-mm or SP18 = self-propelled forage harvester at TLOC of $18-\mathrm{mm}$.

${ }^{2}$ Dry matter content corrected for volatiles was calculated using the equation of Weissbach (2009): DMcorr $(\%$ as fed $)=$ oven DM $(\%$ as fed $)+n$-alcohols $(\%$ as fed $)+2,3$-butanediol $(\%$ as fed $)+0.95 \times$ volatile fatty acids ( $\%$ as fed) $+0.77 \times 1,2$-propanediol $(\%$ as fed $)+0.08 \times$ lactic acid $(\%$ as fed).

${ }^{3}$ Indigestible NDF determined by $288 \mathrm{~h}$ of in situ incubation as described by Huhtanen et al. (1994).

${ }^{4}$ Processing score was measured as described by Ferreira and Mertens (2005).

${ }^{5}$ Geometric mean particle size was measured as described by Dias Junior et al. (2016).

${ }^{6}$ Proportion of hydrodynamically separated kernel fraction passing through a $4.75-\mathrm{mm}$ sieve.

${ }^{7}$ Particle size was measured using the Penn State particle size separator as described by Kononoff et al. (2003).

${ }^{8}$ Geometric standard deviation calculated as described by Kononoff et al. (2003). 
Cows were milked twice daily, at 0600 and 1600 h, and milk yield was recorded daily. Milk samples were obtained on d 21 and 22 during four consecutive milkings. Milk components and milk urea nitrogen (MUN) content were measured in Clínica do Leite (Piracicaba, Brazil) by mid-infrared analysis (Bentley 2000. Bentley Instruments Inc., Chaska, MN, USA). Milk energy secretion (Mcal/d) was calculated as: $[(0.0929 \mathrm{x} \% \mathrm{fat})+(0.0547 \mathrm{x}$ $\%$ protein $)+(0.0395 \times \%$ lactose $)] \times \mathrm{kg}$ of milk (NRC, 2001). Energy corrected milk (ECM) was calculated as: Energy secretion/0.70 (Assumes $0.70 \mathrm{Mcal} / \mathrm{kg}$ for milk with $3.7 \%$ fat, $3.2 \%$ protein, and $4.6 \%$ lactose). $4 \%$ fat corrected milk (4\% FCM) was calculated as: $(0.4+$ 15 x \% fat / 100) x kg of milk (NRC, 2001). Body condition score (BCS; scale of 1 to 5; Wildman et al., 1982) was measured by three trained evaluators each experimental period and the average was used to describe the experimental units. After the morning milking, BW was also measured at each experimental period.

Milk samples collected on d 22 were used to isolate fat and determine the milk fatty acids (FA) profile. The samples were frozen and stored at $-20^{\circ} \mathrm{C}$ until the preparation for the gas chromatographic analysis, performed in the laboratory at the University of Sao Paulo (Pirassununga, Brazil). The samples were centrifuged at $17,800 \mathrm{x} \mathrm{g}$ for $30 \mathrm{~min}$ at $4^{\circ} \mathrm{C}$ and next for $19,300 \mathrm{x}$ g for $20 \mathrm{~min}$ at $4^{\circ} \mathrm{C}$, according to Feng et al. (2004). The separated fat $(0.300$ $0.400 \mathrm{~g}$ ) was methylated and the methyl esters were formed according to Kramer et al. (1997). Two internal C18:0 and C19:0 FA standards were used for correcting losses during the process of methylation. The fatty acids were quantified by chromatography gas (Shimadzu GC 2010 with automatic injection) using capillary column SP-2560 (100 m × 0.25-mm i.d. with 0.02-mm of film thickness (Supelco, Bellefonte, PA, USA). The initial temperature was $70^{\circ} \mathrm{C}$ for four minutes $\left(13^{\circ} \mathrm{C} /\right.$ minute $)$ until it reached a maximum temperature of $175^{\circ} \mathrm{C}$. This temperature was maintained for $27 \mathrm{~min}$. Afterwards, a new increase of $4^{\circ} \mathrm{C} /$ minute was initiated until $215^{\circ} \mathrm{C}$, which was maintained for $31 \mathrm{~min}$. Hydrogen was used as carrier gas with a flux of $40 \mathrm{~cm} / \mathrm{s}$. During the process of identification four standards were used: standard C4-C24 FA (Supelco ${ }^{\circledR}$ TM 37), vaccenic acid C18:1trans-11 (V038-1G, Sigma $\left.{ }^{\circledR}\right)$, CLA C18:2 trans-10, cis-12 (UC-61 M 100 MG), and CLA C18:2 cis-9, trans-11 (UC-60 M 100 MG; NU-CHEK-PREP USA ${ }^{\circledR}$ ) for identification of fatty acids that are formed during the biohydrogenation. The daily secretion of fatty acids in milk was calculated considering that the daily production of fat is comprised of $93.3 \%$ fatty acids and $6.7 \%$ glycerol (Jenkins, 2004).

On d 20 to d 22, fecal grab samples were collected every $8 \mathrm{~h}$ and composed by period. Total-tract apparent digestibility of DM, OM, NDF, starch and NDS was determined using indigestible NDF (iNDF) as an internal marker (Huhtanen et al., 1994). Spot urine 
samples were collected in buckets, via stimulation of peri-vaginal area, simultaneously to fecal sampling, to estimate rumen microbial synthesis based on purine derivatives excretion. A $10 \%$ sulfuric acid solution was immediately added to the urine samples (1:9) before refrigeration at $4^{\circ} \mathrm{C}$. Composite urine samples were diluted 1:5 with distilled water and frozen at $-20^{\circ} \mathrm{C}$. The creatinine and uric acid were analyzed by laboratory kits (Doles Reagentes e Equipamentos para Laboratórios Ltda, Goiânia, Brazil). Urinary creatinine concentration was used as an indicator of urine output (Chizzotti et al., 2008). Allantoin was analyzed as described by Chen and Gomes (1992).

On $\mathrm{d} 22$, the chewing activity behavior was measured by continuous observation of buccal activity in each cow at 10 min intervals for $24 \mathrm{~h}$. Buccal activities recorded were: water ingestion, eating, rumination, and idleness. Chewing time, in min per $d$, was the sum of eating and rumination time. Chewing, eating, and rumination per unit of DMI were calculated using DMI of the day of chewing evaluation. The chewing, eating, and rumination per unit $\mathrm{NDF}$, forage $\mathrm{NDF}, \mathrm{iNDF}, \mathrm{peNDF}_{>8}$, and $\mathrm{peNDF}_{>1.18}$ intakes followed the same logic. Feed sorting was also evaluated on d 22. Individual cow samples were analyzed for particle size as described by Kononoff et al. (2003). Sorting was calculated as described by Leonardi and Armentano (2003); values $<100 \%$ indicate selective refusals, $>100 \%$ indicate a preferential consumption and those equal to $100 \%$ indicate no sorting. The time of first meal was recorded on $\mathrm{d} 22$ by visual observation.

Blood samples from the coccygeal vessels were obtained on $\mathrm{d} 23$ to determine plasma urea-N (PUN), glucose, D-lactate and serum amyloid A (SAA). Samples for PUN were obtained immediately before the first daily feeding and 1, 2, 3, 6, 12 and $15 \mathrm{~h}$ after feeding. The blood, collected in vacutainer tubes containing EDTA, was immediately refrigerated, centrifuged at $1,500 \mathrm{x}$ g for $15 \mathrm{~min}$ and the plasma was frozen at $-20^{\circ} \mathrm{C}$. The PUN content was analyzed with a laboratory kit (Urea 500. Doles Reagentes para Laboratórios Ltda, Goiânia, Brazil). Plasma glucose samples were collected 6 and 12 h postfeeding in tubes containing EDTA and sodium fluoride. They were analyzed with a laboratory kit (Glicose Enzimática Líquida. Doles Reagentes para Laboratórios Ltda, Goiânia, Brazil). In addition, plasma D-lactate content 12-h post-feeding followed the same sample collecting procedure of glucose samples and was analyzed using a commercial kit (EnzymChrom ${ }^{\mathrm{TM}} \mathrm{D}$ lactate Essay - EDLC-100. BioAssay Systems, Haywart, USA). Samples for SAA analysis were collected 12-h post-feeding in tubes containing heparin. SAA content was determined using commercial ELISA kits (SEA885Bo and SEB406Bo, respectively; Cloud-Clone Corp, Katy, USA) according with Ametaj et al. (2005). 
On d 24, rumen fluid samples were collected through a flexible oro-gastric tube. Samples were collected $12 \pm 0.35 \mathrm{~h}$ after the morning feeding. Animals were randomly sampled within each block. Ruminal pH was measured immediately (DIGIMED DM20, São Paulo, Brazil). A ruminal sample was instantaneously frozen in liquid nitrogen to stop fermentation and was kept frozen at $-20^{\circ} \mathrm{C}$ until the preparation for analysis of organic acids by Agilent 7890A gas chromatograph according to Ferreira et al. (2016). The $\mathrm{NH}_{3}-\mathrm{N}$ concentration was determined with a colorimetric method described by Chaney and Marbach (1962) and adapted for a microplate reader (BioRad, Hercules, CA, USA) with a $550 \mathrm{~nm}$ absorbance filter.

\subsubsection{Statistical analysis}

Data were analyzed using the MIXED procedure of SAS (SAS Institute Inc., Cary, NC). The model included the effects of Latin square (1 to 6), period (1 to 4), treatment (PT6, SP6, SP12 and SP18) as fixed effects; cow within square (1 to 24) was a random effect. The mean square of cow, period and treatment factors was used as the error to test the treatment effects. Outcomes measured over time were analyzed as repeated measures. The covariance structure was defined based on the Akaike's information criterion among variance compounds, autoregressive of first order, compound symmetry or unstructured. Degrees of freedom were calculated using the Kenward-Roger option. Three orthogonal contrasts were used to compare treatments: 1) PT6 vs. SP6 (effect of kernel processing), 2) SP6 vs. SP12 (effect of particle size) and 3) SP12 vs. SP18 (effect of particle size). Statistical significance and trends were considered at $\mathrm{P} \leq 0.05$ and $\mathrm{P}>0.06$ to $\mathrm{P} \leq 0.10$, respectively.

\subsection{RESULTS}

Means of CP, EE, NDF and starch were 16.4, 4.3, 28.9 and $25.4 \%$ of DM. The different TLOC settings and processing at WPCS influenced the percentage of TMR particles retained above the 19-mm sieve and MPL (Table 13). The level of $\operatorname{peNDF}_{>8}(\% \mathrm{DM})$ of consumed diets were $15.8 \pm 0.7$ (PT6), $14.4 \pm 1.1$ (SP6), $15.4 \pm 0.6$ (SP12), and $16.1 \pm 0.4$ (SP18).

The kernel vitreousness was $65.6 \pm 3.7 \%$ of total endosperm at $33.5 \%$ DM WPCS (data not shown in tables or figures). The WPCS of treatments had similar DM content, 
chemical composition and fermentation profile (Table 14). The average starch and NDF content were 32.1 and $43.8 \%$, respectively. The starch from WPCS composed approximately $61.2 \%$ of total starch diet. The CSPS were $32.1 \pm 3.5 \%$ (PT6), $53.9 \pm 4.8 \%$ (SP6), $49.0 \pm$ $2.9 \%$ (SP12), and $40.1 \pm 5.5 \%$ (SP18). The percentage of WPCS particles retained above the 19-mm sieve in treatments were $9.0 \pm 4.2$ (PT6), $4.0 \pm 1.9$ (SP6), $9.8 \pm 6.5$ (SP12) and $19.3 \pm$ 4.2 (SP18, Table 14).

Cows fed SP6 WPCS had greater $1.2 \mathrm{~kg} / \mathrm{d}$ milk yield with no changes in DMI, resulting in greater feed efficiency (milk yield/DMI) when compared with PT6 (Table 15). There was no evidence for differences in DMI $(\mathrm{kg} / \mathrm{d})$ among self-propelled treatments $(P>$ 0.05 ; SP6 vs. SP12 or SP12 vs. SP18). Milk protein $(+36 \mathrm{~g} / \mathrm{d})$, lactose $(+61 \mathrm{~g} / \mathrm{d})$ and solids (+ $94 \mathrm{~g} / \mathrm{d})$ secretions were increased when cows were fed SP6 in comparison with PT6. The percentage of casein increased (77.5 vs. $76.8 \%$ milk protein) and MUN was lower (-1.1 $\mathrm{mg} / \mathrm{dL}$ ) for cows fed SP6. There was no difference in milk production between SP6 and SP12, however, a tendency for reduction $(-0.8 \mathrm{~kg})$ was observed $(P=0.10)$ when SP12 was compared with SP18. The treatment SP12 showed less milk protein $(3.31$ vs. $3.23 \% ; P=$ $0.03)$ and casein $(2.55$ vs. $2.49 \% ; P=0.04)$ content than SP6. A tendency of less lactose content (4.64 vs. $4.59 \% ; P=0.06)$, lactose secretion $(-46 \mathrm{~g} / \mathrm{d} ; P=0.07)$ and solid yield $(-84$ $\mathrm{g} / \mathrm{d} ; P=0.10$; Table 4) occurred when cows were fed SP18. No other differences were observed in the composition or production of milk solids. BCS and BW were not affected by treatments (data not shown in tables or figures). 
Table 15. Effect of corn silage processing on the performance of dairy cows ${ }^{1}$

\begin{tabular}{lcccccccc}
\hline Item & PT6 & SP6 & SP12 & SP18 & SEM & $P \mathrm{C}_{1}^{2}$ & $P \mathrm{C}_{2}$ & $P \mathrm{C}_{3}$ \\
\hline DMI, kg/d & 19.9 & 19.3 & 19.4 & 19.5 & 0.67 & 0.16 & 0.78 & 0.81 \\
Milk, kg/d & 28.2 & 29.4 & 29.4 & 28.6 & 0.33 & 0.02 & 0.93 & 0.10 \\
$4 \% \mathrm{FCM}^{3}, \mathrm{~kg} / \mathrm{d}$ & 26.0 & 26.4 & 26.6 & 26.0 & 0.36 & 0.23 & 0.77 & 0.23 \\
$\mathrm{ECM}^{4}, \mathrm{~kg} / \mathrm{d}$ & 27.6 & 28.2 & 28.1 & 27.4 & 0.34 & 0.25 & 0.99 & 0.15 \\
Fat, kg/d & 0.978 & 0.974 & 0.981 & 0.963 & 0.0536 & 0.91 & 0.84 & 0.56 \\
Fat, \% & 3.52 & 3.37 & 3.38 & 3.39 & 0.114 & 0.19 & 0.87 & 0.99 \\
Protein, kg/d & 0.920 & 0.956 & 0.938 & 0.919 & 0.0375 & 0.01 & 0.21 & 0.23 \\
Protein, \% & 3.32 & 3.31 & 3.23 & 3.28 & 0.098 & 0.81 & 0.03 & 0.20 \\
Lactose, kg/d & 1.296 & 1.357 & 1.356 & 1.310 & 0.0841 & 0.02 & 0.96 & 0.07 \\
Lactose, \% & 4.62 & 4.65 & 4.64 & 4.59 & 0.106 & 0.26 & 0.88 & 0.06 \\
Solids, kg/d & 3.193 & 3.287 & 3.274 & 3.190 & 0.1959 & 0.06 & 0.80 & 0.10 \\
Solids, \% & 11.46 & 11.33 & 11.26 & 11.26 & 0.106 & 0.26 & 0.59 & 0.94 \\
Casein, \% & 2.53 & 2.55 & 2.49 & 2.51 & 0.022 & 0.60 & 0.04 & 0.36 \\
Casein, \% protein & 76.8 & 77.5 & 77.3 & 76.7 & 0.25 & 0.05 & 0.56 & 0.12 \\
MUN, mg/dL & 11.4 & 10.3 & 10.8 & 10.2 & 0.23 & $<0.01$ & 0.22 & 0.12 \\
Milk/DMI, kg/kg & 1.42 & 1.52 & 1.49 & 1.47 & 0.061 & $<0.01$ & 0.28 & 0.43 \\
4\% FCM/DMI, kg/kg & 1.31 & 1.37 & 1.35 & 1.33 & 0.052 & 0.09 & 0.59 & 0.60 \\
ECM/DMI, kg/kg & 1.39 & 1.47 & 1.43 & 1.41 & 0.048 & 0.04 & 0.36 & 0.59 \\
\hline
\end{tabular}

${ }^{1}$ Treatments were PT6 = pull-type forage harvester at theoretical length of cut (TLOC) of 6-mm without kernel processor, $\mathrm{SP6}=$ self-propelled forage harvester at $\mathrm{TLOC}$ of $6-\mathrm{mm}, \mathrm{SP12}=$ self-propelled forage harvester at TLOC of 12-mm or SP18 = self-propelled forage harvester at TLOC of 18-mm.

${ }^{2}$ Orthogonal contrasts includes $\mathrm{C}_{1}$ - PT6 vs. SP6, $\mathrm{C}_{2}$ - SP6 vs.SP12, and $\mathrm{C}_{3}$ - SP12 vs.SP18.

${ }^{3} 4 \%$ Fat corrected milk was calculated as followed equation: $(0.4+15 \times \%$ fat $/ 100) \times \mathrm{kg}$ of milk (NRC, 2001).

${ }^{4}$ Energy corrected milk was calculated as followed equation: $\mathbf{E C M}=$ Energy secretion/0.70 (Assumes 0.70 $\mathrm{Mcal} / \mathrm{kg}$ for milk with $3.7 \%$ fat, $3.2 \%$ protein, and $4.6 \%$ lactose).

The DM and OM apparent total-tract digestibilities tended to increase for SP6 compared with PT6 (Table 16). There were gains in starch (+2.2 percentage units) and NDS digestibility (+4.7 percentage units) for SP6 in comparison with PT6. A greater TTSD was observed for SP12 compared to SP18 (95.2 vs. 93.0\%, $P=0.05)$. A rise of iNDF intake $(\mathrm{kg} / \mathrm{d}$ or \% $\mathrm{BW}$ ) was observed for PT6. The intake of individual nutrients during digestibility assay were unaffected by treatments. Treatments did not affect excretion of purine derivatives (Table 17) nor ruminal parameters (VFA, $\mathrm{pH}$, and $\mathrm{N}-\mathrm{NH}_{3}$; Table 18). 
Table 16. Effect of corn silage processing on nutrient intake and apparent digestibility ${ }^{1}$

\begin{tabular}{lcccccccc}
\hline Item & PT6 & SP6 & SP12 & SP18 & SEM & $P C_{1}^{2}$ & $P C_{2}$ & $P C_{3}$ \\
\hline Intake & & & & & & & & \\
DM, kg/d & 19.5 & 19.2 & 19.5 & 19.3 & 0.79 & 0.64 & 0.55 & 0.66 \\
DM, \% BW & 3.35 & 3.30 & 3.37 & 3.32 & 0.094 & 0.58 & 0.47 & 0.58 \\
OM, kg/d & 18.2 & 18.0 & 18.1 & 18.1 & 0.71 & 0.67 & 0.79 & 0.89 \\
NDF, kg/d & 5.7 & 5.6 & 5.6 & 5.6 & 0.26 & 0.33 & 0.72 & 0.73 \\
NDF, \% BW & 0.99 & 0.95 & 0.97 & 0.95 & 0.031 & 0.29 & 0.62 & 0.62 \\
Forage NDF, kg/d & 4.2 & 4.3 & 4.3 & 4.3 & 0.23 & 0.74 & 0.82 & 0.81 \\
Forage NDF, \% BW & 0.73 & 0.74 & 0.75 & 0.74 & 0.032 & 0.80 & 0.76 & 0.75 \\
iNDF, kg/d & 2.2 & 2.0 & 2.0 & 2.1 & 0.13 & 0.05 & 0.63 & 0.42 \\
iNDF, \% BW & 0.39 & 0.33 & 0.35 & 0.36 & 0.021 & 0.01 & 0.50 & 0.51 \\
Starch, kg/d & 5.0 & 4.9 & 5.0 & 4.9 & 0.19 & 0.47 & 0.51 & 0.74 \\
CP, kg/d & 3.2 & 3.1 & 3.1 & 3.2 & 0.01 & 0.40 & 0.65 & 0.84 \\
Ether extract, kg/d & 0.8 & 0.8 & 0.8 & 0.9 & 0.03 & 0.60 & 0.71 & 0.45 \\
Total-tract digestibility, \% & & & & & & & & \\
DMD $^{3}$ & 68.9 & 73.0 & 72.2 & 71.5 & 2.15 & 0.09 & 0.73 & 0.78 \\
OMD $^{4}$ & 71.0 & 75.3 & 74.3 & 73.8 & 2.01 & 0.07 & 0.69 & 0.81 \\
NDFD $^{5}$ & 52.1 & 55.0 & 55.2 & 55.5 & 3.63 & 0.47 & 0.95 & 0.93 \\
NDSD $^{6}$ & 79.6 & 84.3 & 82.8 & 81.9 & 1.64 & 0.01 & 0.43 & 0.62 \\
Starch-D $^{7}$ & 93.1 & 95.3 & 95.2 & 93.0 & 0.78 & 0.04 & 0.93 & 0.05 \\
\hline
\end{tabular}

${ }^{\mathrm{T}}$ Treatments were PT6 = pull-type forage harvester at theoretical length of cut (TLOC) of 6-mm without kernel processor, SP6 = self-propelled forage harvester at TLOC of $6-\mathrm{mm}, \mathrm{SP12}=$ self-propelled forage harvester at TLOC of 12-mm or SP18 = self-propelled forage harvester at TLOC of $18-\mathrm{mm}$.

${ }^{2}$ Orthogonal contrasts includes $\mathrm{C}_{1}$ - PT6 vs. SP6, $\mathrm{C}_{2}$ - SP6 vs. SP12, and $\mathrm{C}_{3}$ - SP12 vs. SP18.

${ }^{3}$ Dry matter digestibility.

${ }^{4}$ Organic matter digestibility.

${ }^{5}$ Neutral detergent fiber (NDF) digestibility.

${ }^{6}$ Neutral detergent solubles digestibility.

${ }^{7}$ Starch digestibility.

Table 17. Effect of corn silage processing on urinary purine derivatives ${ }^{1}$

\begin{tabular}{lcccccccc}
\hline & PT6 & SP6 & SP12 & SP18 & SEM & $P \mathrm{C}_{1}{ }^{2}$ & $P_{\mathrm{C}_{2}}$ & $P_{\mathrm{C}_{3}}$ \\
\hline Urine, $\mathrm{L} / \mathrm{d}$ & 27.9 & 28.9 & 32.5 & 26.6 & 3.82 & 0.83 & 0.38 & 0.19 \\
Alla, mmol/d & 226 & 219 & 224 & 208 & 15.5 & 0.69 & 0.79 & 0.37 \\
UA, mmol/d & 54 & 57 & 56 & 58 & 5.6 & 0.64 & 0.89 & 0.72 \\
Alla+UA, mmol/d & 268 & 259 & 265 & 263 & 19.6 & 0.73 & 0.81 & 0.94 \\
Alla/Crea & 1.89 & 1.79 & 1.79 & 1.64 & 0.174 & 0.52 & 0.99 & 0.38 \\
UA/Crea & 0.45 & 0.49 & 0.46 & 0.47 & 0.038 & 0.35 & 0.45 & 0.71 \\
Alla+UA/Crea & 2.35 & 2.17 & 2.26 & 2.10 & 0.173 & 0.28 & 0.61 & 0.35 \\
\hline
\end{tabular}

${ }^{1}$ Treatments were PT6 = pull-type forage harvester at theoretical length of cut (TLOC) of 6-mm without kernel processor, SP6 = self-propelled forage harvester at TLOC of $6-\mathrm{mm}, \mathrm{SP12}=$ self-propelled forage harvester at TLOC of 12-mm or SP18 = self-propelled forage harvester at TLOC of 18-mm.

${ }^{2}$ Orthogonal contrasts includes $\mathrm{C}_{1}$ - PT6 vs. SP6, $\mathrm{C}_{2}$ - SP6 vs. SP12, and $\mathrm{C}_{3}$ - SP12 vs. SP18.

${ }^{3}$ Allantoin.

${ }^{4}$ Uric acid.

${ }^{5}$ Creatinine. 
Table 18. Effect of corn processing on ruminal VFA, $\mathrm{NH}_{3}$ and $\mathrm{pH}^{1}$

\begin{tabular}{lcccccccc}
\hline Item & PT6 & SP6 & SP12 & SP18 & SEM & $P \mathrm{C}_{1}{ }^{2}$ & $P \mathrm{C}_{2}$ & $P \mathrm{C}_{3}$ \\
\hline Acetate & 65.8 & 65.2 & 65.1 & 65.6 & 0.64 & 0.47 & 0.89 & 0.58 \\
Propionate & 20.9 & 21.6 & 21.4 & 21.3 & 0.60 & 0.40 & 0.82 & 0.96 \\
Butyrate & 10.9 & 11.0 & 11.1 & 10.6 & 0.30 & 0.72 & 0.65 & 0.25 \\
i-Butyrate & 0.4 & 0.3 & 0.4 & 0.3 & 0.03 & 0.59 & 0.32 & 0.39 \\
iso-Valerate & 0.8 & 0.7 & 0.8 & 0.8 & 0.07 & 0.14 & 0.36 & 0.97 \\
Valerate & 1.3 & 1.3 & 1.3 & 1.2 & 0.07 & 0.92 & 0.66 & 0.28 \\
& & & & & & & & \\
Acetate/Propionate & 3.2 & 3.1 & 3.1 & 3.1 & 0.11 & 0.32 & 0.83 & 0.91 \\
pH & 6.36 & 6.44 & 6.34 & 6.47 & 0.079 & 0.47 & 0.39 & 0.24 \\
& & & & & & & & \\
$\mathrm{NH}_{3}, \mathrm{mg} / \mathrm{dL}$ & 5.4 & 5.0 & 5.2 & 4.8 & 0.8 & 0.67 & 0.84 & 0.53 \\
\hline
\end{tabular}

${ }^{\mathrm{I}}$ Treatments were PT6 = pull-type forage harvester at theoretical length of cut (TLOC) of 6-mm without kernel processor, SP6 = self-propelled forage harvester at TLOC of $6-\mathrm{mm}, \mathrm{SP12}=$ self-propelled forage harvester at TLOC of 12-mm or SP18 = self-propelled forage harvester at TLOC of 18-mm.

${ }^{2}$ Orthogonal contrasts includes $\mathrm{C}_{1}$ - PT6 vs. SP6, $\mathrm{C}_{2}$ - SP6 vs. SP12, and $\mathrm{C}_{3}$ - SP12 vs. SP18.

The plasma glucose increased in SP6 by $4.1 \mathrm{mg} / \mathrm{dL}$ (Figure 3) when compared to PT6. Plasma glucose levels tended to drop $(64.3$ vs. $61.9 \mathrm{mg} / \mathrm{dL} ; P=0.08)$ between treatments SP12 and SP18, respectively. The PUN was not affected by treatments (Table 21); however it varied throughout the day (Figure 4). The highest values of PUN were observed at 3-h after feeding. The plasma D-lactate tended to increase in SP6 in comparison with SP12 (1.38 vs. $1.56 \mathrm{~m} M ; P=0.10$ ). The SAA trended to be higher for SP6 in comparison with SP12 (6.0 vs. $4.1 \mu \mathrm{g} / \mathrm{mL} ; P=0.10)$. Furthermore, a similar tendency in SAA was also observed between PT6 $(3.9 \mu \mathrm{g} / \mathrm{mL})$ and SP6 $(6.0 \mu \mathrm{g} / \mathrm{mL} ; P=0.08)$.

Table 19. Effect of corn silage processing on blood plasma metabolites1

\begin{tabular}{lcccccccc}
\hline Item & PT6 & SP6 & SP12 & SP18 & SEM & $P \mathrm{C}_{1}{ }^{2}$ & $P \mathrm{C}_{2}$ & $P_{\mathrm{C}_{3}}$ \\
\hline D-lactate, $\mathrm{m}^{5}$ & 1.42 & 1.56 & 1.38 & 1.49 & 0.097 & 0.29 & 0.10 & 0.21 \\
SAA, $\mu \mathrm{g} / \mathrm{mL}^{6}$ & 3.9 & 6.0 & 4.1 & 4.3 & 1.3 & 0.08 & 0.10 & 0.85 \\
\hline
\end{tabular}

${ }^{1}$ Treatments were PT6 = pull-type forage harvester at theoretical length of cut (TLOC) of 6-mm without kernel processor, SP6 = self-propelled forage harvester at TLOC of $6-\mathrm{mm}, \mathrm{SP12}=$ self-propelled forage harvester at TLOC of 12-mm or SP18 = self-propelled forage harvester at TLOC of 18-mm.

${ }^{2}$ Orthogonal contrasts includes $\mathrm{C}_{1}$ - PT6 vs. SP6, C $\mathrm{C}_{2}$ - SP6 vs. SP12, and $\mathrm{C}_{3}$ - SP12 vs .SP18.

${ }^{3}$ Plasma glucose content $6 \mathrm{~h}$ and $12 \mathrm{~h}$ post-feeding.

${ }^{4}$ Plasma urea nitrogen content immediately before the first daily feeding and $1,2,3,6,12$ and $15 \mathrm{~h}$ postfeeding. ' ${ }^{6}$ Serum amiloyd A content $12 \mathrm{~h}$ post-feeding. 


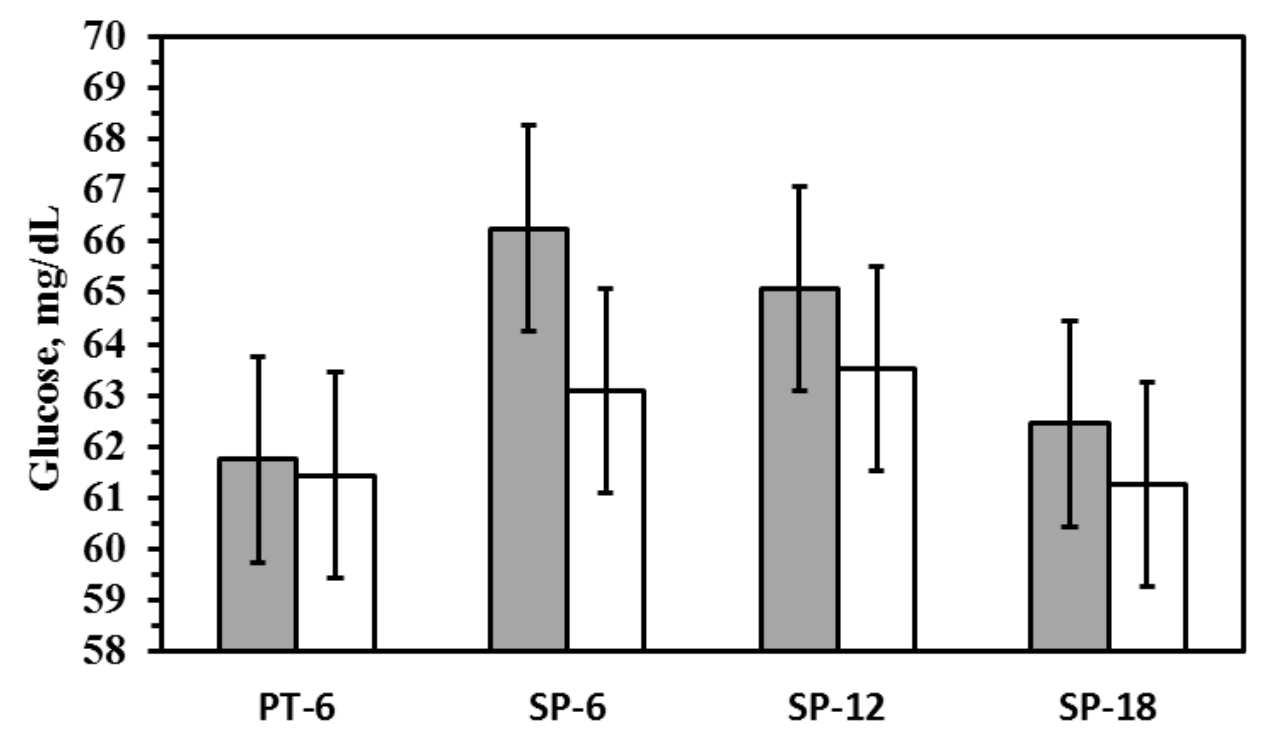

Figure 3. Plasma glucose concentration at $6 \mathrm{~h}(\square)$ or $12 \mathrm{~h}$ post-feeding ( $\square$ ) for treatments PT6, SP6, SP12 or SP18 $(P$ PT6 vs. SP6 $=0.03 ; P$ SP6 vs. SP12 $=0.80 ; P$ SP12 vs. SP18 $=0.08 ; P$ treat $=0.05 ; P$ time $=0.18 ; P$ treat $*$ time $=0.83 ; \mathrm{SEM}=2.61)$

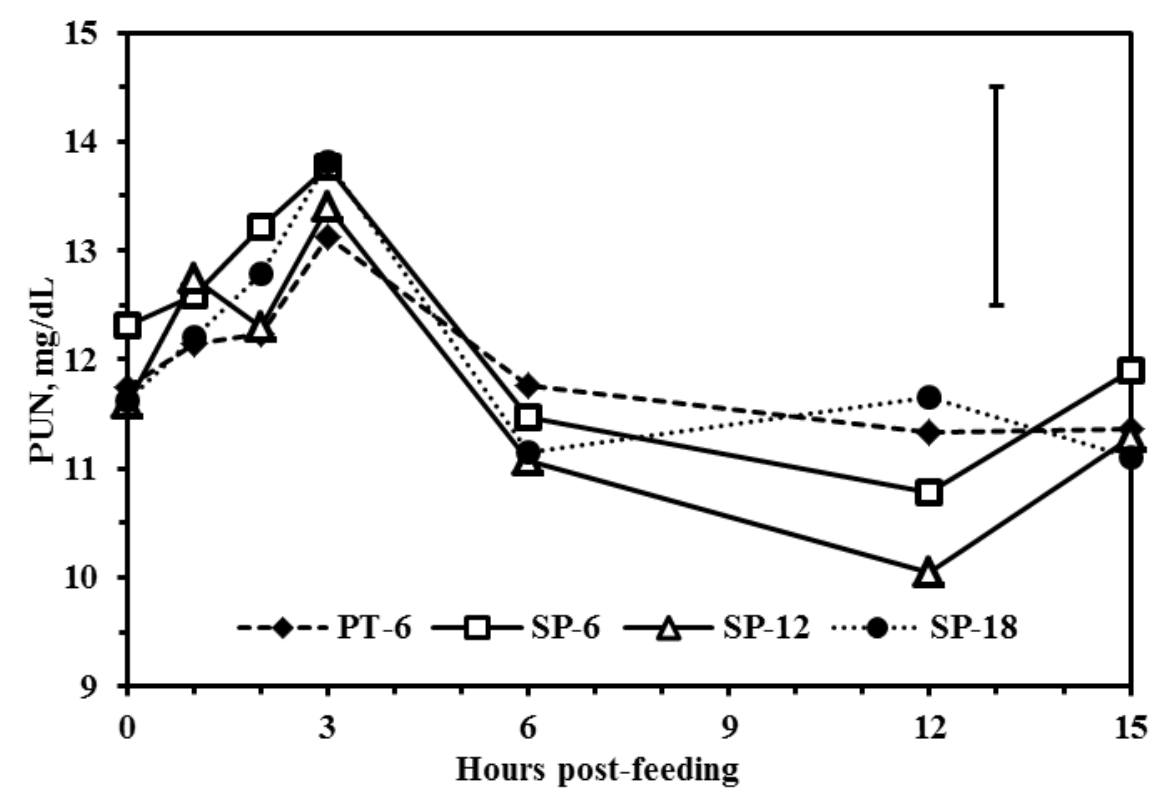

Figure 4. Plasma urea nitrogen $(\mathrm{PUN})$ at $0,1,2,3,6,12$ and $15 \mathrm{~h}$ post-feeding on treatments PT6, SP6, SP12 or SP18 (P PT6 vs. SP6 = 0.36; P SP6 vs. SP12 $=0.19 ;$ P SP12 vs. SP18 $=0.51 ;$ P treat $=0.60 ;$ P time $<0.01 ; \mathrm{P}$ treat $*$ time $=0.57 ; \mathrm{SEM}=1.77$ )

Cows in treatment PT6 had higher peNDF $>8$ intake than SP6 $(3.1 \mathrm{vs.} 2.8 \mathrm{~kg} / \mathrm{d}$; Table 20). Additionally, there was a tendency to increase $\operatorname{peNDF}_{>1.18}$ intake between these treatments (4.6 vs. $4.3 \mathrm{~kg} / \mathrm{d}$ ) as well. The treatments SP6 and SP12 differed in peNDF $>8$ intake $(2.8$ vs. $3.0 \mathrm{~kg} / \mathrm{d})$. The time spent eating did not differ among treatments. However, there was a drop in rumination time between PT6 and SP6 (- $54.7 \mathrm{~min}$ ). A tendency to increase 
rumination time (602.6 vs. $549.3 \mathrm{~min} / \mathrm{d} ; P=0.07)$ was observed in SP12 in comparison with SP6, which impacted the overall trends observed in other variables (rumination time/DMI, rumination time/NDFI, rumination time/forage NDFI and rumination time/peNDF $>1.18$ $\mathrm{min} / \mathrm{kg}$ ). Nonetheless, only SP12 tended to display higher chewing indexes (chewing time/DMI, chewing time/NDFI, chewing time/forage NDFI and chewing time/peNDF $>1.18$ ) than SP6. The resting time was reduced approximately by 68 and $65 \mathrm{~min}$ for PT6 and SP12, respectively, when these treatments were compared with SP6. The treatments did not influence the meal size, number of meals per day and duration of first ingestion. There was a selection against TMR particles between 8 - 1.18-mm at treatment SP6 (Table 21) in comparison to PT6. In addition, cows at treatment SP12 selected for TMR particles between 8 - 1.18-mm rather than SP6 (100.4 vs. $97.5 \%)$. 
Table 20. Influence of corn silage processing on feeding behavior of dairy cows ${ }^{1}$

\begin{tabular}{|c|c|c|c|c|c|c|c|c|}
\hline Item & PT6 & SP6 & SP12 & SP18 & SEM & $P \mathrm{C}_{1}^{2}$ & $P \mathrm{C}_{2}$ & $P_{3} \mathrm{C}_{3}$ \\
\hline \multicolumn{9}{|l|}{ Intake } \\
\hline $\operatorname{peNDF}_{>8}{ }^{3}$ & 3.1 & 2.8 & 3.0 & 3.1 & 0.16 & 0.01 & 0.04 & 0.42 \\
\hline peNDF $>1.18^{4}$ & 4.6 & 4.3 & 4.4 & 4.4 & 0.21 & 0.10 & 0.67 & 0.98 \\
\hline Eating, $\mathrm{min} / \mathrm{d}$ & 216.3 & 204.1 & 214.7 & 230.3 & 21.49 & 0.23 & 0.38 & 0.20 \\
\hline Eating, $\mathrm{min} / \mathrm{kg}$ of DMI & 10.9 & 10.7 & 11.1 & 12.0 & 1.09 & 0.65 & 0.46 & 0.14 \\
\hline Eating, min/kg of $\mathrm{NDFI}^{5}$ & 38.8 & 36.9 & 40.0 & 42.7 & 4.55 & 0.51 & 0.28 & 0.34 \\
\hline Eating, $\mathrm{min} / \mathrm{kg}$ of forage $\mathrm{NDFI}^{6}$ & 49.7 & 47.9 & 51.9 & 55.4 & 5.97 & 0.62 & 0.29 & 0.34 \\
\hline Eating, $\mathrm{min} / \mathrm{kg}$ of $\mathrm{iNDFI}^{7}$ & 101.4 & 108.1 & 112.8 & 114.6 & 11.5 & 0.52 & 0.66 & 0.86 \\
\hline Eating, $\mathrm{min} / \mathrm{kg}$ of $\mathrm{peNDF}>8$ & 72.6 & 75.6 & 75.9 & 76.4 & 9.95 & 0.61 & 0.96 & 0.93 \\
\hline Eating, $\mathrm{min} / \mathrm{kg}$ of $\mathrm{peNDF}>1.18$ & 48.1 & 46.2 & 51.3 & 53.9 & 6.33 & 0.62 & 0.18 & 0.48 \\
\hline Rumination, min/d & 604.0 & 549.3 & 602.6 & 617.2 & 30.12 & 0.05 & 0.07 & 0.62 \\
\hline Ruminati & 30.8 & 28.8 & 31.2 & 32.3 & 1.76 & 0.16 & 0.10 & 0.49 \\
\hline $\mathrm{l} / \mathrm{kg}$ of $\mathrm{NDFI}$ & 107.5 & 100.3 & 110.3 & 114.3 & 7.41 & 0.21 & 0.09 & 0.48 \\
\hline of forage NDFI & 139.2 & 130.3 & 143.3 & 148.5 & 9.21 & 0.23 & 0.09 & 0.47 \\
\hline Ruminati & 287.5 & 291.2 & 315.1 & 312.1 & 29.5 & 0.88 & 0.35 & 0.90 \\
\hline Rumination, $\mathrm{min} / \mathrm{kg}$ of $\mathrm{peNDF}_{>8}$ & 199.7 & 201.9 & 207.4 & 204.1 & 13.94 & 0.86 & 0.66 & 0.79 \\
\hline Rumination, $\mathrm{min} / \mathrm{kg}$ of $\mathrm{peNDF}_{>1.1}$ & 133.0 & 126.9 & 141.0 & 144.1 & 8.99 & 0.45 & 0.08 & 0.69 \\
\hline Chewing, $\min / \mathrm{d}^{8}$ & 821.6 & 753.6 & 818.9 & 849.1 & 33.65 & 0.03 & 0.04 & 0.33 \\
\hline in/kg of DMI & 41.7 & 39.6 & 42.4 & 44.4 & 1.88 & 0.16 & 0.07 & 0.19 \\
\hline Chewing, $\mathrm{min} / \mathrm{kg}$ of NDFI & 146.5 & 137.2 & 150.1 & 156.7 & 9.82 & 0.18 & 0.07 & 0.31 \\
\hline Chewing, $\mathrm{min} / \mathrm{kg}$ of forage NDFI & 189.1 & 178.4 & 195.1 & 204.1 & 12.16 & 0.23 & 0.07 & 0.31 \\
\hline $\mathrm{n} / \mathrm{kg}$ iNDFI & 388.9 & 398.7 & 426.7 & 426.5 & 34.47 & 0.77 & 0.40 & 0.99 \\
\hline Chewing, $\mathrm{min} / \mathrm{kg}$ of $\mathrm{peNDF}_{>8}$ & 273.8 & 277.8 & 271.6 & 281.0 & 19.22 & 0.77 & 0.65 & 0.49 \\
\hline Chewing, $\mathrm{min} / \mathrm{kg}$ of $\mathrm{peNDF}_{>1.18}$ & 181.7 & 173.5 & 192.4 & 198.1 & 12.98 & 0.41 & 0.06 & 0.56 \\
\hline Resting, & 617.6 & 686.4 & 621.2 & 590.6 & 33.76 & 0.02 & 0.04 & 0.34 \\
\hline Meal bouts, /d & 8.3 & 8.4 & 8.5 & 8.7 & 0.69 & 0.86 & 0.91 & 0.56 \\
\hline Meal size, $\min$ & 26.1 & 24.9 & 25.5 & 26.5 & 1.85 & 0.32 & 0.64 & 0.42 \\
\hline Duration of first meal, min & 36.5 & 33.6 & 36.4 & 40.3 & 3.19 & 0.15 & 0.31 & 0.16 \\
\hline
\end{tabular}

${ }^{1}$ Treatments were PT6 = pull-type forage harvester at theoretical length of cut (TLOC) of 6-mm without kernel processor, SP6 = self-propelled forage harvester at TLOC of $6-\mathrm{mm}, \mathrm{SP12}=$ self-propelled forage harvester at TLOC of 12-mm or SP18 = self-propelled forage harvester at TLOC of $18-\mathrm{mm}$.

${ }^{2}$ Orthogonal contrasts includes $\mathrm{C}_{1}$ - PT6 vs. SP6, $\mathrm{C}_{2}$ - SP6 vs. SP12, and $\mathrm{C}_{3}$ - SP12 vs. SP18.

${ }^{3}$ Physically effective NDF above the 8-mm PSPS sieve intake.

${ }^{4}$ Physically effective NDF above the 1.18-mm PSPS sieve intake.

${ }^{5}$ NDF intake.

${ }^{6}$ Forage NDF intake.

${ }^{7}$ Indigestible NDF intake, determined by $288 \mathrm{~h}$ of in situ incubation (Huhtanen et al., 1994).

${ }^{8}$ Chewing = Eating + Rumination. 
Table 21. Influence of corn silage processing on diet particle sorting.

\begin{tabular}{lcccccccc}
\hline Item & PT6 & \multicolumn{9}{c}{ SP6 } & SP12 & SP18 & SEM & $P \mathrm{C}_{1}{ }^{2}$ & $P \mathrm{C}_{2}$ & $P \mathrm{C}_{3}$ \\
\hline & \multicolumn{7}{c}{$\%$ of $^{2}$} & intake $^{3}$ \\
$>19-\mathrm{mm}$ & 91.5 & 91.8 & 90.3 & 94.0 & 4.42 & 0.90 & 0.66 & 0.28 \\
19-8-mm & 99.0 & 98.1 & 97.7 & 98.1 & 0.70 & 0.25 & 0.26 & 0.11 \\
$8-1.18-\mathrm{mm}$ & 99.5 & 97.5 & 100.4 & 101.0 & 1.75 & 0.05 & 0.01 & 0.55 \\
$<1.18-\mathrm{mm}$ & 106.4 & 107.8 & 106.7 & 107.1 & 1.14 & 0.43 & 0.45 & 0.79 \\
\hline
\end{tabular}

${ }^{1}$ Treatments were PT6 = pull-type forage harvester at theoretical length of cut (TLOC) of 6-mm without kernel processor, SP6 = self-propelled forage harvester at TLOC of $6-\mathrm{mm}, \mathrm{SP12}=$ self-propelled forage harvester at TLOC of 12-mm or SP18 = self-propelled forage harvester at TLOC of 18-mm.

${ }^{2}$ Orthogonal contrasts includes $\mathrm{C}_{1}$ - PT6 vs. SP6, $\mathrm{C}_{2}$ - SP6 vs. SP12, and $\mathrm{C}_{3}$ - SP12 vs. SP18.

${ }^{3}$ Values $<100 \%$ indicates selection against the particle size fraction, while values $>100 \%$ indicate selection for the particle size fraction (Leonardi and Armentano, 2003).

The treatments impacted the milk fatty acid (FA) profile (Table 22). A tendency to increase the content of C11:0, C14:0 and trans-11 C18:1 was observed between PT6 and SP6. In the same comparison (PT6 vs. SP6) a rise was perceived in the content of the following FA: C13:0, C14:1, C15:0, trans-9 C18:1 and trans-11 C18:1. Thus, the sum of linear oddchain fatty acids $(\mathrm{C} 11: 0+\mathrm{C} 13: 0+\mathrm{C} 15: 0+\mathrm{C} 17: 0)$ increased (1.46 vs. $1.60 \mathrm{~g} / 100 \mathrm{~g})$. The C4:0 content tended to reduce $(1.33$ vs. $1.24 \mathrm{~g} / 100 \mathrm{~g} ; P=0.09)$ and a significant reduction was observed for C18:0 and C20:0. In the comparison SP6 vs. SP12, a reduction in some FA was promoted by SP12. The content of C13:0, C14:1, C16:1, trans-9 C18:1 and trans-11 C18:1 was lower. The C15:0 content tended to drop. However, an increment in C18:0 content occurred for cows fed SP12. The SP18 tended to have a higher C16:0 concentration than SP12 (36.04 vs. $35.01 \mathrm{~g} / 100 \mathrm{~g}, P=0.07$ ).

The secretion $(\mathrm{g} / \mathrm{d})$ of FA varied among treatments (Table 23). The SP6 promoted higher secretion of C13:0, C14:1, C15:0 and trans-9 C18:1. The linear odd-chain FA secretion was also higher (14.75 vs. $13.19 \mathrm{~g} / \mathrm{d} ; P=0.02)$. The C11:0 and trans-11 C18:1 secretions tended to rise in the same treatment. However, a drop in C18:0 (- $11.62 \mathrm{~g}$ ) was observed, as well as a tendency of reduction for C20:0 (0.80 vs. $0.66 \mathrm{~g} / \mathrm{d} ; P=0.06)$. The SP12 cows had a lower secretion of C 13:0, C14:1 and C16:1 than SP6. Furthermore, a tendency of C15:0, trans-9 C18:1 and trans-11 C18:1 secretion reduction was observed. There was a numerical reduction in linear odd-chain FA secretion (14.75 vs. $13.76 ; P=0.13$ ) between SP6 and SP12. The SP18 did not alter the FA secretion. 
Table 22. Influence of corn silage processing on milk fatty acid profile ${ }^{1}(\mathrm{~g} / 100 \mathrm{~g})$

\begin{tabular}{|c|c|c|c|c|c|c|c|c|}
\hline Item & PT6 & SP6 & SP12 & SP18 & SEM & $P \mathrm{C}_{1}^{2}$ & $P \mathrm{C}_{2}$ & $P \mathrm{C}_{3}$ \\
\hline C4:0 & 1.33 & 1.24 & 1.30 & 1.25 & 0.069 & 0.09 & 0.31 & 0.40 \\
\hline C6:0 & 1.30 & 1.25 & 1.30 & 1.26 & 0.080 & 0.32 & 0.32 & 0.41 \\
\hline C8:0 & 0.84 & 0.83 & 0.86 & 0.83 & 0.058 & 0.80 & 0.49 & 0.39 \\
\hline C10:0 & 1.89 & 1.91 & 1.97 & 1.90 & 0.140 & 0.74 & 0.48 & 0.37 \\
\hline C11:0 & 0.04 & 0.05 & 0.06 & 0.04 & 0.007 & 0.09 & 0.90 & 0.15 \\
\hline C12:0 & 2.29 & 2.42 & 2.42 & 2.37 & 0.137 & 0.12 & 0.96 & 0.53 \\
\hline C13:0 & 0.12 & 0.15 & 0.14 & 0.13 & 0.009 & $<0.01$ & 0.04 & 0.90 \\
\hline C14:0 & 8.76 & 9.10 & 9.11 & 9.07 & 0.273 & 0.08 & 0.96 & 0.82 \\
\hline $\mathrm{C} 4-\mathrm{C} 14: 0^{3}$ & 16.40 & 16.76 & 16.96 & 16.67 & 0.700 & 0.42 & 0.66 & 0.51 \\
\hline cis-9 C14:1 & 0.94 & 1.27 & 0.97 & 1.10 & 0.098 & $<0.01$ & $<0.01$ & 0.16 \\
\hline C15:0 & 0.79 & 0.89 & 0.82 & 0.83 & 0.042 & 0.01 & 0.07 & 0.82 \\
\hline C16:0 & 35.57 & 35.56 & 35.01 & 36.04 & 0.791 & 0.99 & 0.33 & 0.07 \\
\hline cis-9 C16:1 & 1.82 & 2.29 & 1.74 & 1.95 & 0.211 & 0.01 & $<0.01$ & 0.25 \\
\hline C17:0 & 0.50 & 0.51 & 0.51 & 0.50 & 0.009 & 0.44 & 0.99 & 0.27 \\
\hline C18:0 & 9.36 & 8.05 & 8.68 & 8.54 & 0.397 & $<0.01$ & 0.09 & 0.70 \\
\hline Linear odd-chain $\mathrm{FA}^{4}$ & 1.46 & 1.60 & 1.52 & 1.51 & 0.060 & 0.01 & 0.12 & 0.76 \\
\hline trans-9 C18:1 & 0.38 & 0.45 & 0.40 & 0.43 & 0.025 & $<0.01$ & 0.04 & 0.18 \\
\hline trans-11 C18:1 & 1.29 & 1.69 & 1.20 & 1.54 & 0.242 & 0.08 & 0.03 & 0.14 \\
\hline cis-9 C18:1 & 25.00 & 24.26 & 24.49 & 23.98 & 0.830 & 0.25 & 0.72 & 0.43 \\
\hline cis- 9, trans-11 C18:2 & 0.47 & 0.49 & 0.50 & 0.53 & 0.028 & 0.63 & 0.74 & 0.26 \\
\hline C18:2n-6 & 2.41 & 2.35 & 2.41 & 2.40 & 0.094 & 0.16 & 0.19 & 0.81 \\
\hline C18:3n-3 & 0.14 & 0.14 & 0.15 & 0.14 & 0.007 & 0.96 & 0.57 & 0.92 \\
\hline C20:0 & 0.08 & 0.07 & 0.07 & 0.07 & 0.008 & 0.03 & 0.46 & 0.99 \\
\hline cis-11 C20:1n-9 & 0.04 & 0.04 & 0.04 & 0.03 & 0.004 & 0.79 & 0.77 & 0.20 \\
\hline cis-8,11,14 C20:3n-6 & 0.07 & 0.06 & 0.07 & 0.07 & 0.008 & 0.57 & 0.17 & 0.42 \\
\hline cis-5,8,11,14 C20:4n-6 & 0.12 & 0.10 & 0.12 & 0.11 & 0.010 & 0.14 & 0.03 & 0.27 \\
\hline Other fatty acids & 4.31 & 4.67 & 5.25 & 4.75 & 0.314 & 0.42 & 0.19 & 0.26 \\
\hline
\end{tabular}

${ }^{1}$ Treatments were PT6 = pull-type forage harvester at theoretical length of cut (TLOC) of 6-mm without kernel processor, SP6 = self-propelled forage harvester at TLOC of $6-\mathrm{mm}, \mathrm{SP12}=$ self-propelled forage harvester at TLOC of 12-mm or SP18 = self-propelled forage harvester at TLOC of 18-mm.

${ }^{2}$ Orthogonal contrasts includes $\mathrm{C}_{1}$ - PT6 vs. SP6, $\mathrm{C}_{2}$ - SP6 vs. SP12, and $\mathrm{C}_{3}$ - SP12 vs. SP18.

${ }^{3}$ C4:0-C14:0: C4:0, C6:0, C8:0, C10:0, C12:0, C14:0.

${ }^{4}$ Linear odd-chain fatty acids: C11:0, C13:0, C15:0, C17:0. 
Table 23. Milk fatty acids as daily secretion (Assumes milk fat is $93.3 \%$ fatty acids and $6.7 \%$ glycerol $)^{1}(\mathrm{~g} / \mathrm{d})$

\begin{tabular}{lcccccccc}
\hline Item & PT6 & SP6 & SP12 & SP18 & SEM & $P C_{1}^{2}$ & $P C_{2}$ & $P C_{3}$ \\
\hline C4:0 & 12.57 & 11.88 & 11.93 & 11.72 & 1.230 & 0.32 & 0.95 & 0.76 \\
C6:0 & 12.38 & 12.02 & 12.07 & 11.93 & 1.314 & 0.57 & 0.94 & 0.82 \\
C8:0 & 8.00 & 7.97 & 7.95 & 7.84 & 0.919 & 0.95 & 0.95 & 0.80 \\
C10:0 & 17.94 & 18.23 & 18.26 & 17.98 & 2.162 & 0.75 & 0.98 & 0.77 \\
C11:0 & 0.37 & 0.51 & 0.50 & 0.40 & 0.078 & 0.06 & 0.87 & 0.18 \\
C12:0 & 21.44 & 22.77 & 22.31 & 22.07 & 2.308 & 0.20 & 0.66 & 0.82 \\
C13:0 & 1.11 & 1.39 & 1.22 & 1.21 & 0.123 & $<0.01$ & 0.04 & 0.86 \\
C14:0 & 80.98 & 84.80 & 83.45 & 83.49 & 6.641 & 0.22 & 0.66 & 0.99 \\
C4-C14:0 & 153.26 & 157.66 & 155.96 & 155.04 & 14.331 & 0.49 & 0.79 & 0.88 \\
cis-9 C14:1 & 8.27 & 11.22 & 8.81 & 9.59 & 0.858 & $<0.01$ & 0.01 & 0.39 \\
C15:0 & 7.13 & 8.13 & 7.43 & 7.40 & 0.530 & 0.01 & 0.08 & 0.94 \\
C16:0 & 323.25 & 328.27 & 318.07 & 326.96 & 16.623 & 0.65 & 0.36 & 0.43 \\
cis-9 C16:1 & 15.80 & 20.11 & 15.58 & 16.90 & 1.673 & 0.02 & 0.01 & 0.45 \\
C17:0 & 4.58 & 4.72 & 4.61 & 4.53 & 0.317 & 0.48 & 0.57 & 0.66 \\
C18:0 & 87.54 & 75.92 & 79.47 & 79.41 & 7.170 & 0.01 & 0.40 & 0.99 \\
Linear odd-chain FA & 13.19 & 14.75 & 13.76 & 13.53 & 0.978 & 0.02 & 0.13 & 0.71 \\
trans-9 C18:1 & 3.38 & 3.99 & 3.61 & 3.80 & 0.349 & $<0.01$ & 0.06 & 0.34 \\
trans-11 C18:1 & 10.95 & 14.62 & 10.69 & 13.01 & 2.205 & 0.07 & 0.06 & 0.25 \\
cis-9 C18:1 & 228.51 & 224.57 & 221.10 & 217.33 & 16.865 & 0.72 & 0.75 & 0.73 \\
cis-9, trans-11 C18:2 & 4.38 & 4.52 & 4.52 & 4.89 & 0.371 & 0.65 & 0.99 & 0.25 \\
C18:2n-6 & 22.17 & 21.70 & 21.86 & 21.97 & 1.919 & 0.61 & 0.86 & 0.90 \\
C18:3n-3 & 1.30 & 1.31 & 1.32 & 1.33 & 0.119 & 0.87 & 0.91 & 0.91 \\
C20:0 & 0.80 & 0.66 & 0.68 & 0.72 & 0.089 & 0.06 & 0.74 & 0.60 \\
cis-11 C20:1n-9 & 0.34 & 0.34 & 0.33 & 0.26 & 0.043 & 0.97 & 0.75 & 0.15 \\
cis-8,11,14 C20:3n-6 & 0.64 & 0.62 & 0.67 & 0.65 & 0.095 & 0.69 & 0.45 & 0.80 \\
cis-5,8,11,14 C20:4n-6 & 1.09 & 0.99 & 1.12 & 1.06 & 0.125 & 0.27 & 0.17 & 0.54 \\
Other fatty acids & 39.26 & 42.72 & 48.06 & 42.68 & 4.780 & 0.47 & 0.26 & 0.26 \\
\hline
\end{tabular}

${ }^{1}$ Treatments were PT6 = pull-type forage harvester at theoretical length of cut (TLOC) of 6-mm without kernel processor, SP6 = self-propelled forage harvester at TLOC of 6-mm, SP12 = self-propelled forage harvester at TLOC of 12-mm or SP18 = self-propelled forage harvester at TLOC of 18-mm. ${ }^{2}$ Orthogonal contrasts includes $\mathrm{C}_{1}$ - PT6 vs. SP6, $\mathrm{C}_{2}$ - SP6 vs. SP12, and $\mathrm{C}_{3}$ - SP12 vs.SP18. ${ }^{3}$ C4:0-C14:0: C4:0, C6:0, C8:0, C10:0, C12:0, C14:0.

${ }^{4}$ Linear odd-chain fatty acids: C11:0, C13:0, C15:0, C17:0.

\subsection{DISCUSSION}

The fermentation profile of WPCS was adequate and in accordance to the guidelines suggested by Kung et al. (2018). The nutrient composition of WPCS (\% DM) - 32.1\% starch and $43.8 \% \mathrm{NDF}$ - represents high quality corn silage for international standards (Owens, 2014). However, the kernel processing score of PT6 (32.1\%), SP12 (49.0\%) and SP18 (40.1\%) were less than $50 \%$ and are classified as inadequately processed according to Shinners and Holmes (2013). Just the SP6 (53.9\%) was adequately processed. When 
comparing samples based on the orthogonal contrasts, there was a great difference in CSPS among comparisons. The $\mathrm{C}_{1}$ (PT6 vs. SP6) had a numerical difference of 21.8 percentage units, $\mathrm{C}_{2}$ (SP6 vs. SP12) of 4.9 percentage units and $\mathrm{C}_{3}$ (SP12 vs. SP18) of 8.9 percentage units (Table 3).

The major difference in particle size was observed at the upper PSPS sieve. There was a reduction of $55.5 \%$ of WPCS at percentage retained above a 19-mm sieve of PSPS at the same TLOC (PT6 vs. SP6). Ferraretto et al. (2018) reported, in a recent literature review that mechanical processing is able to reduce $20 \%$ of WPCS particles retained above 18- or 19mm sieves of particle separators. As a consequence, the MPL of WPCS SP6 was lower than PT6 by $8 \%$. Shinners et al. (2000) reported a drop in MPL for processed WPCS, which can be explained by the crushing and shearing action of the kernel processor (Johnson et al., 2002).

Greater milk production $(+1.2 \mathrm{~kg})$ at SP6 was partially related to the greater apparent TTSD (+ 2.2 percentage units). Bal et al. (2000) reported an increase of $1.2 \mathrm{~kg}$ in milk yield followed by greater DMI $(+0.6 \mathrm{~kg})$, ruminal $(+19.3$ percentage units $)$ and totaltract $(+4.2$ percentage units) starch digestibility for cows fed with processed WPCS harvested at TLOC of 9.5-mm. Ferraretto and Shaver (2012) performed a meta-analysis of peerreviewed papers about the influence of kernel processing on dairy cow performance and nutrient digestibility. WPCS processed at 1 to $3-\mathrm{mm}$ or unprocessed displayed a trend toward greater milk yield $(+1.8 \mathrm{~kg} / \mathrm{cow} / \mathrm{d})$ in comparison with WPCS processed at 4 to 8 -mm. However, no differences in milk yield were observed between WPCS processed at 1 to 3-mm and unprocessed silage. Kernel processing with rollers set at 1 to 3-mm increased TTSD by 5.9 percentage units when compared to 4 to 8 - $\mathrm{mm}$ processed WPCS, and increased by 2.8 percentage units when compared to unprocessed WPCS. The pericarp of corn kernel is poorly digested by rumen bacteria with minimal post ruminal digestion potential (Giuberti et al., 2014). Therefore, kernel damage during its passage through the rollers fractures pericarp and disrupts the dense protein matrix where starch is embedded (Johnson et al., 2002). Thereby, increased bacterial attachment and digestion (Huntington, 1997) improves TTSD.

The longest TLOC (SP18) tended to reduce milk yield followed by a tendency of lower TTSD in comparison with SP12. This lower TTSD at a longer TLOC WPCS (SP18) may be related to the longer fiber fraction reducing kernel breakage during the processing of WPCS through the rollers at harvest as described by Ferraretto and Shaver (2012). Besides TLOC, other factors including endosperm properties (Correa et al., 2002; Ferraretto and Shaver, 2012), maturity (Johnson et al., 2002), and processing degree (Bal et al., 2000) of 
WPCS can alter the fragmentation of kernels and also, as a consequence, TTSD (Cooke and Bernard, 2005). The TLOC of 19-mm and a roll gap of 1 to 3-mm have been recommended in the USA (Shinners et al., 2000) for the last decades, however in this trial the $18-\mathrm{mm}$ tended to impair TTSD and milk yield. Ferraretto and Shaver (2012) reported a drop in TTSD just when WPCS was harvested at a TLOC above 32.0- $\mathrm{mm}$. The vitreous endosperm hybrids may require lower TLOC settings due to the hardness of the kernel which makes it more difficult to be broken. There is a lack of information regarding the right TLOC and roll gap settings for each type of kernel processor in distinct scenarios (maturity and hybrids) and further research is warranted.

The impact of kernel processing and TLOC in milk fat is inconsistent in the literature. Ferraretto and Shaver (2012) reported greater milk fat content for unprocessed WPCS (3.55\%) than processed at a roll gap of 1 to 3-mm (3.44\%). Conversely, Shinners et al. (2000) observed greater fat content for cows fed processed WPCS and attributed this to less sorting of the cob fiber in the bunk. In our trial, there was just a numerical difference in milk fat content between PT6 and SP6 (3.52 vs. 3.37\%). The milk fat content did not change within SPFH treatments (SP6, SP12, and SP18) at different TLOCs. The meta-analysis conducted by Nasrollahi et al. (2015) with purpose to evaluate the impact of TMR MPL in the performance of dairy cows revealed a reduction of 0.06 percentage units in fat content when cows were fed finer particles. A similar ruminal VFA profile for WPCS with varying TLOCs have been reported (Bal et al., 2000; Onetti et al., 2003) and may explain the lack of effect of TLOC on milk fat content (Ferraretto and Shaver, 2012). Greater ruminal propionate concentrations for cows fed processed WPCS had been reported (Dhiman et al., 2000; Schwab et al., 2002), however the ruminal VFA were unaffected in our trial.

Despite the similar milk protein content (3.32 vs. 3.31\%) of these treatments (SP6 and PT6) the milk protein yield was improved for processed WPCS. A consistent improvement in milk protein yield when cows are fed processed WPCS has been observed (Johnson et al., 1999), but not in milk protein content (Ferraretto and Shaver et al., 2012). Lower MUN was noted in SP6 which may be related to increased ruminal starch digestibility (Ferraretto and Shaver, 2012) and thus improved ruminal nitrogen utilization (NRC, 2001). Schwab et al. (2002) observed a reduction of $1.2 \mathrm{mg} / \mathrm{dL}$ in MUN for processed WPCS. The SP6 had greater milk protein content than SP12. The effect of particle size in milk protein content is contradictory. Ferraretto and Shaver (2012) did not find an effect of TLOC; however, greater protein content has been reported for cows fed finer particles (Nasrollahi et al., 2015). The lactose content was lower for SP18 and milk yield tended to be reduced in 
comparison with SP12; thereby the lactose excretion per day was also reduced. Enhanced glucose availability to the mammary gland in response to kernel processing at specific TLOC settings (SP6 and SP12) appears to have increased lactose synthesis, resulting in a positive milk yield response. The gains in nutrient digestibility contribute to the enhancement in milk yield. Greater OMD for cows fed processed WPCS has been reported, however no impact for DMD and NDFD was observed (Ferraretto and Shaver, 2012).

The plasma glucose concentration increased by $4.1 \mathrm{mg} / \mathrm{dL}$ in SP6 compared with PT6. Cooke and Bernard (2005) also reported greater plasma glucose levels in dairy cows fed processed WPCS. Plasma glucose is influenced by ruminal propionate proportions (Vlaeminck et al., 2004) or duodenal glucose absorption (Nocek and Tamminga, 1991). This increment in plasma glucose can stimulate the lactose synthesis in the mammary gland, and as a consequence, the milk yield. Despite low MUN, PUN, ruminal $\mathrm{N}-\mathrm{NH}_{3}$ purine derivatives were unaffected. Dhiman et al. (2000) reported lower ruminal $\mathrm{N}-\mathrm{NH}_{3}$ in cows fed processed WPCS, however no impact in PUN was observed. Ouellet et al. (2003) reported that PUN and purine derivatives were not affected by kernel processing, however PUN varied throughout the day and peaked at 3-h after feeding. These results are in accordance with our PUN results.

The DMI was unaffected among the treatments despite the distinct particle size, peNDF $_{>8}$ and peNDF$_{>1.18}$ content in the diets. Ferraretto and Shaver (2012) reported no effect of kernel processing and TLOC on DMI. However, Nasrollahi et al. (2015) observed through a meta-analysis of 46 studies that the decrease in MPL enhanced DMI and this effect was pronounced in diets containing high levels of forage (>50\% of DM). Summarizing studies conducted mainly with WPCS as the forage source revealed that when TLOC was reduced from $23.3 \pm 8.22-\mathrm{mm}$ to $10.2 \pm 6.78-\mathrm{mm}$ the DMI was increased by $0.6 \mathrm{~kg}$ ranging from -1.1 $\mathrm{kg}$ to $+2.3 \mathrm{~kg} / \mathrm{d}$ (Zebeli and Humer, 2017).

Feeding dairy cows less than $18.5 \%$ of peNDF $_{>8}$ or $31.2 \%$ of peNDF $>1.18$ poses an imminent risk of SARA (Zebeli et al. 2012). The SP6 consumed diet had the lowest peNDF $>8$ content among treatments $(14.4 \%)$ and when cows were fed this diet a trend of higher plasma D-lactate (1.56 vs. $1.38 \mathrm{~m} M, P=0.10)$ and SAA $(6.0$ vs. $4.1 \mu \mathrm{g} / \mathrm{mL})$ was observed in comparison with SP12. Moreover, SP6 cows selected against particles retained between 8 and 1.18-mm sieve of PSPS (97.5 vs. 100.4\%). The kernel processing of WPCS improves ruminal starch digestibility (Ferraretto and Shaver, 2012), reduces long particles (Ferraretto et al. 2018) possibly reducing rumen $\mathrm{pH}$ (Onetti et al., 2003) and thereby cows would be prone to SARA. The peNDF impacts chewing activity, ruminal $\mathrm{pH}$ and milk fat content (Mertens, 
1997). Despite a trend for diminishment in rumination and chewing times between SP6 and SP12, the ruminal $\mathrm{pH}$ and milk fat content was not impacted.

A rise in peNDF $>8$ intake was observed between SP6 and SP12 (2.8 vs. $3.0 \mathrm{~kg} / \mathrm{d})$. This higher intake of peNDF may have contributed for the tendency to reduction in plasma Dlactate and SAA. Improvements in rumination activity, salivary buffering, and rumen mat formation by higher peNDF intake have been reported in literature (Zebeli et al. 2012). Chewing increases salivary secretion in dairy cows and also helps to reduce the risk of SARA (Beauchemin, 2018). The higher rumination and chewing times may have promoted more saliva secretion and consequently helped in rumen buffering.

The increase of long particles in TMR $(\geq 19-\mathrm{mm})$ affects the eating time (Beauchemin, 2018) due to increase necessary chewing to swallow a bolus of feed (Grant and Ferraretto, 2018). Furthermore, these particles retained on the 19-mm sieve of PSPS are most likely to be sorted by dairy cows (Kononoff and Heinrichs, 2003a). The treatments had different TMR long particles percentages (5.3, 2.7, 6.7 and 15.5\%; Table 1) and MPL, however the eating time, duration of the first meal, and sorting against long particles were unaffected. Bal et al. (2000) did not find different eating, ruminating and chewing times for cows fed processed WPCS harvested at several TLOC $(9.5,14.5$ and 19-mm) or unprocessed at TLOC of $9.5 \mathrm{~mm}$. Kononoff et al. (2003c) also reported no effect of particle size on feeding behavior when a TMR containing 57.4\%WPCS was fed for dairy cows.

Higher intake of medium particles (4-19-mm) impacts rumination time (Beauchemin, 2018). The peNDF $_{>8}$ intake ( 3.1 vs. $2.8 \mathrm{~kg} / \mathrm{d}$ ) was higher and trended to increase peNDF $>1.18$ intake (4.6 vs. $4.3 \mathrm{~kg} / \mathrm{d}$ ) for PT6. The higher intake of peNDF for PT6 is in accordance with the higher ruminating time (604 vs. $549 \mathrm{~min}$ ) in this treatment. The SP12 cows had a greater peNDF $_{>8}$ intake than SP6 (3.0 vs. $\left.2.8 \mathrm{~kg} / \mathrm{d}\right)$ and it may have influenced the trend for greater rumination time (602.6 vs. $549.3 \mathrm{~min}$ ). Nasrollahi et al. (2016), in a meta-analysis of 86 published studies, reported that the decreasing forage MPL in dairy cow diets between an average of $10 \pm 4.9$ to $6.7 \pm 4.1-\mathrm{mm}$ reduced eating, rumination and chewing time by 19,28 and $44 \mathrm{~min} / \mathrm{d}$, respectively. The MPL of PT6 and SP12 diets were close (5.8 vs. 5.7-mm), as well as the rumination time (604 vs. $602.6 \mathrm{~min}$ ) and chewing time ( 821.6 vs. $818.9 \mathrm{~min})$. Both of these treatments (PT6 and SP12) were different or tended to be different from SP6 probably due to the lower SP6 MPL (5.0-mm) that led to a reduction in rumination and chewing time which lead to a rise in resting time. A trend for a reduction in chewing index between SP6 and SP12 could be explained by the different MPL. Lower chewing index (expressed as minutes of chewing per kilogram of DM ingested) has been reported when MPL 
is shortened (Grant and Ferraretto, 2018). The feeding behavior results may have contributed to higher SAA values for SP6 cows.

Kernel-induced SARA led to an increment at levels of SAA followed by a higher free lipopolysaccharide (LPS) in rumen fluid (Gozho et al., 2007; Khafipuor et al., 2009). The SAA belongs to the class of acute phase proteins and its increase in the bloodstream indicates acute phase response to inflammation (Horadagoda et al., 1999). The inflammation can be caused by dietary-induced damage to the gut mucosa or by translocation of immunogenic compounds (e.g. free LPS) into circulation (Horadagoda et al., 1999). Gozho et al. (2007) and Khapifour et al. (2009) considered SARA when $\mathrm{pH}$ reduces below 5.6 for prolonged periods (> $3 \mathrm{~h}$ ). We did not measure ruminal $\mathrm{pH}$ throughout the day; therefore it is not possible to confirm that SP6 cows suffered SARA. However, D-lactate and SAA results indicate a potential blood acidotic status and acute phase response, respectively, for SP6 cows.

The C4:0 FA content tended to reduce in SP6. This FA is produced in the mammary gland by de novo synthesis. The main pathway involves acetate being converted to acetyl CoA by acetyl CoA synthetase. Then, acetyl-CoA carboxylase (ACC) converts acetyl-CoA to malonyl-CoA (Bauman and Davis, 1974). Baumgard et al. (2002) reported decay of C4:0 content in milk fat after abomasal infusion of trans-10, cis-12 C18:2 followed by a reduction of the abundance of mRNA of ACC, fatty acid synthetase and $\Delta-9$ desaturase enzymes in mammary gland. However, the content of trans-10, cis-12 C18:2 was low which precluded its detection by the method. A greater linear odd-chain FA content for SP6 than PT6 was observed. The linear odd-chain FA are formed in rumen when propionyl-CoA is used as a primer (Kaneda, 1991). Vlaeminck et al. (2006) reported that linear odd-chain FA is mainly synthetized in the rumen and partially in the mammary gland. However, the propionate proportion in rumen was unaffected by these treatments. The response of linear odd-chain FA to inclusion of WPCS in the diets is inconsistent in literature (Vlaeminck et al., 2006).

Vlaeminck et al. (2006) suggested a possible greater $\Delta-9$ desaturase activity induced by higher blood glucose levels (Ntambi and Miyazaki, 2004). This is a possible explanation for higher content of C14:1 and C 16:1 FA observed at SP6 cows in comparison with PT6. However, this theory failed when SP6 and SP12 were compared as they had the same plasma glucose contents. However, a drop in C14:1 and C 16:1 FA content was observed in SP12. The drop in trans-9 C18:1 and trans-11 C18:1 was followed by an increase in C18:0 concentrations for SP12 and PT6 in comparison with SP6. This can be indicative of a better ruminal environment which allows the complete biohydrogenation of FA. Onetti et al. (2003) 
reported no effect in trans-9 $\mathrm{C} 18: 1$ and trans-11 C18:1 contents when cows were fed processed WPCS harvested at 19 and 32-mm TLOC.

\subsection{CONCLUSIONS}

Kernel processing at TLOC settings of 6-mm and 12-mm enhanced nutrient digestibility, plasma glucose and milk yield. The enhanced glucose availability to the mammary gland likely increased lactose synthesis, resulting in a positive milk yield response. Nevertheless, at 18-mm TLOC, the processing was poor and possibly impaired lactation performance. The SP12 improved chewing time and reduced blood sub-acute acidotic markers. Thereby, SP12 appeared to be the best setting to harvest WPCS from vitreous corn endosperm hybrids. Additionally, more aggressive kernel processors to achieve excellent kernel processing scores $(>70 \%)$ for Brazilian corn hybrids are necessary.

The SP6 led a rise in milk linear odd-chain FA content in comparison with PT6. Nonetheless, a reduction occurred at SP12. Kernel processing induced higher content of some monounsaturated FA (C14:1 and C16:1) at TLOC of 6-mm, however the opposite happened for SP12. The possible explanations for these results are still unclear. More detailed studies to investigate the effects of kernel processing and particle size in milk fat profile are warranted.

\section{LITERATURE CITED}

Allen, M. S., J. G. Coors, and G. W. Roth. 2003. Corn silage. Pages 547-608 in Silage Science and Technology. D. R. Buxton, R. E. Muck, and H. J. Harrison, ed. ASA, CSA, and SSSA, Madison, WI.

Ametaj, B. N., B. J. Bradford, G. Bobe, R. A. Nafikov, Y. Lu, J. W. Young, and D. C. Beitz. 2005. Strong relationship between mediators of the acute phase response and fatty liver in dairy cows. Can. J. Anim. Sci. 85:165-175.

AOAC International. 2012. Official Methods of Analysis. 19th ed. AOAC International, Arlington, VA.

Bal, M. A., R. D. Shaver, A. G. Jirovec, K. J. Shinners, and J. G. Coors. 2000. Crop processing and chop length of corn silage: Effects on intake, digestion, and milk production by dairy cows. J. Dairy Sci. 83:1264-1273.

Baker, S., and T. Herrman. 2002. Evaluating particle size. MF-2051. Kansas State Univ., Manhattan. 
Baumgard, L. H., E. Matitashvili, B. A. Corl, D. A. Dwyer, and D. E. Bauman. 2002. Trans10, cis-12 conjugated linoleic acid decreases lipogenic rates and expression of genes involved in milk lipid synthesis in dairy cows. J. Dairy Sci. 85:2155-2163

Bauman, D.E., and C.L. Davis. 1974. Biosynthesis of milk fat. In: B. L. Larson, and V. R. Smith (Eds.) Lactation: A Comprehensive Treatise. Vol. 2. Academic Press, New York, p. 31- 75 .

Bernardes, T. F., and A. C. Rego. 2014. Study on the practices of silage production and utilization on Brazilian dairy farms. J. Dairy Sci. 97:1852-1861.

Bernardes, T. F., J. L. P. Daniel, A. T. Adesogan, T. A. McAllister, P. Drouin, L. G. Nussio, P. Huhtanen, G. F. Tremblay, G. Bélanger, and Y. Cai. 2018. Silage review: Unique challenges of silages made in hot and cold regions. J. Dairy Sci. 101:4001-4019.

Chaney, A. L., and E. P. Marbach. 1962. Modified reagents for determination of urea and ammonia. Clin. Chem. 8:130-137.

Chen, X. B., and M. J. Gomes. 1992. Estimation of microbial protein supply to sheep and cattle based on urinary excretion of purine derivatives: An overview of technical details. Int. Feed Res. Unit, Occasional Publ. Rowett Research Institute, Aberdeen, United Kingdom.

Chizzotti, M. L., F. S. Machado, E. E. L. Valente, L. G. R. Pereira, M. M. Campos, T. R. Tomich, S. G. Coelho, and M. N. Ribas. 2015. Technical note: Validation of a system for monitoring individual feeding behavior and individual feed intake in dairy cattle. J. Dairy Sci. 98:3438-3442.

Chizzotti, M. L., S. C. Valadares Filho, R. F. D. Valadares, F. H. M. Chizzotti, and L. O. Tedeschi. 2008. Determination of creatinine excretion and evaluation of spot urine sampling in Holstein cattle. Livest. Sci. 113:218-225.

Correa, C. E. S., R. D. Shaver, M. N. Pereira, J. G. Lauer, and K. Kohn. 2002. Relationship between corn vitreousness and ruminal in situ starch degradability. J. Dairy Sci. 85:30083012 .

Cooke, K. M., and J. K. Bernard. 2005. Effect of kernel processing and theoretical length of cut of corn silage on performance of lactating dairy cows. J. Dairy Sci. 88:310-316.

Der Bedrosian, M. C., L. Kung Jr., and K. E. Nestor Jr.. 2012. The effects of hybrid, maturity and length of storage on the composition and nutritive value of corn silage. J. Dairy Sci. 95:5115-5126. 
Dias Junior, G. S., L. F. Ferraretto, G. G. S. Salvati, L. C. de Resende, P. C. Hoffman, M. N. Pereira, and R. D. Shaver. 2016. Relationship between processing score and kernelfraction particle size in whole-plant corn silage. J. Dairy Sci. 99:2719-2729.

Dombrink-Kurtzman, M. A., and J. A. Bietz. 1993. Zein composition in hard and soft endosperm of maize. Cereal Chem. 70:105-108.

Ferraretto, L. F., and R. D. Shaver. 2012. Meta-analysis: Impact of corn silage harvest practice on intake, digestion and milk production by dairy cows. Prof. Anim. Sci. 28:141149.

Ferraretto, L. F., R. D. Shaver, and B. D. Luck. 2018. Silage review: Recent advances and future technologies for whole-plant and fractionated corn silage harvesting. J. Dairy Sci. 101:3937-3951.

Ferreira, G., and D. R. Mertens. 2005. Chemical and physical characteristics of corn silages and their effects on in vitro disappearance. J. Dairy Sci. 88:4414-4425.

Ferreira, E. M., A. V. Pires, I. Susin, M. V. Biehl, R. S. Gentil, M. O. M. Parente, D. M. Polizel, C. V. M. R. Ribeiro, and E. Almeida. 2016. Nutrient digestibility and ruminal fatty acid metabolism in lambs supplemented with soybean oil partially replaced by fish oil blend. Anim. Feed Sci. Technol. 216:30-39.

Feng, S., A. L. Lock and P. C. Garnsworthy. 2004. Technical note: a rapid lipid separation method for determining fatty acid composition of milk. J. Dairy Sci. 87:3785-3788.

Giuberti, G., A. Gallo, F. Masoero, L. F. Ferraretto, P. C. Hoffman, and R. D. Shaver. 2014. Factors affecting starch utilization in large animal food production system: A review. Starke (Weinheim) 66:72-90.

Grant, R. J, and L. F. Ferraretto. Silage review: Silage feeding management: Silage characteristics and dairy cow feeding behavior. J. Dairy Sci. 101:4111-4121.

Gozho, G. N., D. O. Krause, and J. C. Plaizier. 2007. Ruminal lipopolysaccharide concentration and inflammatory response during kernel-induced subacute ruminal acidosis in dairy cows. J. Dairy Sci. 90:856-866.

Horadagoda, N. U., K. M. Knox, H. A. Gibbs, S. W. Reid, A. Horadagoda, S. E. Edwards, and P. D. Eckersall. 1999. Acute phase proteins in cattle: Discrimination between acute and chronic inflammation. Vet. Rec. 144:437-441.

Huhtanen, P., K. Kaustell and S. Jaakkola. 1994. The use of internal markers to predict total digestibility and duodenal flow of nutrients in cattle given six different diets. Anim. Feed Sci. Technol. 48: 211-227 
Hall, M. B. 2015. Determination of dietary starch in animal feeds and pet food by an enzymatic-colorimetric method. Collaborative study. J. AOAC Int. 98:397-409.

Huntington, G. B. 1997. Starch utilization by ruminants: From basics to the bunk. J. Anim. Sci. 75:852-867.

Jenkins, T. C. 2004. Challenges of Meeting Cow Demands for Omega Fatty Acids.Pages 5266 in Proc. Florida Ruminant Nutrition Symposium.

Johnson, L., J. H. Harrison, C. Hunt, K. Shinners, C. G. Doggett, and D. Sapienza. 1999. Nutritive value of corn silage as affected by maturity and mechanical processing: A contemporary review. J. Dairy Sci. 82:2813-2825.

Johnson, L. M., J. H. Harrison, D. Davidson, W. C. Mahanna, and K. Shinners. 2003. Corn silage management: Effects of hybrid, chop length, and mechanical processing on digestion and energy content. J. Dairy Sci. 86:208-231.

Johnson, L. M., J. H. Harrison, D. Davidson, J. L. Robutti, M. Swift, W. C. Mahanna, and K. Shinners. 2002. Corn silage management I: Effects of hybrid, maturity, and mechanical processing on chemical and physical characteristics. J. Dairy Sci. 85:833-853.

Kaneda, T. 1991. Iso- and anteiso-fatty acids in bacteria: biosynthesis, function, and taxonomic significance. Microbiol. Rev. 55: 288-302.

Khafipour, E., D. O. Krause, and J. C. Plaizier. 2009. A kernel-based subacute ruminal acidosis challenge causes translocation of lipopolysaccharide and triggers inflammation. J. Dairy Sci. 92:1060-1070.

Kramer, J. K. G., V. Fellner, and M. E. R. Dugan. 1997. Evaluating acid and base catalysts in the methylation of milk and rumen fatty acids with special emphasis on conjugated dienes and total trans fatty acids. Lipids 32:1219-1228.

Kononoff, P. J., and A. J. Heinrichs. 2003a. The effect of reducing alfalfa haylage particle size on cows in early lactation. J. Dairy Sci.86:1445-1457.

Kononoff, P. J., A. J. Heinrichs, and D. R. Buckmaster. 2003b. Modification of the Penn State forage and total mixed ration particle separator and the effects of moisture content on its measurements.J. Dairy Sci. 86:1858-1863.

Kononoff, P. J., A. J. Heinrichs, and H. A. Lehman. 2003c. The effect of corn silage particle size on eating behavior, chewing activities, and rumen fermentation in lactating dairy cows. J. Dairy Sci.86:3343-3353.

Kung, L., Jr., R. Shaver, R. J. Grant, and R. J. Schmidt. 2018. Silage review: Interpretation of chemical, microbial, and organoleptic components of silages. J. Dairy Sci. 101:4020-4033. 
Lammers, B. P., D. R. Buckmaster, and A. J. Heinrichs. 1996. A simple method for the analysis of particle sizes of forage and total mixed rations. J. Dairy Sci. 79:922-928.

Leonardi, C., and L. E. Armentano. 2003. Effect of quantity, quality and length of alfalfa hay on selective consumption by dairy cows. J. Dairy Sci. 86:557-564.

Martin, N. P., M. P. Russelle, J. M. Powell, C. J. Sniffen, S. I. Smith, J. M. Tricarico, and R. J. Grant. 2017. Invited review: Sustainable forage and kernel crop production for the US dairy industry. J. Dairy Sci. 100:9479-9494.

Mertens, D. R. 1997. Creating a system for meeting the fiber requirements of dairy cows. J. Dairy Sci. 80:1463-1481.

National Research Council. 2001. Nutrient requirements of dairy cattle. $7^{\text {th }}$ rev. ed. Natl. Acad. Sci., Washington D.C.

Nasrollahi, S. M., M. Imani, Q. Zebeli. 2015. A meta-analysis and meta-regression of the effect of forage particle size, level, source and preservation method of forages on feed intake, nutrient digestibility, and performance in dairy cows. J. Dairy Sci. 98:8926-8939.

Nasrollahi, S. M., M. Imani, Q. Zebeli. 2016. A meta-analysis and meta-regression of the impact of particle size, level, source and preservation method of forages on chewing behavior and ruminal fermentation in dairy cows. Anim. Feed Sci. Technol. 219:144-158.

Nigon, B. J., K. J. Shinners, and D. E. Cook. 2016. Harvester modifications to alter composition and dry matter of corn-silage. Appl. Eng. Agric. 32:157-167.

Nocek, J.E., and S. Tamminga. 1991. Site of digestion of starch in the gastrointestinal tract of dairy cows and its effect on milk yield and composition. J. Dairy Sci. 74:3598-3629.

Ntambi, J.M., Miyazaki, M., 2004. Regulation of stearoyl-CoA desaturases and role in metabolism.Prog. Lipid Res. 43:91-104.

Onetti, S. G., R. D. Shaver, S. J. Bertics, and R. R. Grummer. 2003. Influence of corn silage particle length on the performance of lactating dairy cows fed supplemental tallow. J. Dairy Sci. 86:2949-2957.

Ouellet, D. R., H. Lapierre, and J. Chiquette. 2003. Effects of corn silage processing and amino acid supplementation on the performance of lactating dairy cows. J. Dairy Sci. 86:3675-3684.

Owens, F. 2014. New technologies in forage varieties and production. Pages 103-121 in Proc. Tri-State Dairy Nutr.Conf., Ft. Wayne, IN. Ohio State Univ., Columbus.

Philippeau, C., and B. Michalet-Doreau. 1998. Influence of genotype and ensiling of corn kernel on in situ degradation of starch in the rumen. J. Dairy Sci. 81:2178-2184. 
Pryce, J. D. 1969. A modification of Barker-Summerson method for determination of lactic acid. Analyst. 94:1151-1152.

Savoie, P., K. J. Shinners, and B. N. Binversie. 2004. Hydrodynamic separation of kernel and stover components in corn silage. Appl. Biochem. Biotechnol. 113-116:41-54.

Schwab, E. C., R. D. Shaver, K. J. Shinners, J. G. Lauer, and J. G. Coors. 2002. Processing and chop length effects in brown-midrib corn silage on intake, digestion, and milk production by dairy cows. J. Dairy Sci. 85:613-623.

Shinners, K. J. 2003. Engineering principles of silage harvesting equipment. Pages 361-403 in Silage Science and Technology. D. R. Buxton, R. E. Muck, and H. J. Harrison, ed. ASA, CSA, and SSSA, Madison, WI.

Shinners, K. J., and B. J. Holmes. 2013. Making sure your kernel processor is doing its job. Focus on Forage, 15:1-3. Accessed January 20, 2019. http:// fyi .uwex .edu/ forage/ files/ 2014/ 01/ KernelProcessing-FOF .pdf.

Shinners, K. J., A. G. Jirovec, R. D. Shaver, and M. Bal. 2000.Processing whole-plant corn silage with crop processing rolls on a pull-type forage harvester. Appl. Eng. Agric. $16: 323-331$.

Vanderwerff, L. M., L. F. Ferraretto, and R. D. Shaver. 2015. Brown midrib corn shredlage in diets for high-producing dairy cows. J. Dairy Sci. 98:5642-5652.

Vlaeminck, B., V. Fievez, A. R. J. Cabrita, A. J. M. Fonseca, and R. J. Dewhurst. 2006. Factors affecting odd- and branched-chain fatty acids in milk: A review. Anim. Feed Sci. Technol. 131:389-417.

Vlaeminck, B., V. Fievez, , H. van Laar, and D. Demeyer. 2004. Prediction of rumen volatile fatty acid proportions produced in vitro using variations in rumen odd and branched chain fatty acids. J. Anim. Physiol. Anim. Nutr. 88:401-411.

Weatherburn, M. W. 1967. Phenol-hypochlorite reaction for determination of ammonia. Analytical Chemistry 39:971-974.

Weissbach, F. 2009. Correction of dry matter content of silages used as substrate for biogas production.Pages 483-484 in Proceedings of the 15th International Silage Conference, US Dairy Forage Research Center, Madison, WI.

Wildman, E. E., G. M. Jones, P. E. Wagner, R. L. Boman, H. F. Troutt, and T. N. Lesch. 1982. A dairy-cow body condition scoring system and its relationship to selected production characteristics. J. Dairy Sci. 65:495-501. 
Wiles, P. G., I. K. Gray, and R. C. Kissling. 1998. Routine analyses of protein by Kjeldahl and Dumas methods: Review and inter-laboratory study using dairy products. J. AOAC Int. 81:620-632.

Wilkinson, J. M., and Rinne, M. 2018. Review: Highlights of progress in silage conservation and future perspectives. Grass and Forage Science 73:40-52.

Zebeli, Q., J. R. Aschenbach, M.Tafaj, J. Boguhn, B. N. Ametaj, and W. Drochner. 2012. Invited review: role of physically effective fiber and estimation of dietary fiber adequacy in high-producing dairy cattle. J. Dairy Sci. 95:1041-1056.

Zebeli, Q., and E. Humer. 2017. An update of particle size and effective NDF in maize silage-based rations. In: Proc. V International Symposium on Forage Quality and Conservation, Piracicaba, SP, Brazil, p. 21-39. 